University of Rhode Island

DigitalCommons@URI

Open Access Master's Theses

1985

\title{
The Growing Elderly Population and its Affect on the Demand for Subsidized Housing in Connecticut's Capital Region
}

Paul M. Sebestyen

University of Rhode Island

Follow this and additional works at: https://digitalcommons.uri.edu/theses

\section{Recommended Citation}

Sebestyen, Paul M., "The Growing Elderly Population and its Affect on the Demand for Subsidized Housing in Connecticut's Capital Region" (1985). Open Access Master's Theses. Paper 620.

https://digitalcommons.uri.edu/theses/620

This Thesis is brought to you for free and open access by DigitalCommons@URI. It has been accepted for inclusion in Open Access Master's Theses by an authorized administrator of DigitalCommons@URI. For more information, please contact digitalcommons-group@uri.edu. 
"THE GROWING ELDERLY POPULATION AND ITS AFFECT ON THE DEMAND FOR SUBSIDIZED HOUSING IN CONNECTICUT'S CAPITAL REGION"

PAUL M. SEBESTYEN $12 / 15 / 85$ 


\section{MASTER OF COMMUNITY PLANNING \\ RESEARCH PROTECT OF \\ PAUL M. SEBESTYEN}

APPROUED:

\section{MAJOR PROFESSOR}

MARCIA FELD

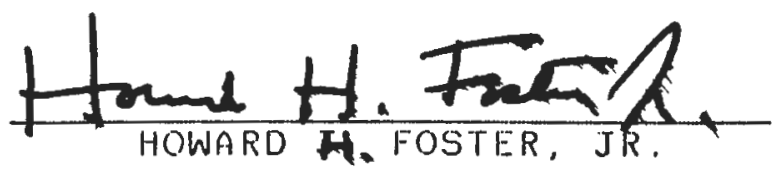


CHAPTER 1

DEMOGRAPHIC ANALYSIS

CONNEC.TIC.UT

CONNECTICUT'S ELDERLY POPULATION: OUERUIEW REGIONAL COMPARISON

DETAILED ANALYSIS OF CONNECTICUT'S ELDERLY POPULATION CONCLUSION

CAPITAL REGION US. THE STATE OF CONNECTICUT

CAPITOL REGION'S ELDERLY POPULATION: OUERUIEW

CAPITAL REGION'S POPULATION PROJECTIONS FOR THOSE CONCLLUSION

\section{CAPITAL REGION}

DETAILED ANALYSIS OF THE 65+ POPULATION WITHIN THE CITTES AND TOWNS OF THE CAPITOL REGION

POPULATION PROJECTIONS FOR THOSE PERSONS $65+$ FOR EACH CAPITAL REGION COMMUNITY

\section{CHAPTER 2}

SUBSIDIZED HOUSING OPPORTUNITIES FOR THE ELDERLY OF THE

CAPITOL REGION

GOUERNMENT :ASSISTED LOW AND MODERATE

INCOME HOUSING DEUELOPMENTS

COMPOSITION

ELIGIBILITY

COST

DISTRIBUTION 
CHAPTER 3

PRESENT AND FUTURE NEEDS FOR SUBSIDIZED ELDERLY HOUSING

IN THE CAPITOL REGION

PRESENT NEED

60

FUTURE NEED

66

CONCLUSION

CONCLUSION

APPENDIX A - CONNECTICUT'S OFFICE OF POLICY AND MANAGEMENT'S POPULATION PROJECTION METHODOLOGY

APPENDIX B - CONNECTICUT'S DEPARTMENT OF HEALTH SERUICES' ELDERLY PROJECTION METHODOLOGY

APPENDIX C - CONNECTICUT'S DEPARTMENT OF HEALTH SERUICES' ELDERLY PROJECTION METHODOLOGY FOR THE CAPITAL REGION

END NOTES

WORKS CITED

OTHER RESOURCES 
Number of Elderly Persons within the cities and Towns of the Capitol Region

Percentage of Elderly Persons within the cities and Towns of the Capitol Region

Elderly Population Growth (\%change 1980 - 2000) within the cities and Towns of the Capitol Region

The Capitol Region Cities and Towns with Governinent Assisted Low and Moderate Income Housing Developments for the Elderly

The Capitol. Region's Distribution of Elderly Units (\%) by Type of Community

The Distribution of Elderly 1 Bedroom Units

The Distribution of Elderly Efficiency Units

The Distribution of Elderly 2 Bedroom Units

The Distribution of Elderly 3 Bedroom Units

The Distribution of Elderly 4 Bedroom Units

The Distribution of Elderly Handicapped Accessible Units

14 Towns Participating in the Section 8 Rental Assistance Program

15 Cities and Towns with Elderly Median Fanily Incomes Below the Region

16 Cities and Towns Having $50.0 \%$ of their Elderly

Families with Incomes Bellow $\$ 15,000$

17 Elderly Population Growth in the Capitol Region $(1985-2000)$ 


\section{LIST OF TABLES}

TABLE

PAGE

1 Connecticut's Elderly Population from 1900-2000

2. Connecticut's Elderly Population Projections to 1990

Regional Comparison of Connecticut's Elderly

Population

Connecticut's Median Age as Compared to the U.S. and the New England States

Comparison of connecticut's 55-64. Population to the U.S. and other New England States

Connecticut's Elderly Population by Sex from $1990-1980$

Connecticut's Elderly Population by Sex by Cohorts

$(65-74,75-84,85+)$ for 1950, 1960, 1970, 1980

Connecticut's 65+ Population by Race (1950, 1900, 1970,1980 )

Capitol. Region's and state of Connecticut's 65t Population 1960, 1970, 1980

The Elderly as a Percentage of the Total Population of the Capitol Region and the state of connecticut

for $1900,1970,1980$

11 The Capitol Region and the state of connecticut's 1980 Elderly Population by Cohorts (65-74., 75-84, and $85+$ )

The Capitol Region and the state of Connecticut's

$65+$ Population by Sex for 1960, 1970, 1980

The Capitol Region and the state of Connecticut's 1980 Elderly Population by Sex and by Age Cohort

The Capitol Region and the State of Connecticut's Elderly population by Race for 1970 and 1980 
TABLE

PAGE

15 Population Projections for the capito. Region and the State of Connecticut from 1985 to 2000

16 Population Projections for the Capitol Region's Elderly ( 1985 to 2000)

17 Median Age of the Capitol Region's Cities and Towns

$18 \quad 1980$ Elderly Population for those Cities and Towns within the Capitol Region

1980 Elderly population by Sex for those Cities and Towns within the Capitol Region

1980 Elderly Population by Race for those Cities

21 Elderly Population Projections for each Capitol

Region City and Town ( 1985 to 2000)

22 The Capitol Region's Government Assisted Low and Moderate Income Elderly Housing Developments

23 Composition of the Capitol Region's Elderly Housing Units

24 Income Limits for the Section 8 Rental Assistance Program

1985 Fair Market Rents for the Section 8 Rental Assistant Program

Capitol Region's Section 8 Participants

27 Households Seeking Rental Assistance in the Section 8 Program in Connecticut

28 New Low and Modérate Income Housing Developments for the Elderly in the Capitol Region 


\section{LIST OF TABLES}

TABLE

30

31
The Capitol Region's Elderly Families by Income

1985 Elderly Subsidized Units as a Percentage of the Capitol Region, 1985 Towns Percentage of the Capitol. Region's Elderly, and 1985 - 2000 Elderly within the capitol Rogion
PAGE 


\section{INTRODUCTION}

The rapid expansion in the number of persons aged 65 and over is truely one of the most significant demographic trends currently affecting the state of connecticut and, more specifically, the Canitol Region isifined as the city of Hartford and the surrounding 28 cities and towns). Careful analysis of the explosive growth of elderly indiuiduals in the Capitol Region profiles a rising number of elderly as poor, on fixed incomes, and are increasely more apt to be women and minorities. The elderly's economic condition, combined with federal funding cuts in housing subsidies, social security benefits, food stamps, community care and transportation programs, as forced very real hardships on an ever-growing number of elderly indiuiduals and diminished their ability to afford housing within the Capitol Region. This lack of "subsidized" housing for the multitude of low and moderate income elderly will be one of the "major" issues confronting the Capitol Region's socio-economic community over the next 15 years. This paper will address this issue by demonstrating conclusively that the Capitol Region has not met the current demand by its elderly residents for subsidized housing, nor is it prepared to meet the sizeable dernand for these units in the future. 


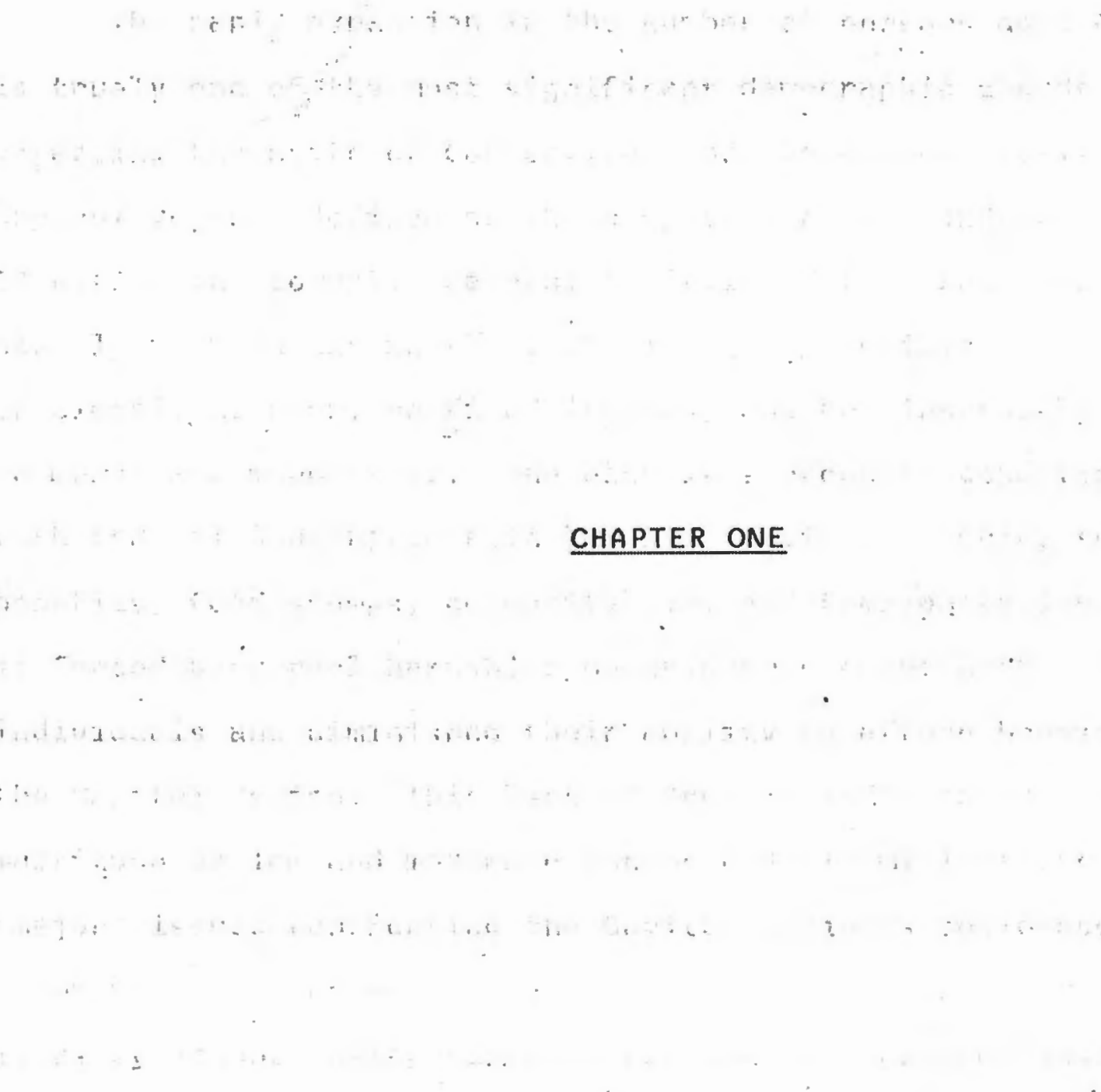


CONNECTICUT'S ELDERLY POPULATION: OUERUIEW

Connecticut's elderly population has consistently increased since 1920, when approximately 68,517 men and women, representing $4.9 \%$ of the State's total population were aged 65 years and over. By 1960 this elderly population had more than tripled, equalling 242,615 persons representing $9.5 \%$ of the state's total population; and by 1970 it had grown to 288,908 persons, though remaining at $9.5 \%$ of Connecticut's total population. But in no decade since 1920 has Connecticut's elderly population grown faster than during that period between 1970 and 1980. (See Table 1.) The 1980 U.S. Census shows that during the $1970^{\prime}$ s an additional 75,956 persons reached the age of 65 , brining connecticut's 65 years-and-over population to 364,864 persons, representing $11.74 \%$ of the state's total population. (See Table 1.)

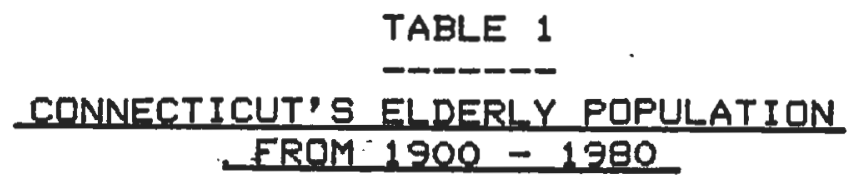

\begin{tabular}{|c|c|c|c|}
\hline YEAR & $\begin{array}{r}\text { CT. TOTAL } \\
\text {... POPULATION }\end{array}$ & $\begin{array}{r}\text { PERSONS } \\
65+\end{array}$ & $\begin{array}{l}\text { PERSQNS 65+ } \\
\text { AS A } \% \text { QF CT. } \\
\text { TOTAL PQP. }\end{array}$ \\
\hline 1900 & 908,420 & 50,850 & $(5.59)$ \\
\hline 1910 & $1,114,756$ & 59,588 & $(5.34)$ \\
\hline 1920 & $1,380,631$ & 68,517 & $(4.96)$ \\
\hline 1930 & $1,606,903$ & 93,319 & $(5.80)$ \\
\hline 1940 & $1,709,242$ & 128,554 & $(7.52)$ \\
\hline 1950 & $2,007,280$ & 176,824 & $(8.80)$ \\
\hline 1960 & $2,535,234$ & 242,615 & $(9.56)$ \\
\hline 1970 & $3,031,709$ & 288,908 & $(9.52)$ \\
\hline 1980 & $3,107,576$ & 364,864 & $(11.74)$ \\
\hline
\end{tabular}

SOURCE:U.S.CENSUS OF CONNECTICUT 1900 TO $1980-$ GENERAL POPULATION CHARACTERISTICS 
Though the number of elderly persons has always been growing, (i.e., in 1860 there were about 16 elderly people per 100 children (under 15 years of age), and by 1980 there were almost 54 elderly pacple per 100 children) the aging of connecticut's total population has been a more recent phenomenon, occurring primarily in the last 60 years. 1 prior to 1920 , changing trends in internal and international migration, as well as changes in fertility, caused the number of elderly as a percentage of Connecticut's total population to fluxuate. As shown in Table 1, the percentage of elderly in the State actually decreased from 1900 to 1920 . In fact, connecticut's 1920 percentage of $4.9 \%$ elderly represented a decline to it's 1860 level." since 1920 the elderly population has increased $432.5 \%$, which is much greater than that of Connecticut's total population, which only increased $125 \%$.

Several factors have contributed to the rapid expansion of Connecticut's elderly population since 1920. Perhaps the most important factor was the high fertility ratio between 1890 and the mid-1920's. This high fertility ratio, coupled with high levels of immigration from Europe that saw many predominately young immigrants settle in connecticut, Ied to a great rise in the number of births. This occurred until. 1925 when restrictive legislation brought about a sharp decline in immigration. It is these births which occurred between 1890 and the mid-1920's that are reflected in the continually increasing numbers of persons reaching the elderly stage of the life cycle. 
A decline in mortality is another factor which has contributed significantly to the aging of Connecticut's population." Most of the increase in the number of births in the first half of this century is attributable to tho reduction of the mortality risk of infectious disease, and to reductions in infant and maternal mortality. Recent increases in life expectancy, on the other hand, are due to reductions in mortality associated with chronic diseases. 3 These reductions in mortality have increased the average connecticut resident's life expectancy so that a person born in the state in 1980 can expect to reach the age of 75. This represents an increase of 2.5 years. from Connecticut's 1970 life expectancy of 72.5 years. In addition, future declines in mortality due to new advances in medical technology may increase the number of elderly persons in Connecticut.

These factors, coupled with early retirements, better nutrition, and changing life styles have allowed more connecticut residents than ever before to live longer, and this trend is projected to continue.

The unofficial Connecticut Department of Health Services projections, which used two methods based on 1980 mortality rates and 1970 to 1980 census trends for each age group, clearly indicates the 65 and over population in connecticut will continue to increase through the 1980's. The projection presented in Table 2 illustrate that Connecticut's 65 and over population will grow to 471,110 persons by 1990, resulting in an increase of 106,246 persons or $29.1 \%$. Of those age categories presented, the 75-79 age bracket 
shows the greatest increase $(29,414$ persons or $45 \%)$ between 1980 and 1990, with 70-74 (34,291 persons or 37\%) and 80-84 (15,750 persons or $36 \%$ ) closely behind. "After 1990, however, the Bureau of Census projects a changed'pattern of growth. The rate of increase in the elderly population between 1990 and 2010 will be slower than in the previous decade." 4 This is clearly dericted in the projected 1990 60-64 age bracket which shows an increase of only 6 persons between 1980 and 1990 , and 65-69 age bracket which shows only a modest increase of 24,284 persons, $19 \%$ during the same time period.

TABLE 2

CONNECTICUT'S ELDERLY POPULATION

PROJECTIONS TO 1990

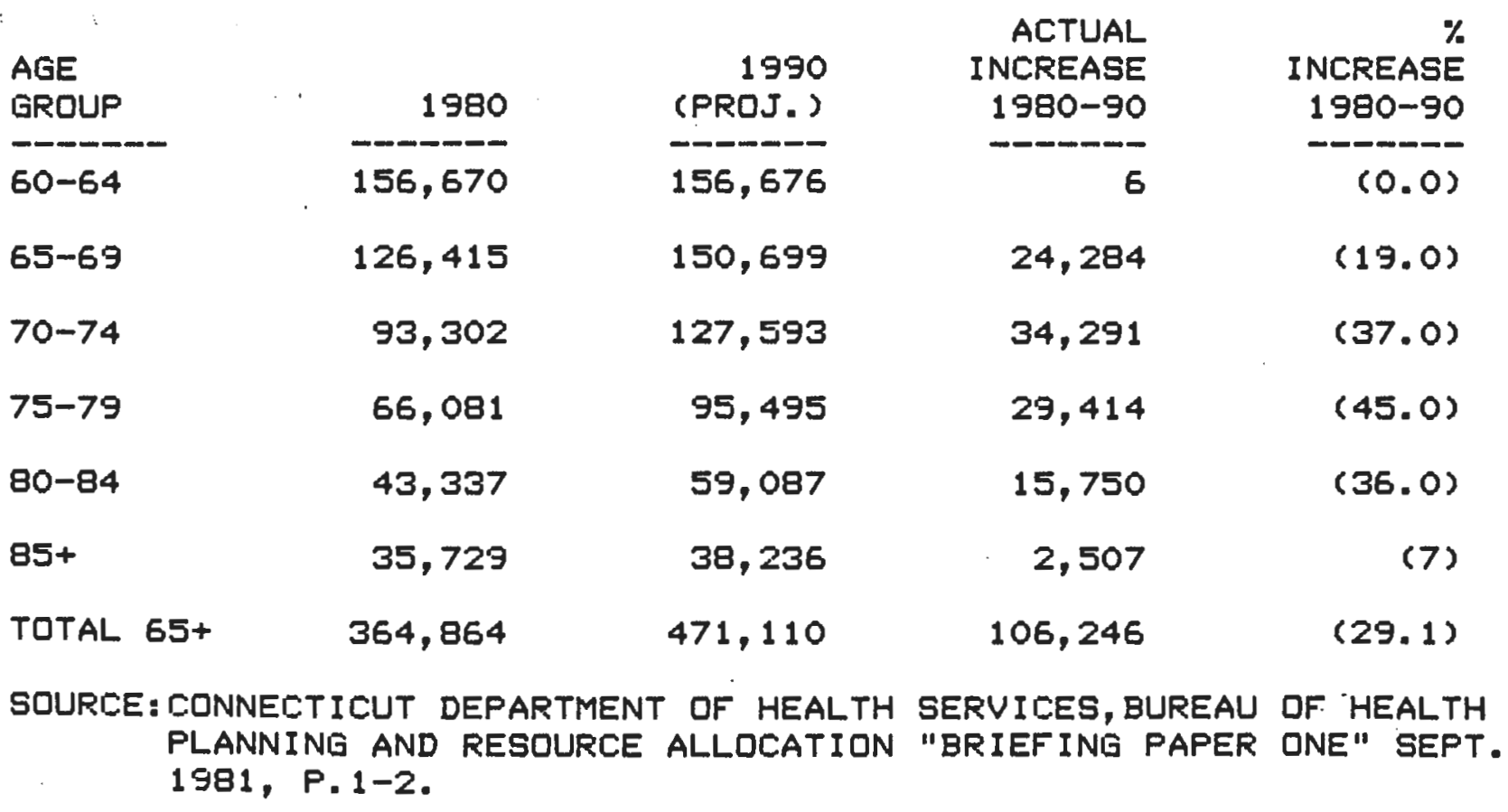


The aging of Connecticut's population is not an isolated phenomenon, but is characteristic of New England and the United States in general. The 1980 census data on population shows the nation, and especially New England, to have a sizeable portion of their population aged 65 years or older. In $1980,12.3 \%$ or $1,520,368$ persons out of New England's total population of $12,348,493$, and $11,3 \%$ or $25,544,133$ persons out of the United States' total population of $226,502,825$ persons were aged 65 years or older. (See Table 3.)

A comparison of the 1980 median age of New England with that of the nation indicates that New England's population is somewhat older. In 1980, the median age for New England was 31.2 years. This median age is a full 1.2 years older than the United States' median age of 30.0 years. When the median age for each New England state is compared to the nation's median age. it is found that every state except vermont has a median age above the national

TABLE 3

-.--.-.

REGIOHAL COAPARISON OF CONNECTICUT'S ELDERLY POPULATION

\begin{tabular}{|c|c|c|c|c|c|}
\hline & $\begin{array}{r}\text { TOTAL } \\
\text { POPULATION }\end{array}$ & $\begin{array}{r}\text { PERSONS } \\
65+\end{array}$ & $\begin{array}{c}65+\text { AS } \\
\text { y OF } \\
\text { TOT. } \\
\text { POP. }\end{array}$ & RANK & $\begin{array}{r}\text { Z OF } \\
\text { N.E. } \\
\text { TOTAL } \\
65+\end{array}$ \\
\hline U.S. & $226,504,825$ & $25,544,133$ & 11.3 & & \\
\hline NEW ENGLAND & $12,348,493$ & $1,520,368$ & 12.3 & & \\
\hline He. & $1,124,660$ & 140,918 & 12.5 & $3 R D$ & 9.3 \\
\hline К. H. & 920,610 & 102,967 & 11.2 & БТH & 6.8 \\
\hline Vt. & 511,456 & 58,166 & 11.4 & 5TH & 3.8 \\
\hline Mass. & $5,737,037$ & 726,531 & 12.7 & 2ND & 47.8 \\
\hline R.I. & 947,154 & 126,922 & 13.4 & 1ST & 8.3 \\
\hline Ct. & $3,107,576$ & 364,864 & 11.7 & 4TH & 24.0 \\
\hline
\end{tabular}


figure, with Connecticut's median age being the highest. According to the 1980 census, Connecticut's population had a median age of 32.0 years, which is a 2 full years above the national figure. This represents an increase of 2.9 years from connecticut's 1970 median age of 29.1 years. (See Table 4.)

In 1:30, the State of Connecticut had 364,864 persons 65 years of age and over, accounting for $24 \%$ of New England's total elderly population. This was second only to Massachusetts' $47.8 \%(726,531$ persons) aged 65 and over. Though connecticut has a significant portion of New England's elderly population, it has a smaller proportion of it's population in the $65+$ age category, placing only 4th out of the six New England states. (See Table 3.) When comparing each New England state's proportion of persons 65 years and over with the national figure of $11.3 \%$ elderly, one finds every state in New England, except New Hampshire, to have a larger proportion of its population in the elderly category. (See Table 3.)

TABLE 4

\section{CONNECTICUT'S MEDIAN AGE AS COMPARED TO THE U.S.} AND NEW ENGLAND STATES

$\begin{array}{lrr} & \text { MEDIAN AGE } & \text { RANKING } \\ \text { UNI TED STATES } & 30.0 & \\ \text { NEW ENGLAND } & 31.2 & \\ \text { MAINE } & 30.4 & \text { 4TH } \\ \text { NEW HAMPSHIRE } & 30.1 & \text { 5TH } \\ \text { VERMONT } & 29.4 & \text { 6TH } \\ \text { MASSACHUSETTS } & 31.2 & \text { 3RD } \\ \text { RHODE ISLAND } & 31.8 & \text { 2ND } \\ \text { CONNECTICUT } & 32.0 & \text { 1ST }\end{array}$

SOURCE: CONNECTICUT CENSUS DATA CENTER, MEMORANDUM NO.5, JUNE 1, 1981 FROM U.S. BUREAL OF THE CENSUS PC8O-S1-1 (MAY 1981). 
One last point should be made in comparing Connecticut's elderly population with that of the other New England states: an analysis of Connecticut's 55-59 and 60--64 age categories shows the State in 1980 to have a large proportion of its population between the ages of 55 and 64 ( $10.8 \%$ or 335,382 persons). When Connecticut's 5-Ei rupulation is compared $t=$ the nation and the other New England states, one finds Connecticut's porportion to be significantly greater than the national figure of $9.6 \%$; regionally (New England) it is second only to Rhode Island's $11.1 \%$.

Consequently, Connecticut's relatively high proportion of its 1980 population between the ages of 55 and 64 will result in a substantial increase in its 65 years and over population beginning in 1985. (See Table 5.)

TABLE J

TABLE

COMPARISON OF CONNECIICUTS 55-64 POPULATION TO THE U.S. AND. OTHER NEW ENGLAND STATES

\begin{tabular}{|c|c|c|c|c|c|}
\hline & $\begin{array}{r}\text { TOTAL } \\
\text { POPULATION }\end{array}$ & $\begin{array}{l}55-59 \\
\text { YEARS }\end{array}$ & $\begin{array}{l}60-64 \\
\text { YEARS }\end{array}$ & $\begin{array}{l}\text { TOTAL } \\
\text { S5-64 } \\
\text { YEARS }\end{array}$ & $\begin{array}{r}55-64 \\
\% \text { OF } \\
\text { TOTAL } \\
\text { POP. }\end{array}$ \\
\hline บ.S. & $226,504,825$ & $11,614,054$ & $10,085,711$ & $21,699,765$ & 9.6 \\
\hline Me. & $1,124,650$ & 56,566 & 50,811 & 107,377 & 9.5 \\
\hline N.H. & 920,610 & 44,749 & 39,677 & 84,426 & 9.2 \\
\hline Vt. & 511,456 & 23,502 & 21,023 & 44,525 & 8.7 \\
\hline Mase. & $5,737,037$ & 310,995 & 277,384 & 588,379 & 10.3 \\
\hline R.I. & 947,154 & 55,748 & 49,451 & 105,199 & 11.1 \\
\hline ct. & $3,107,576$ & 178,712 & 156,670 & 335,382 & $10.8^{\circ}$ \\
\hline
\end{tabular}


Analysis of Connecticut's elderly population has revealed a number of significant demographic patterns. First, connecticut's 1980 census data for persons 65 years or age of older shows females significantly outnumbering males. Historically, there have always been more femazse Lhan males in connecticut's elderly population. What has been significant is the increase in the proportion of $65+$ female population over the last 40 years. From 1900 to 1950 . approximately $54 \%$ of Connecticut's elderly population was female. Starting in 1950, this proportion has increased to where in 1980 , $61 \%$ of the state's 65 and over population was female. (See Table 6.)

Not only has the proportion of females increased for Connecticut's entire elderly population, but one also finds that within each age bracket $(65-74,75-84$, and $85+)$ the female proportion increases and that this increase has risen significantly

TABLE 6

\section{CONNECTICUT' ELDERLY POPULATION BY SEX FROM}

$$
1900-1980
$$

\begin{tabular}{lrrrrr} 
TETAL 65+ & $\begin{array}{r}\text { TOTR } \\
\text { POPULATION }\end{array}$ & MALE & $\%$ & FEMALE & $\%$ \\
\hline 1900 & $-10,850$ & 23,333 & $(46)$ & 27,517 & $(54)$ \\
1910 & 59,588 & 27,541 & $(46)$ & 32,047 & $(54)$ \\
1920 & 68,517 & 31,547 & $(46)$ & 36,970 & $(54)$ \\
1930 & 93,319 & 43,507 & $(47)$ & 49,812 & $(53)$ \\
1940 & 128,554 & 59,313 & $(46)$ & 69,241 & $(54)$ \\
1950 & 176,824 & 80,387 & $(45)$ & 96,437 & $(55)$ \\
1960 & 242,615 & 107,210 & $(44)$ & 135,405 & $(56)$ \\
1970 & 288,908 & 116,794 & $(40)$ & 172,114 & $-(60)$ \\
1980 & 364,864 & 143,515 & $(39)$ & 221,349 & $(61)$
\end{tabular}

SOURCE:U.S. CENSUS FOR CONNECTICUT 1900-1980. 
1950. Table 7 illustrates that in Connecticut in 1950, females represented $53 \%$ of those persons $65-74,57 \%$ of those persons $75-84$, and $63 \%$ of those persons 85 and over. By 1980 this female proportion had increased to $57 \%$ of the $65-74$ bracket, $65 \%$ of the 75-84 bracket, and $71 \%$ of the 85 and older age bracket.

Secondz;. Fiore ron-white individuals are beginning to enter Connecticut's elderly population. Accordingly to census figures, in 1950 only $1.4 \%$ of Connecticut's elderly population were non-white. Over the next 30 years this proportion of 65 and over non-white individuals increased to $1.9 \%$ by $1960,2.9 \%$ by 1970 and finally accounted for $3.7 \%$ by 1980 . (See Table 8. )

TABLE 7

CONMECTICUT'S ELDERLY POPULATION BY SEX BY COHORTS $(65-74,75-84,85+)$

FOR 1950, 1960, 1970, 1980

\begin{tabular}{|c|c|c|c|c|c|c|c|c|}
\hline \multirow[b]{2}{*}{ MALE } & 1950 & $\begin{array}{r}l \\
\text { OF AGE } \\
\text { BRACKET }\end{array}$ & 1960 & $\begin{array}{r}\text { Z } \\
\text { OF AGE } \\
\text { BRACKET }\end{array}$ & 1970 & $\begin{array}{l}\text { OF AGE } \\
\text { BRACKET }\end{array}$ & 1980 & $\begin{array}{l}\text { OF AGE } \\
\text { BRACKET }\end{array}$ \\
\hline & & & & & & & & \\
\hline $65-74$ & 56,483 & & 74,564 & & 73,863 & & 94,818 & \\
\hline $75-84$ & 20,633 & & 27,497 & & 35,246 & & 38,384 & \\
\hline $85+$ & 3,271 & & 5,149 & & 7,685 & & 10,313 & \\
\hline
\end{tabular}

FEMALES

$\begin{array}{rrrrrrrrr}65-74 & 63,741 & (53) & 88,359 & (54) & 100,947 & (58) & 124,899 & (57) \\ 75-84 & 27,188 & (57) & 39,108 & (58) & 56,430 & (62) & 71,034 & (65) \\ 85+ & 5,508 & (63) & 8,938 & (63) & 14,737 & (66) & 25,416 & (71) \\ \text { TOTAL } & 176,824 & & 242,615 & & 288,908 & & 364,864 & \end{array}$

SOURCE:U.S. CENSUS FOR CONNECTICUT 1950, 1960, 1970, AND 1980. 
A breakdown of the non-white population shows blacks accounting for the greatest proportion of this population. In $1970,87 \%(2.5 \%$ of the total $65+$ population-all races) of Connecticut's $65+$ non-white population was black, and in $1980,80 \%$ ( $3.0 \%$ of the total $65+$ population-all races) of the $65+$ non-white population was black. It should bo nat:i silat even though blacks accounted for the majority of Connecticut's non-white elderly population, increasing $52 \%$ between 1970 and 1980 (white elderly only increased 25\%), the numbers of 'Other' 65 and over minority individuals (those not black or white) have substantially increased (See Table 8). Between 1970 and 1980, Connecticut's 65 and older 'Other' population increased $147 \%$, rising from .4\% (1970) to. $7 \%$ (1980) of the state's total elderly population. This 'other' elderly population may represent an even greater proportion or larger share of the non-white elderly population in the future.

One of the major reason why non-whites (especially blacks) are representing a greater proportion of Connecticut's elderly is due to changes in early mortality patterns. "These changes have meant fewer non-whites (especially black males) are dying at earlier ages than in the past." 5

\section{TABLE 8}

CONYECTICUT'S 65+ POPULATION BY RACE

$$
(1950,1960,1970,1980)
$$

\begin{tabular}{|c|c|c|c|c|c|c|c|c|}
\hline RACE & 1950 & $\begin{array}{l}7 \text { OF } \\
\text { TOTAL } \\
65+\end{array}$ & 1960 & $\begin{array}{l}7 \text { of } \\
\text { TOTAL } \\
65+\end{array}$ & 1970 & $\begin{array}{l}7 \text { Of } \\
\text { TOTAL } \\
65+\end{array}$ & 1980 & $\begin{array}{l}7 \text { OF } \\
\text { TOTAL } \\
65+\end{array}$ \\
\hline-- & - & --.- & ---"--"- & -.... & -------- & -..... & --_-_-_- & -.... \\
\hline UHITE & 174,219 & & 238,082 & & 280,512 & & 351,041 & \\
\hline NON-WHITE & 2,605 & (1.4) & 4,533 & (1.9) & 8,396 & (2.9) & 13,823 & (3.7) \\
\hline BLACK & $M$ & & $M$ & & 7,310 & $(2.5)$ & 11,138 & $(3.0)$ \\
\hline OTHER & MA & & MA & & 1,086 & $(.4)$ & 2,685 & $(.7)$ \\
\hline TOTAL $65+$ & 176,824 & & 242,615 & & 288,908 & & 364,864 & \\
\hline
\end{tabular}


In conclusion:

* Connecticut's 65 years and over population has grown significantly since 1920 .

* Connecticut's 65 years and over population will continue to increase until 1990, when this rate of increase will slow until 2010.

* The aging of connecticut's population is not an isolated phenomenon, but is characteristic of New England and the United States in general.

* Connecticut's population is somewhat older than the other New England States and the Nation's.

* The State of connecticut contains the second largest elderly population in New England.

* Connecticut has a lower proportion of it's residents 65 and over than most of the other New England States.

* Connecticut has a substantial proportion of it's population between the ages of 55 and 64 which will begin to enter the 65 years and over age bracket in 1985 .

* Connecticut's elderly population has significantly more females than males.

* Connecticut's female to male ratio for those persons 65 years of age and over increases as the age brackets increase (females outnumbering males).

*More non-whites are beginning to enter connecticut's elderly population.

* And finally, Connecticut's elderly black and 'Other' minority population has grown considerably faster than Connecticut's white elderly population over the last 10 years. 
The Capitol Region is the largest of connecticut's 15 planning regions. Located in the northcentral portion of the state, the Capitol Region encompasses 29 towns with Hartford at its center. (See Map 1.) These towns cover slightly more than 750 square miles, and contain 668,479 persons, or $21.5 \%$ of connecticut's 1980 tota'! population.

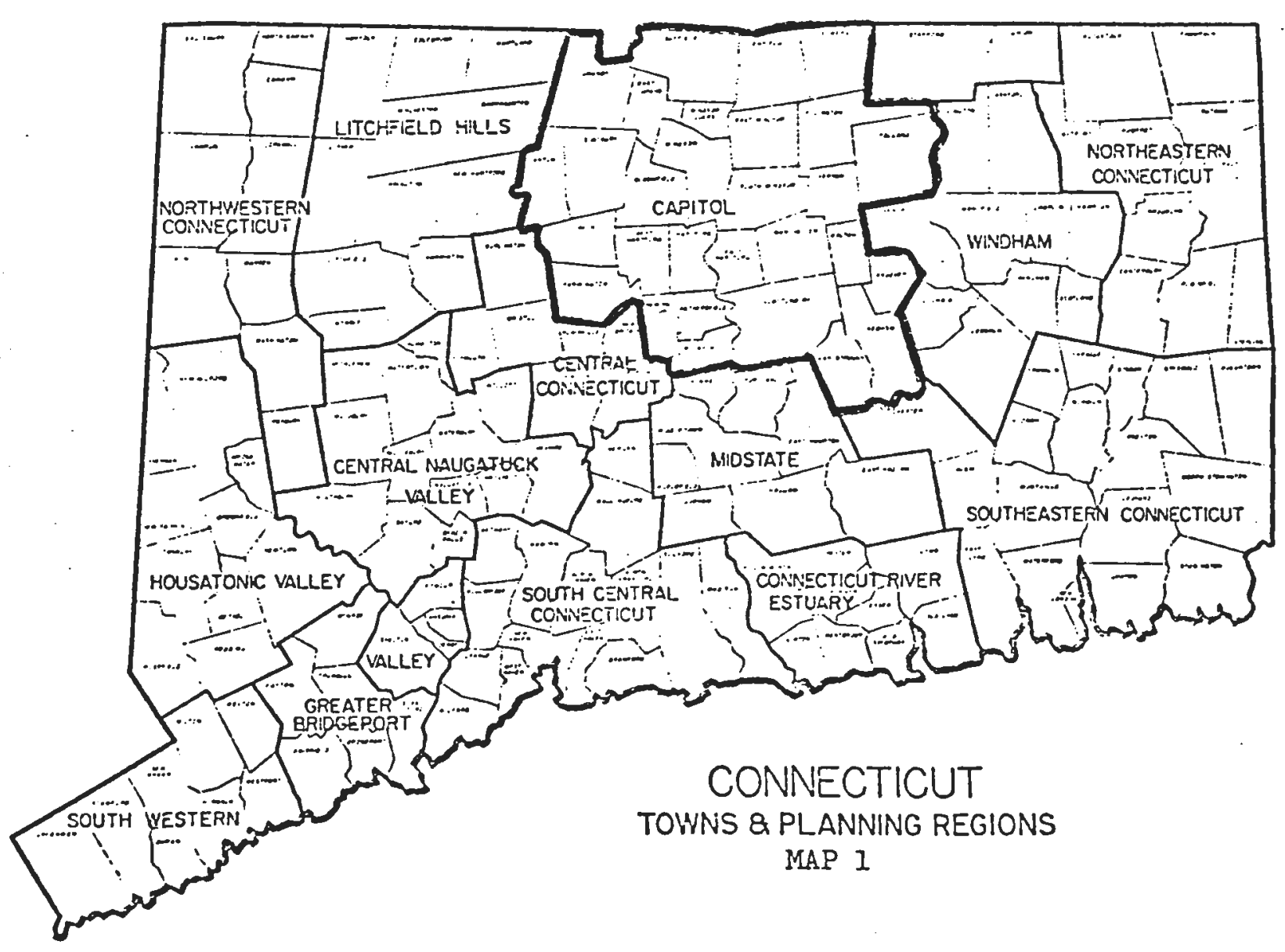


When the Captiol Region's population, especially its elderly population, is compared to the state of connecticut's population, one finds a number of similarities. First, the Capitol Region's population is one that is getting older. In 1980, the capitol Region's median age was 32.0 years, which equalled the state's. Tilis median age represented a full 3.3 years increase from the 1970 median age of 28.7 years, and was slightly greater than Connecticut's median age increase of 2.9 years from 1970 to 1980 .

Secondly, the Capitol Region's elderly population has increased over the last 30 years. In 1960 , the Capitol Region had 49,254 persons 65 years of age or older. By 1970, this population segment had grown to 61,002 persons and by 1980, 77,018 persons were elderly. This elderly growth represented an increase of $23.8 \%$ between 1960 and 1970. 26.2\% between 1970 and 1980 , and $56.3 \%$ over the 20 year period from 1960 tó 1980. This percentage increase in the Capitol Region's elderly population between 1970 and 1980 was exactly the same as the State's, although the Capitol Region's proportion of elderly persons grew at a greater rate $(0.0 \%)$ over the 20 year period. (See Table 9.)

TABLE 9

CAPITOL REGION'S AND STATE OF CONNECTICUT'S 65+ POPULATION 1960, 1970,1980

\begin{tabular}{|c|c|c|c|c|c|c|}
\hline & 1960 & 1970 & $\begin{array}{r}\% \text { INC. } \\
1960- \\
1970\end{array}$ & 1980 & $\begin{array}{r}\% \text { INC. } \\
1970- \\
1980\end{array}$ & $\begin{array}{r}\% \text { INC. } \\
1960- \\
1980\end{array}$ \\
\hline CAPITOL REGION & 49,245 & 61,002 & $(23.8)$ & 77,018 & $(26.2)$ & $(56.3)$ \\
\hline STATE OF CONNECTICUT & 242,615 & 288,908 & $(19.0)$ & 364,864 & $(26.2)$ & $(50.3)$ \\
\hline
\end{tabular}


Thirdly, one finds persons 65 years of age or older representing a greater proportion of the capitol Region's total. population. In 1960 , the elderly accounted for $9.0 \%$ of the Capitol Region's total population. By 1970, this proportion had grown to $9.1 \%$, and by $1980,11.5 \%$ of the Capitol Region's population was 65 years of age or clitar. (See Table 10.) When this proportional growth is compared to the increase of elderly persons in the .State's population, one finds the proportional increases to be quite similar. In $1960,9.5 \%$ of Connecticut's total population were elderly. By 1970 this population segment grew to $9.52 \%$, and then to $11.74 \%$ by 1980 . (See Table 10.)

\section{TABLE 10}

THE ELDERLY AS A PERCENTAGE OF THE TOTAL POPULATION OF THE CAPITOL REgION AMD THE STATE OF COMECTICUT FOR 1960,1970 , ANO 1980

\begin{tabular}{|c|c|c|c|c|c|c|c|c|c|}
\hline & TOTAL & & & TOTAL & & & TOTAL & & \\
\hline & POPULATION & 654 & 2 & POPULATION & $65 t$ & 7 & POPULATION & $65+$ & 2 \\
\hline$C R$ & 546,545 & 49,254 & $(9.00)$ & 669,907 & 61,002 & $(9.10)$ & 668,479 & 77,018 & $(11.50)$ \\
\hline ct. & $2,535,234$ & 242,615 & $(9.56)$ & $3,031,709$ & 288,908 & $(9.52)$ & $3,107,576$ & 364,864 & $(11.74)$ \\
\hline
\end{tabular}

Fourthly, when the Capitol Region's 1980 elderly population is broken into the age brackets $65-74,75-84$, and $85+$, one finds the proportion of persons within these brackets to be quite similar to that of the State of Connecticut's. In $1980,6.8 \%$ of the Capitol Region's total population of 668,479 persons were in the $65-74$ age bracket, $3.5 \%$ in the $75-84$ age bracket, and $1.17 \% 85$ years or older. (See Table 11.) The State of Connecticut in 1980 had $7.0 \%$ 
of its total population of $3,107,576$ persons between $65-74,3.5 \%$ between $75-84$ and $1.14 \% 85$ or over. When comparing just the total e]derly population within these age brackets, one finds in 1980 , $59.0 \%$ of the Capitol Region's elderly population of 77,018 persons were between $05-74,30.7 \%$ were between $75-84$, and $10.1 \%$ were $85+$. (See Table 11.) In the State of Connecticut, out of a 1980 elderly population of $364,864,60.2 \%$ were between $05-74,30.0 \%$ between $75-94$ and $9.8 \% 85$ years or older. (See Table 11.) Therefore, whether one compares proportions of the total population or total elderly population for the age brackets $65-74,75-84$, or $85+$, one finds the Capitol Region's and the state of Connecticut's proportions to be very much alike.

\section{TABLE 11}

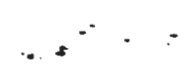

THE CAPITOL REGION AND THE STATE OF COMECTICUT'S 1980 ELDERLY POPULATION BY COHORTS (65-74, 75-84, AND 854)

\begin{tabular}{|c|c|c|c|c|c|c|c|c|c|c|c|}
\hline & $\begin{array}{c}\text { TOTAL } \\
\text { POPULATIOK }\end{array}$ & $\begin{array}{l}\text { TOT. } \\
\text { ELD. } \\
\text { POP. }\end{array}$ & $65-74$ & $\begin{array}{l}7 \\
\text { TOT. } \\
\text { POP. }\end{array}$ & $\begin{array}{l}7 \\
\text { ELD. } \\
\text { POP. }\end{array}$ & $75-84$ & $\begin{array}{l}7 \\
\text { TOT. } \\
\text { POP. }\end{array}$ & $\begin{array}{l}l \\
\text { ELD. } \\
\text { POP. }\end{array}$ & 854 & $\begin{array}{l}7 \\
\text { TOT. } \\
\text { POP. }\end{array}$ & $\begin{array}{l}8 \\
\text { ELO. } \\
\text { POP. }\end{array}$ \\
\hline$C R$ & $668,479$. & 77,018 & 45,478 & $(6.8)$ & $(59.0)$ & 23,687 & (3.5) & $(30.7)$ & 7,853 & $(1.17)$ & $(10.1)$ \\
\hline ct. & $3,107,576$ & 364,864 & 219,717 & $(7.0)$ & $(60.2)$ & 109,418 & (3.5) & $(30.0)$ & 35,729 & $(1.14)$ & $(9,8)$ \\
\hline
\end{tabular}

It should be noted that when comparing the Capitol Region's 55-64 population segment with that of the state's, one finds the proportion of persons within this age bracket to be very much the same. Analysis of the 1980 census data shows the Capitol Region to have $10.6 \%(70.925$ persons) of its population within the $54-64$ age 
bracket. During 1980 , the state of Connecticut had $10.7 \%(335,382$ persons) of its population between the ages of 55 and 64 . This means that over the next 10 years, the Capitol Region and the State of Connecticut will have approximately the same proportion of persons becoming 65 years of age or older. The actual increase of elderly persons will be discussed later in this section, where the Capitol Region's elderly population is projected to the year 2000.

Fifthly, analysis of the Capitol Region's elderly population shows females significantly outnumbering males, much like they did in the state. as a whole. In 1980, $61 \%$ of the Capitol Region's 65 years and over population was female. This represents a significant increase from $1960^{\prime}$ s elderly population, in which only $51.8 \%$ of the Capitol Region's elderly population was female. (See Table 12.) Over the same period of time (1960-1980), the State's proportion of females 05 and over increased from $55.8 \%$ in 1960 to $60.7 \%$ in 1980 . (See Table 12.)

TABLE 12

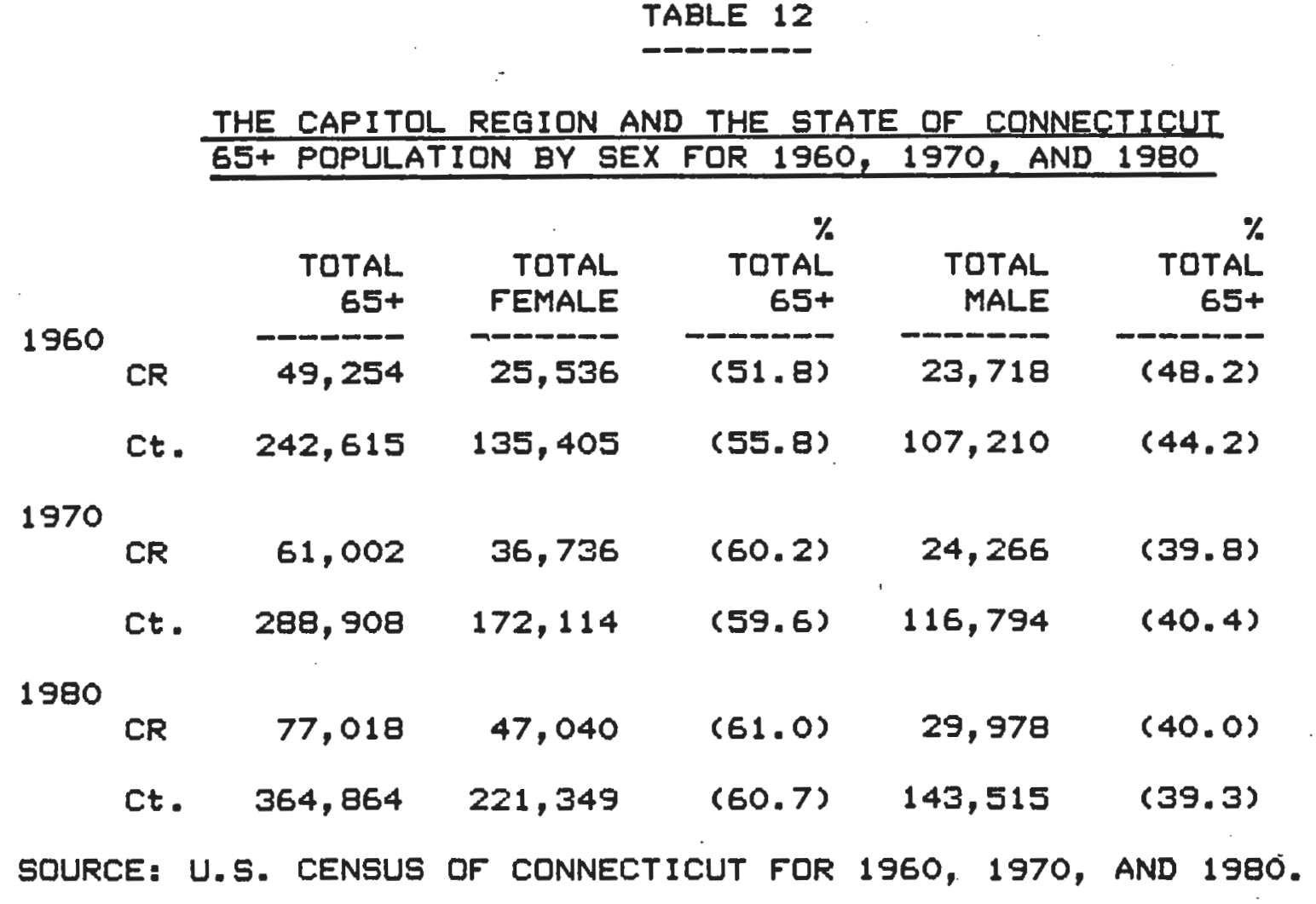


One also finds that with each increase in age bracket $(05-74$, 75-84, and 85+), the proportion of females to males within the Capitol Region increases. Table 13 shows that in the Capitol Region in 1980 , females represented $57.0 \%$ of those persons between the ages of 65 and $74,65.7 \%$ between 75 and 84 , and $71.0 \%$ of those persons 85 years of age or older. These 1980 proportions for the capitol Region are almost a mirror image of those for the state of connecticut.

TALE 13

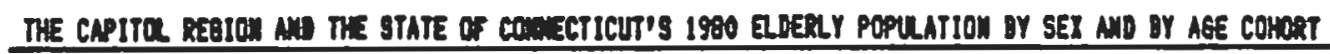

\begin{tabular}{|c|c|c|c|c|c|c|c|c|c|c|c|}
\hline & & ENME & & & & & & WLE & & & \\
\hline $65-74$ & $\begin{array}{c}2 \text { of } \\
\text { TOTM } \\
65-74\end{array}$ & $75-84$ & $\begin{array}{l}70 \\
\text { rork } \\
75-84\end{array}$ & $85+$ & $\begin{array}{c}20 \% \\
\text { ToTk } \\
\text { 8st }\end{array}$ & $65-74$ & $\begin{array}{c}20 \\
\text { TOTM } \\
65-74\end{array}$ & $75-84$ & $\begin{array}{l}7 \text { of } \\
\text { TOTM } \\
75-84\end{array}$ & $85+$ & $\begin{array}{c}\text { I of } \\
\text { TOTAL } \\
\text { 85+ }\end{array}$ \\
\hline 25,907 & $(57.0)$ & 15,591 & $(65.7)$ & 3,582 & (71.1) & 19,571 & $(43.0)$ & 8,136 & $(34.3)$ & 2,271 & $(28.9)$ \\
\hline Ct. . . 124,899 & $(56.9)$ & 71,034 & $(64.9)$ & 25,416 & $(71.1)$ & 94,818 & $(43.1)$ & 38.384 & $(35.1)$ & 10,313 & $(29.9)$ \\
\hline
\end{tabular}

Sixth and finally, one finds the proportion of non-whites among the Capitol Region's elderly population to be singificantly increasing. As shown in Table 14, in $1970,3.7 \%$ of the Capitol Region's elderly population were non-white ( $3.3 \%$ Black, .4\% other). By 1980 this porportion had increased to where non-whites represented $5.03 \%$ of those persons 65 years and older in the capitol Region. Comparing these proportional increases to those of the State's, one finds the capitol Region's non-white elderly population to have groun faster and represent more of those persons 65 years of age and over since 1970. (See Table 14.) 
THE CAPITO REGION AND THE STATE OF CONHECTICUT'S ELDERLY POPULATION BY RACE FOR 1970 AND 1980

65+ NON-WHITE

\begin{tabular}{|c|c|c|c|c|c|c|}
\hline \multirow[b]{3}{*}{$65+$} & \multirow{3}{*}{$\begin{array}{r}65+ \\
\text { WHITE }\end{array}$} & & \\
\hline & & & $\begin{array}{l}2 \text { of } \\
\text { TOTAL }\end{array}$ & & $\begin{array}{c}7 \text { OF } \\
\text { TOTAL }\end{array}$ & $\begin{array}{l}\text { NON-WHT. } \\
\text { AS } 2 \text { OF }\end{array}$ \\
\hline & & BLACK & $65+$ & OTHER & $65+$ & TOT. $65+$ \\
\hline
\end{tabular}

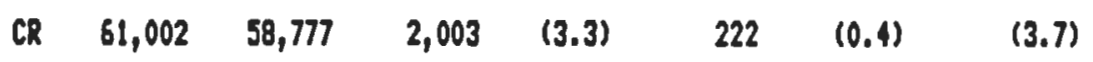

C.. $289,908 \quad 280,512 \quad 7,310 \quad(2.5) \quad 1,086 \quad(0.4) \quad(2.9)$

1980

$\begin{array}{lrrrrrrr}\text { CR } & 77,018 & 73,156 & 3,147 & (4.1) & 715 & (0.93) & (5.03) \\ \text { C.. } 364,864 & 351,041 & 11,138 & (3.0) & 2,685 & (0.70) & (3.7)\end{array}$

SOURCE:U.S. CENSUS OF CONECTICUT FOR 1970 AND 1980.

CAPITOL REGION'S POPULATION PROJECTIONS FOR THOSE PERSONS $65+$

According to population projections done by the state of Connecticut's office of Policy and Management in June of 1982, (see Appendix A for methodology), the Capitol Region's population is expected to increase $12.1 \%$ over the next two decades, reaching a total of 749,430 persons by the year 2000 . This projected growth is greater than that projected for the State of connecticut, which is only expected to increase $8.8 \%$ by the year 2000 . (See Table 15.)

A sizeable portion of the Capitol Region's projected population increase will be in persons aged 65 years or older. As indicated in the projections contained within Table 16, the Capitol Region's elderly population will increase to 94,733 persons by the year 2000. This represents an increase of $23.0 \%$ over the twenty year 
POPULATION PROJECTIONS FOR THE CAPITOL REGION AND THE STATE OF CONMECTICUT

$$
\text { FROH } 1980 \text { TO } 2000
$$

\begin{tabular}{|c|c|c|c|c|c|c|}
\hline & 1980 & 1985 & 1990 & 1995 & 2000 & $\begin{array}{l}2 \text { CHANGE } \\
\text { 1980-2000 }\end{array}$ \\
\hline$C R$ & 668,479 & 688,150 & 710,660 & 730,020 & 749,430 & $(12.1)$ \\
\hline & $3,107,576$ & $3,179,640$ & $3,358,230$ & $3,324,000$ & $3,379,980$ & $(8.8)$ \\
\hline
\end{tabular}

SOURCE:STATE OF COMMECTICUT OFFICE OF POLICY AND MAMAGEMENT, POPULATION PROJECTIONS FOR CONMECTICUT MUNICIPALITIES AND REGIONS TO THE

YEAR 2000. JUNE 1982. (SEE APPENDIX A FOR METHODOLOGY).

period. It should be noted that as mentioned previously ( $p .3)$, the rate of persons in Connecticut entering the 65 and over cohorts will slow between 1990 and the year 2010. This slowdown is reflected in the Capitol Region, and is primarily due to the changes in connecticut's distribution of population by age. As evidenced in Table 16 the Capitol Region's projected elderly rate of growth drops from $4.8 \%$ between 1990 and 1995 , to-.6\% from 1995 to the yer 2000.

\section{TABLE 16}

$-\infty-\infty-10$

POPULATIOY PROJECTIONS FOR THE CAPITOL REGION'S ELOERLY

(1980 T0 2000)

\begin{tabular}{|c|c|c|c|c|c|c|}
\hline & 1980 & 1985 & 1990 & 1995 & $\begin{array}{r}1990- \\
1995\end{array}$ & 2000 \\
\hline PITOL REGION & 77,018 & 84,591 & 92,231 & 95,358 & $(4.8)$ & 94,733 \\
\hline
\end{tabular}

SOURCE: CONMECTICUT DEPARTMENT OF HEALTH SERVICES MARCH 1979, HET 1528C. \$THE PROJECTIONS SHOLH IN THIS TABLE HERE ADJUSTED ACCORDING TO I980 CENSUS COUNTS. (SEE APPENDIX B FOR METHODOLOGY). 
* The Capitol Region is experiencing many of the same demographic changes, particularly in reference to the elderly, as the State of Connecticut.

* The Capitol Region's population is one that is getting older.

* The Capitol Region's elderly population has increased significantly over the last 30 vears.

* The proportion of elderly persons in the capitol. Region to the Region's total population has increased significantly over the last 30 years.

*Most of the Capitol Region's 1980 elderly population is found in the 65 to 74 age cohort.

* The Capitol Region in 1980 had a significant proportion of its population between the ages of 55 and 64 . These people will begin entering the elderly cohorts in 1985 .

* Females significantly outnumber males in the Capitol Region's 1980 elderly population, and this differential has increased over the last 20 years.

* The proportion of elderly females to elderly males in the Capitol Region in 1980 has increased significantiy with each rising elderly cohort (65-74, 75-84, and 85+), with fernales outnumbering males.

* The proportion of non-white elderly persons among the Capitol Region's elderly population has significantly increased since 1970 .

* A sizeable porportion ( $23.0 \%$ ) of the Capitol Region's projected population growth of $12.1 \%$ over the next two decades will be in persons aged 65 years or older. 


\section{THE CAPITOL REGION}

The Capitol Region is comprised of a combination of 29 urban, suburban and rural communities. ni the center of the Region lies the city of Hartford, which is surrounded by the inner core towns of East Hartford. Manchester, and West Hartford. Beyond the inner core lie the inner and outer suburbs. The towns contained within the inner suburbs are Bloomfield, Glastonbury, Newington, South windsor, Wethersfield, and windsor. Those towns located within the outer-suburbs are Andover, Avon, Bolton, Canton, East Granby, East Windsor, Ellington, Enfield, Farmington, Granby, Hebron, Marlborough, Rocky Hill, Simsbury, Somers, Suffield, Tolland,. Vernon, and Windsor Locks. (See Map 2.)

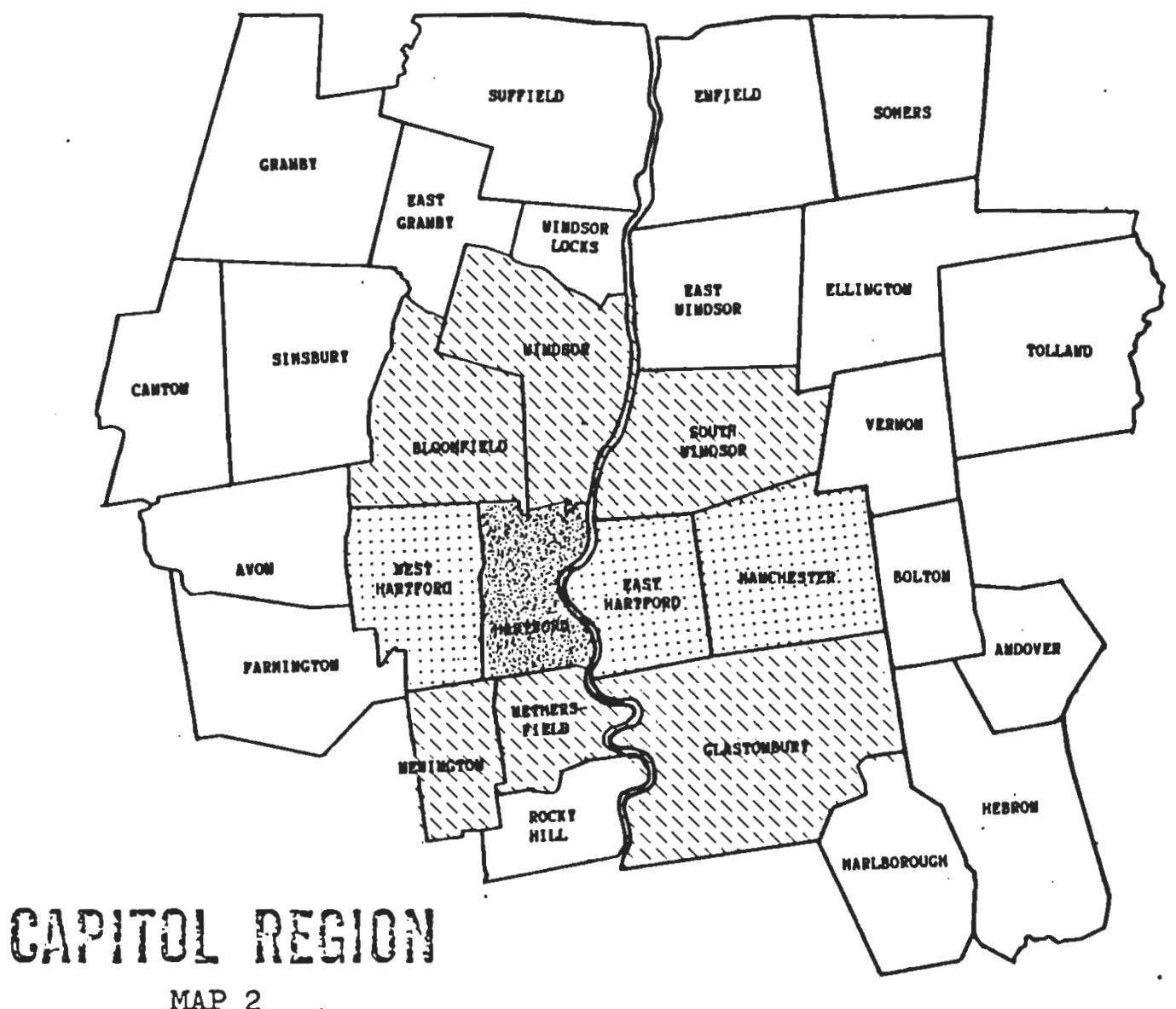


As mentioned previously, the Capitol Region's population is one that is getting older. When each indiuidual city and town within the region is analyzed, one finds that in 1980, 14 communities (almost half) were over the region's median age of 32.0 years. By far the oldest community is the Town of West Hartford, which has a 1980 mediari age of 41.8 years, and was closely followed by the Town of Wethersfield's 1980 median age of 41.4 years. (See Table 17.)

TABLE 17

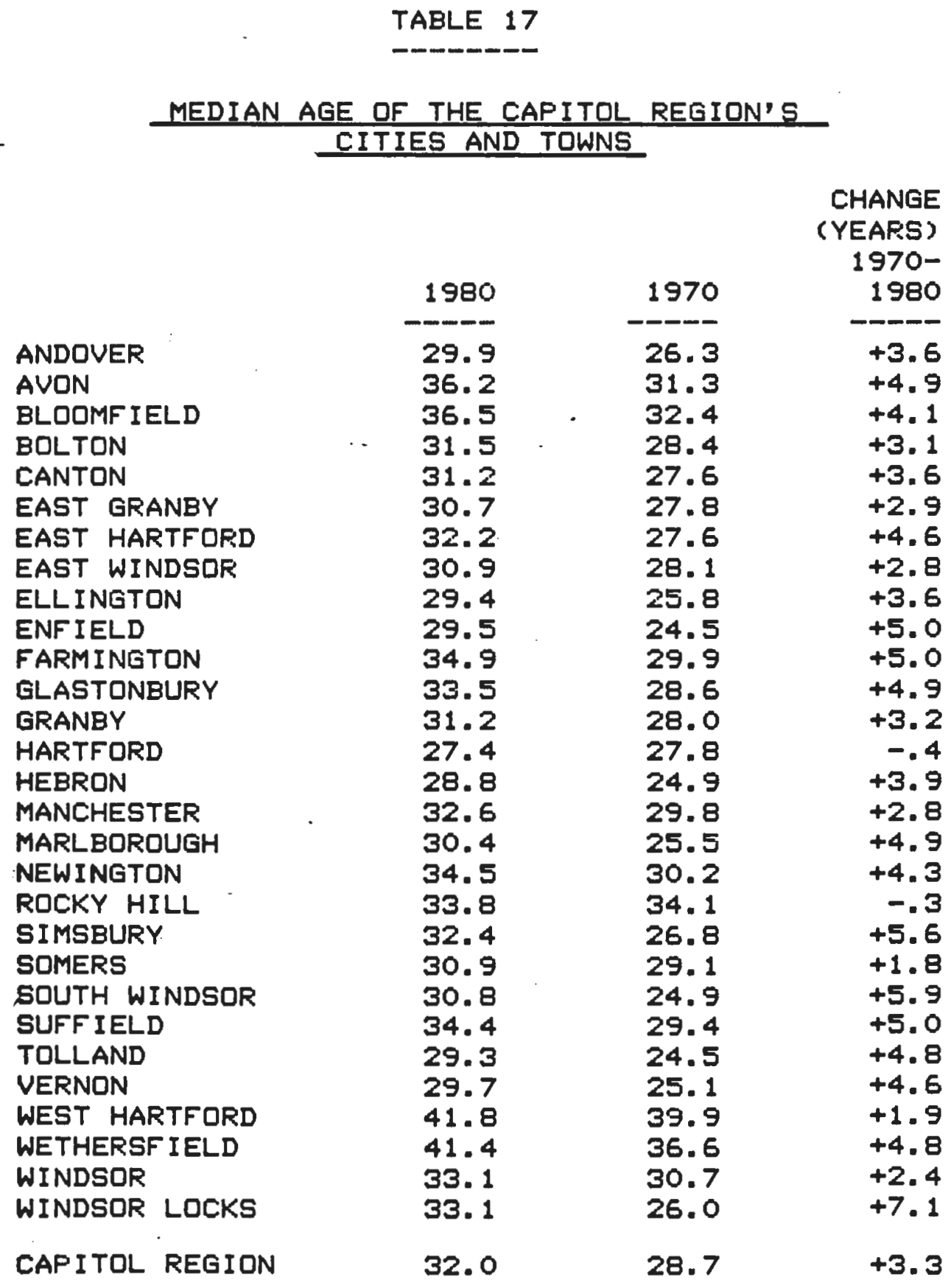

SOURCE:U.5. CENSUS OF CONNECTICUT 1980. 
When the 1980 median age for those comrnunities within the Capitol Region were compared to their 1970 median age, it was found that every city and town except Hartford and Rocky Hill showed an increaso in median age. During this ten-year period, the city of Hartford's median age decreased. 4 years (from 27.8 years in 1970 to 27.4 years in 1980), and the Town of Rocky Hill's median age: decreased. 3 years (from 34.1 years in 1970 to 33.8 years in 1980 ). (See Table 17.)

Although the Towns of West Hartford and Rocky Hill recorded the highest median age within the capitol Region in 1980, their populations' median age did not increase substantially from 1970 , as did some of the other communities' within the region. For example. the Town of West Hartford's median age of its population only rose 1.9 years from 1970 to 1980 (median age was 39.9 years in 1970 and 41.8 years in 1980). The community in the capitol Region with the greatest increase in median age over the 10 year period between 1970 and 1980 was the Town of Windsor Locks. This community's population went from having a median age of 26.0 years in 1970 to 33.1 years in 1980, an increase of 7.1 years. (See Table 17.)

It should be pointed out that only 9 communities within the Capitol. Region experienced a lower median age increase from 1970 to 1980 than the Capitol Region as a whole. They were the Towns of Bolton, East Hartford, East Windsor, Granby, Manchester, Rocky Hill, Somers, West Hartford, Windsor, and the city of Hartford. (See. Table 17 .) 
One reason for the Capitol Region's relatively high median age is due to the substantial number of elderly persons contained within its communities. "As mentioned previously, there were, in 1980 , 77, 018 persons in the Capitol Region 65 years of age or older. These individuals accounted for $11.5 \%$ of the Capitol Region's total pcpuiatior of 668,479 persons.

The breakdown of the Capitol Region's elderly population by individual cities and towns indicates that the City of Hartford and the Town of West Hartford had in 1980, the largest number of elderly persons, i.e., the City of Hartford had 15,499 persons and the Town of West Hartford had 12,391 persons 65 years of age or older. These two communities accounted for $36.2 \%$ of the Capitol Region's entire 1980 elderly population. When the elderly population of the Capitol Region's other two core towns (Manchester and East Hartford) is added to the city of Hartford's and the Town of West Hartford's elderly population, one finds the Capitol Region's center city and . core towns to contain $52.4 \%$ of the Region's 1980 elderly population. (See Map 3 and Table 18.)

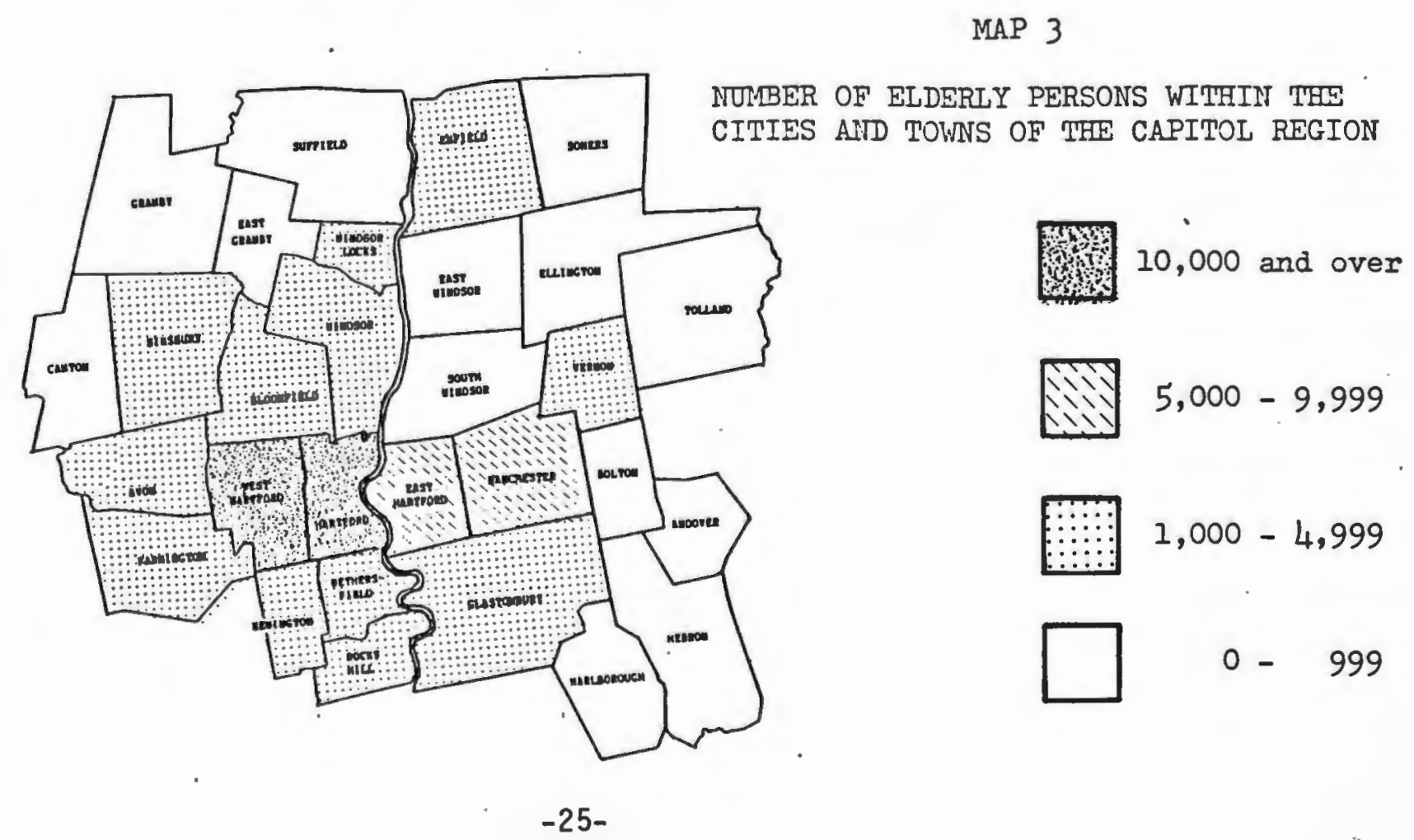


1980 ELDERLY PQPULATION FOR THOSE CITIES AND TOWNS WITHIN THE CAPITOL REGION

\begin{tabular}{|c|c|c|c|}
\hline ANDQVER & 2,144 & 146 & 6.8 \\
\hline AVON & 11,201 & 1,243 & 11.0 \\
\hline BLDOMF IELD & 18,608 & 2,789 & 14.9 \\
\hline BOLTON & 3,951 & 302 & 7.6 \\
\hline CANTON & 7,635 & 705 & 9.2 \\
\hline EAST GRANBY & 4,102 & 284 & 6.9 \\
\hline EAST HARTFORD & 52,563 & 5,927 & 11.2 \\
\hline EAST WINDSOR & 8,925 & 978 & 10.9 \\
\hline ELLINGTON & 9,711 & 672 & 6.9 \\
\hline ENF IELD & 42,695 & 3,235 & 7.5 \\
\hline FARMINGTON & 16,407 & 2,001 & 12.1 \\
\hline GLASTONBURY & 24,327 & 2,221 & 9.1 \\
\hline GRANBY & 7,956 & 517 & 6.4 \\
\hline HARTFDRD & 136,392 & 15,499 & 11.3 \\
\hline HEBRON & 5,453 & 259 & 4.7 \\
\hline MANCHESTER & 49,761 & $6,5 \in 3$ & 13.1 \\
\hline MARLBOROUGH & 4,746 & 25B & 5.4 \\
\hline NEWINGTON & 28,841 & 3,348 & 11.6 \\
\hline ROCKY HILL & 14,559 & 1,948 & 13.3 \\
\hline SIMSBURY & 21,161 & 1,436 & 6.7 \\
\hline SOMERS & 8,473 & 653 & 7.7 \\
\hline SOUTH WINDSOR & 17,198 & 976 & 5.6 \\
\hline SUFF IELD & 9,294 & 960 & 10.3 \\
\hline TOLLAND & 9,694 & 452 & 4.6 \\
\hline VERNON & 27,974 & 2,584 & 9.2 \\
\hline WEST HARTFORD & 61,301 & 12,391 & 20.2 \\
\hline WETHERSF IELD & 26,013 & 4,520 & 17.3 \\
\hline WINDSOR & 12,190 & 1,121 & 9.1 \\
\hline WINDSOR LOCKS & 25,204 & 3,030 & 12.0 \\
\hline CAPITOL REGION & 668,479 & 77,018 & 11.5 \\
\hline
\end{tabular}

SOURCE:U.S. CENSUS OF CONNECTICUT 1980.

When comparing the proportion of elderly persons within each Capitol Region community, one finds the Town of West Hartford in 1980 to have the greatest percentage of its population 65 years of age or older. As shown in Table 18, and Map 4, in 1980, 20.2\% of West Hartford's population was elderly. The Town of West Hartford was closely followed by the Towns of Wethersfield and Bloomfield which showed, respectively, $17.3 \%$ and $14.9 \%$ of their populations as 65 years of age or older. 

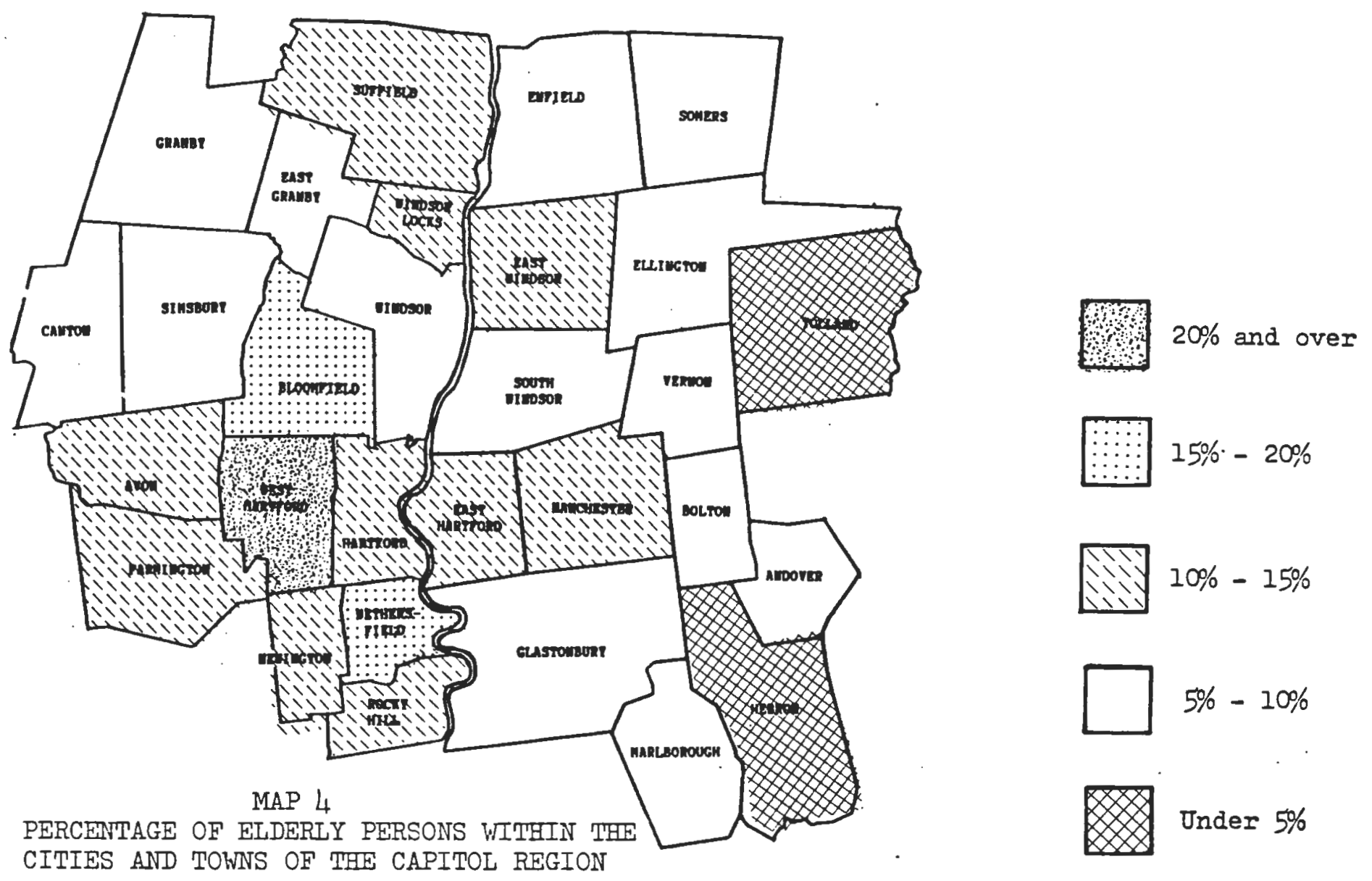

An analysis of the Capitol Region's cities and towns 1980 elderly populations by sex reveals that elderly females outnumbered elderly males in every community. As shown in Table 19, the city of Hartford and the Towns of Enfield, Manchester, Simsbury, Vernon, and West Hartford were at the top end of the spectrum, with $63 \%$ of their elderly populations being female. At the lower end of the spectrum was the Town of Rocky Hill, with its elderly population being almost evenly split between 977 elderly females and 971 elderly males.

It should also be noted that within every Capitol Region community in 1980 , females represented an increasing proportion of the elderly population within each increasing age bracket. For example, the Town of West Hartford had 4,018 fernales to 2,795 males between the ages of 65 and 74 . This gap between elderly females and elderly males increases in the 75 to 84 cohort, wherein there are 
2,885. elderly females to 1,390 males. Finally, the gap is even wider in the 85 years of age and older bracket, where one finds 953 elderly females, as compared to only 34.4 elderly males. (See Table 19.)

TABLE 19

1980 ELDERLY POPULATION BY SEX EOR THOSE CITIES AND TOWNS WITHIN THE CAPITOL REGIION

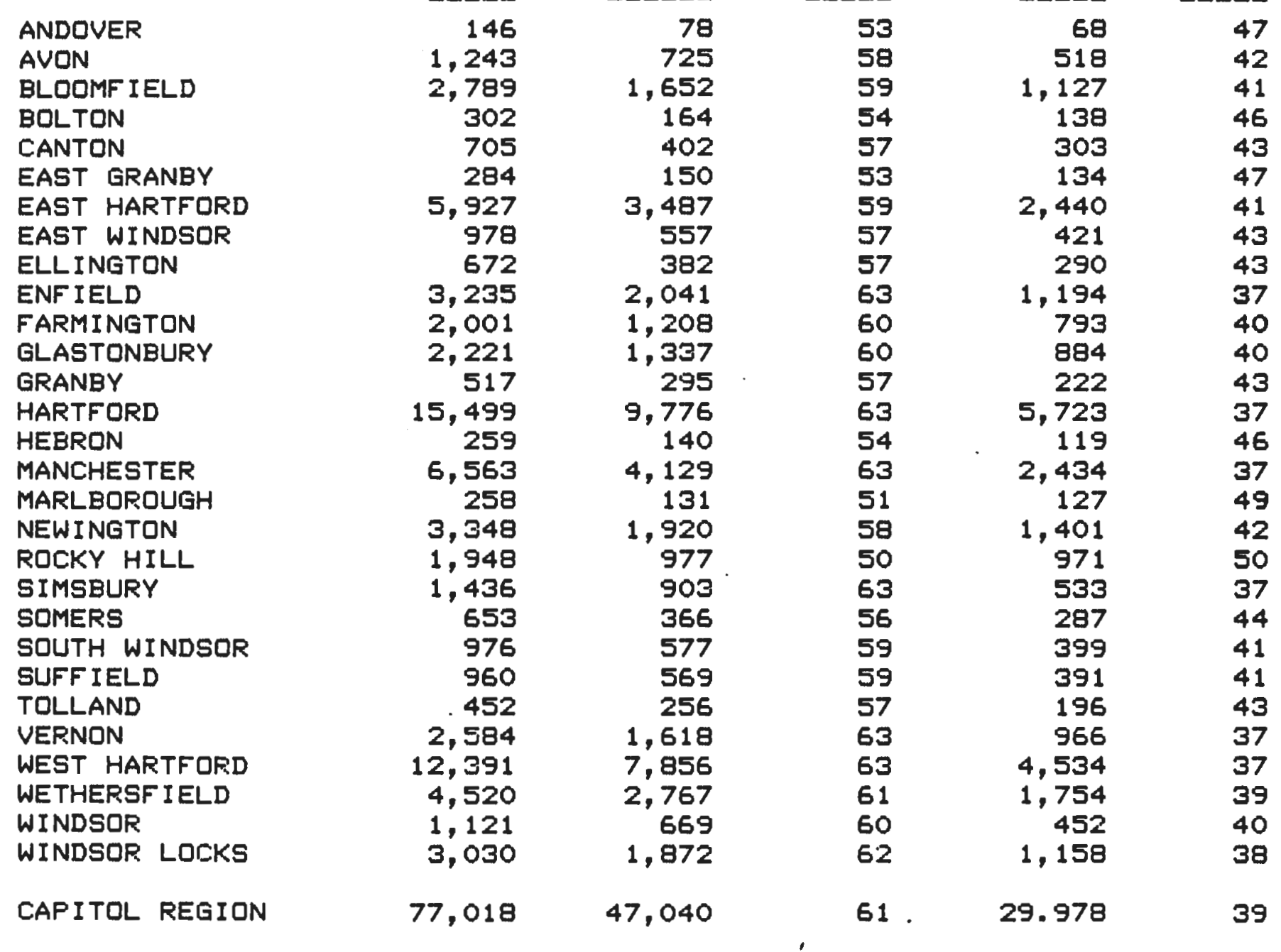

SOURCE:U.S. CENSUS OF CONNECTICUT 1980 .

When the 1980 elderly population within those communities located in the capitol Region is analyzed according to race, one discovers that the majority of the Capitol Region's elderly are 
white. In 1980, 73,156 elderly persons (94.9\% of the capitol

Region's elderly) in the Capitol Region were white, while only 3,862

elderly persons were non-white. By far, the City of Hartford $(12,610$ persons) and the Town of West Hartford $(12,298$ persons) had the largest concentrations of elderly whites. (See Table 20.)

TABLE 20

1980 ELDERLY POPULATION BY RACE FOR THOSE CITIES AND TOWNS WITHIN THE CAPITQL REGION

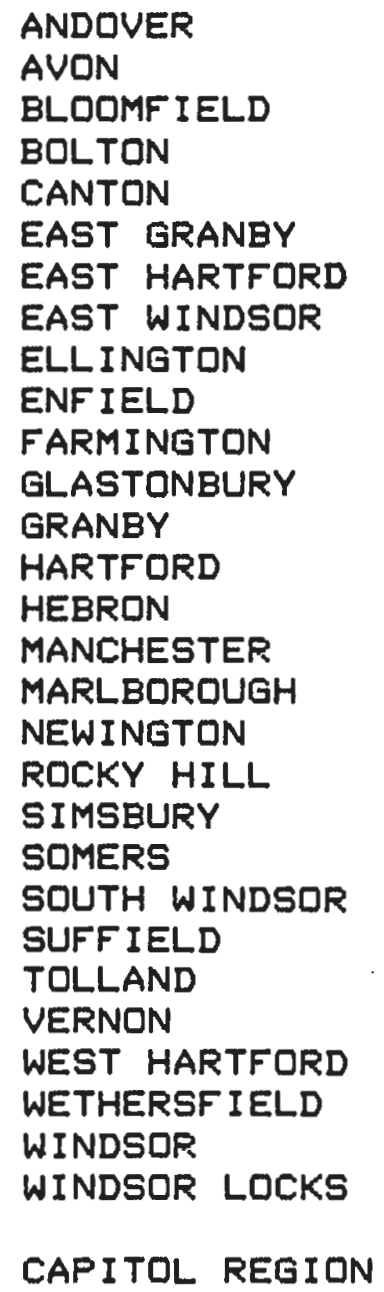

SQURCE:U.S. CENSUS OF CONNECTICUT 1980.

NON-WHITE

\begin{tabular}{|c|c|c|}
\hline $\begin{array}{r}\text { TQTAL } \\
\text { NON-WHITE }\end{array}$ & BLACK & QTHER \\
\hline-- & ---ー- & $----\frac{1}{0}$ \\
\hline $\begin{array}{l}1 \\
6\end{array}$ & $\begin{array}{l}1 \\
6\end{array}$ & $\begin{array}{l}0 \\
0\end{array}$ \\
\hline 342 & 323 & 19 \\
\hline 0 & 0 & 0 \\
\hline 7 & 3 & 4 \\
\hline 5 & 5 & 0 \\
\hline 95 & 58 & 37 \\
\hline 25 & 22 & 3 \\
\hline 4 & 4 & 0 \\
\hline 25 & 13 & 12 \\
\hline 17 & 10 & 7 \\
\hline 18 & 10 & 8 \\
\hline 2 & 2 & 0 \\
\hline 2,889 & 2,423 & 466 \\
\hline 3 & 1 & 2 \\
\hline 39 & 17 & 22 \\
\hline 7 & 4 & 3 \\
\hline 18 & 11 & 7 \\
\hline 24 & 20 & 4 \\
\hline 13 & 4 & 9 \\
\hline 3 & 1 & 2 \\
\hline 25 & 11 & 14 \\
\hline 16 & 16 & 0 \\
\hline 2 & 1 & 1 \\
\hline 22 & 15 & 7 \\
\hline 93 & 43 & 50 \\
\hline 34 & 16 & 18 \\
\hline 115 & 101 & 14 \\
\hline 12 & 6 & 6 \\
\hline 3,862 & 3,147 & 715 \\
\hline
\end{tabular}


As shown in Table 20 , the majority of the Capitol Region's non-white elderly were black and resided in the city of Hartford. In 1980, there were 2,889 non-white elderly persons living in the City of Hartford $(2,423$ elderly black and 466 elderly 'other' Ininoritiez), wilich represented $74.8 \%$ of the Capitol Region's non-white elderly population. This elderly minority population accounted for $18.6 \%$ of Harttord's entire elderly population. The Capitol. Region community with the next largest non-white 342 non-white elderly persons ( $8.8 \%$ of the Capitol Region's non-white elderly population) in 1980.

It is interesting to note that the Town of West Hartford, which in 1980 had the second largest number of elderly persons and the single largest percentage of its population 65 years of age and older, had only 93 elderly non-white individuals. This represented only .75\% of its entire elderly population.

\section{POPULATION PROJECTIONS FOR THOSE PERSONS 65+ FOR EACH CAPITOL REGION}

\section{COMMUNITY}

The Connecticut Department of Health Services, in March 1979 , projected the elderly populations for those communities located within the Capitol Region (see Table 21 and Appendix $C$ for methodology). As euidenced in Table $21^{\prime}$ s elderly population projections, the majority of Capitol Region commuities' elderly populations will peak between 1990 and 1995, then taper off or slightly decline between 1995 and the year 2000.

The majority of the Capitol Region's elderly population growth between 1980 and 2000 is predjcted to occur within the capitol 
Region's outer core, notably the towns of Tolland, Simsbury, and Hebron (see Map 5). The elderly populations of Tolland, Simsbury, and Hebron are projected to increase, respectively, $166.8 \%$ and $127.0 \%, 128.8 \%$ between 1980 and 2000 .

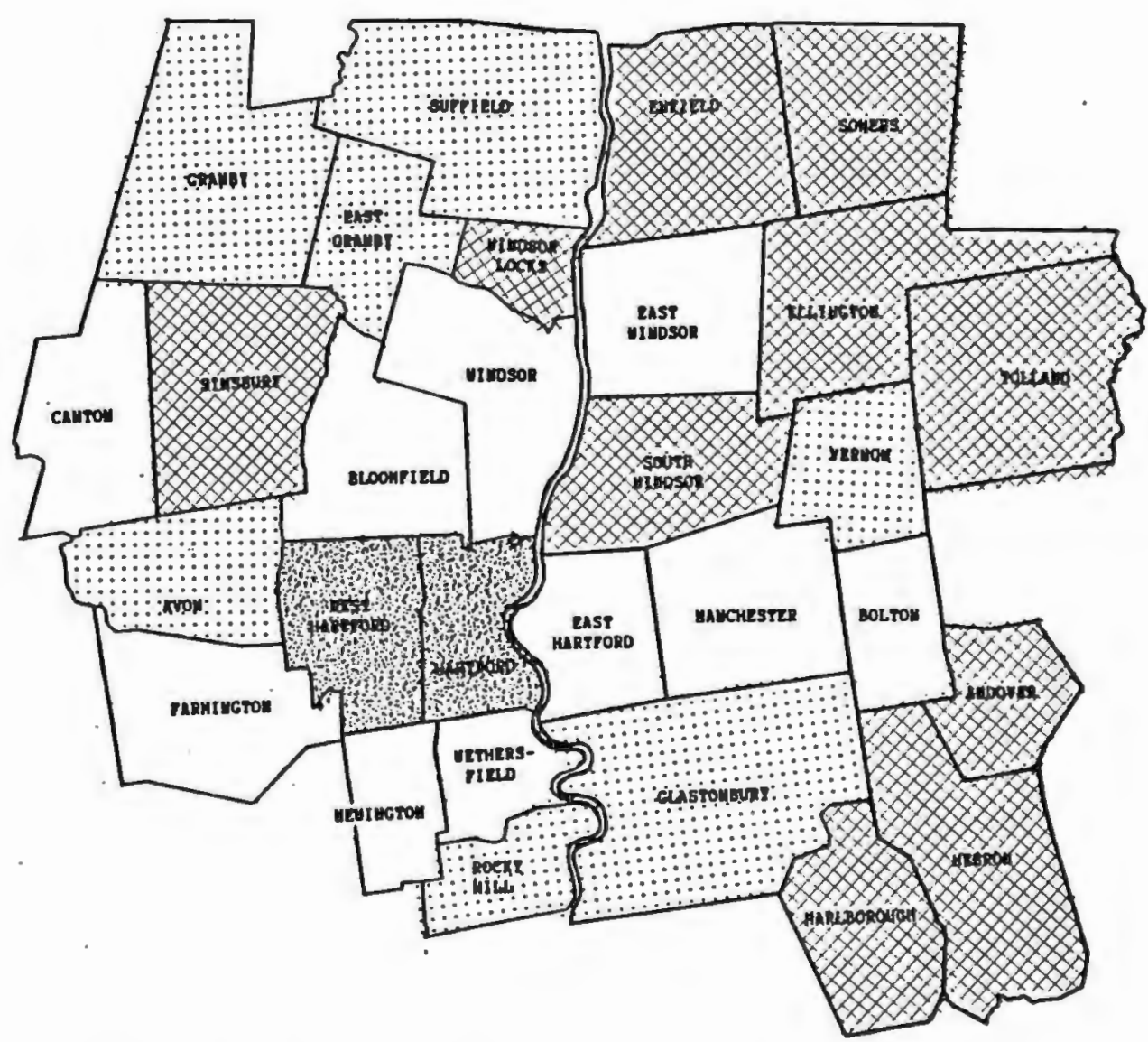

MAP 5

\begin{tabular}{|c|c|}
\hline $\begin{array}{l}\text { IDDERIY POPULAT } \\
\text { (\% change } 1980- \\
\text { THE CITIES AND } \\
\text { CAPITOL REGION }\end{array}$ & $\begin{array}{l}\text { ION GROWTH } \\
\text { 2000) WITHIN } \\
\text { TOWNS OF TWE }\end{array}$ \\
\hline :EGATIVE GROWTH & (under $0.0 \%$ ) \\
\hline LOW GROW'H & $(0.0 \%-33.0 \%)$ \\
\hline MEDIUM GROWTH & $(34.0 \%-67.0 \%)$ \\
\hline HIGH GROWTH & (68.0\% and over) \\
\hline
\end{tabular}


The elderly populations in most of those communities within the Capitol Regjon's inner suburbs, core, and central. city are projected to experience little or no growth in the number of 65 and over indiuiduals from 1980 to the year 2000. (See Map 5 and Table 21.) In fact, the City of Hartford's and the Toun of West Hartford's elderly populations are projected to decline $14.0 \%$ and 10. $7 \%$ respectively, between 1980 and 2000 . The 65 years and ouer populations of these two communities in 1980 accounted for $30.2 \%$ of the Capitol Region's total elderly population. By the year 2,000, this percentage will have declined to $25.7 \%$.

It should be noted that the city of Hartford and the Toun of West Hartford, are the on]y communities within the Capitol Region that are projected to show a negative elderly population growth over the twenty-year period from 1980 to 2000.

In conclusion:

* In 1980, 14. Capitol Region communities (almost half) were over the region's inedian age of 32.0 with the Towns of West Hartford and Wethersfield being the oldest.

* Between 1970 and 1980 every city and town except Hartford and Rocky Hill showed an increase in median age.

* The Capitol Region's relatively high median age in 1980 is due to the substantial number of elderly persons contained within its corninunities.

* In 1980 the majorjty of persons $65+$ are contained within the Capitol Region's center city (Hartford), and core towns (West Hartford, Manchester, and East Hartford) with Hartford and West Hartford having the largest number of elderly indiuiduals.

* of the cities and towns in the Capitol Region in 1980. the Town of West Hartford had the greatest percentage of its population 65 years of age or older. 
TABLE 21

ELOERLY POPLLATION PROJECTIONS FOR EACH CAPITOL REGION CITY AND TOWN (1985-2000)

SOURCE: CONMECTICUT DEPARTMENT OF HEALTH SERUICES, MARCH 1979, HET $1528 \mathrm{C}$. THE PROJECTIONS SHOHN IN THIS TABLE HERE ADJUSTED ACCORDING TO ACTUAL 1980 CENSUS COUNTS (SEE APPENDIX C FOR METHODOLOGY).

PROJECTIONS

\begin{tabular}{|c|c|c|c|c|c|c|c|}
\hline 1985 & 1990 & $\begin{array}{l}2 \mathrm{CH} . \\
1985- \\
1990\end{array}$ & 1995 & $\begin{array}{l}8 \mathrm{CH} . \\
1990- \\
1995\end{array}$ & 2000 & $\begin{array}{l}1 \mathrm{CH} . \\
1995- \\
2000\end{array}$ & $\begin{array}{r}2 \mathrm{CH} . \\
1980 \\
2000\end{array}$ \\
\hline & & --0 & & $\infty-\infty$ & & & "-- \\
\hline 162 & 224 & $(38.2)$ & 241 & $(7.5)$ & 259 & $(7.4)$ & (77.3) \\
\hline 1,499 & 1,584 & $(5.6)$ & 1,954 & $(23,3)$ & 2,081 & $(6,4)$ & $(67.4)$ \\
\hline 3,057 & 3,321 & $(8.6)$ & 3,466 & $(4,3)$ & 3,462 & $(-0.1)$ & $(24.1)$ \\
\hline 323 & 355 & $(9.9)$ & 396 & $(11.5)$ & 392 & $(-1.0)$ & $(29.8)$ \\
\hline 785 & 846 & $(7.7)$ & 894 & $(5.6)$ & 944 & (5.5) & $(33.9)$ \\
\hline 328 & 362 & $(10.3)$ & 406 & $(12.1)$ & 465 & $(14,5)$ & $(63.7)$ \\
\hline 6,245 & 7,364 & $(17.6)$ & 8,034 & $(9.3)$ & 7,841 & $(-2,4)$ & $(32.2)$ \\
\hline 1,134 & 1,259 & $(11.0)$ & 1,308 & $(3.8)$ & 1,274 & $(-2.5)$ & $(30.2)$ \\
\hline 839 & 937 & $(11.6)$ & 1,067 & $(13.8)$ & 1,158 & (8.5) & $(72.3)$ \\
\hline 3,926 & 4,858 & $(23.7)$ & 5,813 & $(19.6)$ & 6,725 & $(15.6)$ & $(107.8)$ \\
\hline 2,308 & 2,510 & $(8.7)$ & 2,646 & $(5.4)$ & 2,644 & $(0.0)$ & $(32.1)$ \\
\hline 2,671 & 3,132 & $(17.2)$ & 3,405 & $(8.7)$ & 3,606 & $(5.9)$ & $(62.3)$ \\
\hline 625 & 733 & $(17,2)$ & 804 & $(9,6)$ & 845 & $(5.0)$ & $(63.4)$ \\
\hline 15,720 & 15,544 & $(-1,1)$ & 15,054 & $(-3,1)$ & 13,325 & $(-11,4)$ & $(-14,0)$ \\
\hline 329 & 381 & $(15.8)$ & 461 & $(20.9)$ & 588 & $(27.5)$ & $(127,0)$ \\
\hline 7,371 & 7,640 & $(3,6)$ & 7,349 & $(-3.8)$ & 6,835 & $(-6,9)$ & (4.1) \\
\hline 300 & 344 & $(14,6)$ & 389 & $(13.0)$ & 438 & $(12.5)$ & (69.7) \\
\hline 3,968 & 4.411 & $(11,1)$ & 4.505 & $(2,1)$ & 4,394 & $(-2,4)$ & $(31,2)$ \\
\hline 2,260 & 2,456 & $(8.6)$ & 2,560 & $(4.2)$ & 2,725 & $(6,4)$ & $(39.8)$ \\
\hline 2,051 & 2,598 & $(26.6)$ & 3,155 & $(21.4)$ & 3,286 & $(4,1)$ & $(128.8)$ \\
\hline 842 & 1.018 & $(20.9)$ & 1,203 & $(18,1)$ & 1,341 & $(11,4)$ & $(105.3)$ \\
\hline 644 & 990 & $(53.7)$ & 1,429 & $(44.3)$ & 1,889 & $(32.1)$ & $(93.5)$ \\
\hline 1,176 & 1,346 & $(14,0)$ & 1,461 & $(8.5)$ & 1,549 & $(6,0)$ & (61.3) \\
\hline 591 & 792 & $(34,0)$ & 1.000 & $(26,2)$ & 1,206 & $(20,6)$ & $(166,8)$ \\
\hline 2,815 & 3,076 & (9.2) & 3,293 & $(7.0)$ & 3,489 & (5.9) & $(35.0)$ \\
\hline 12,408 & 12,433 & $(0.2)$ & 12,104 & $(-2.6)$ & 11,062 & $(-8,6)$ & $(-10.7)$ \\
\hline 5,581 & 5,083 & $(-8,9)$ & 5,179 & $(1.8)$ & 5,104 & $(-1,4)$ & $(12.9)$ \\
\hline 3,320 & 3,667 & $(10.4)$ & 3,775 & $(2,9)$ & 3,717 & $(-1.5)$ & $(22,6)$ \\
\hline 1,313 & 1,724 & $(31.3)$ & 2,007 & $(16.4)$ & 2,089 & $(4.0)$ & $(86,3)$ \\
\hline 84,591 & 90,670 & $(7.1)$ & 95,358 & $(4.8)$ & 94,733 & $(-0.6)$ & $(23.0)$ \\
\hline
\end{tabular}


* In 1980 elderly females outnumbered elderly males in every one of the Capitol Region's cities and towns.

* Analysis of each Capitol. Region community showed the proportion of elderly females to elderly males to grow with each increasing age bracket (with females outnumbering males substantially).

* In 1980 the majority of the Capitol Region's elderly were white.

of the 29 cities and towns in the Capitol Region in 1980 , the rnajority of non-white elderly individuals resided in the City of Hartford.

* The elderly population growth within the majority of Capitol. Region Communities will peak between 1990 and 1995, then taper off or slightly decline between 1995 and the year 2000 .

* The majority of the elderly population growth between 1980 and 2000 is predicted to occur within the capitol Region's outer core towns.

* The Capitol Region's inner suburbs, core and central city are projected to experience little or no growth in their elderly populations between 1980 and the year 2000 . 


\section{CHAPTER TWO}


In 1985, elderly residents within the Capitol Region that meet certain eligibility requirements can fulfill their housing needs either through one of the Region's low and moderate income housing developments, ur ihrough the Federal Governinents Section 8 Rrmt.z? Assistance program, which allows applicants to rent in the private housing market. This chapter will discuss the availability of both programs to the elderly of the Capitol Region.

\section{GOUERNMENT ASSISTED LOW AND MODERATE INCOME HOUSING DEUELOPMENTS}

In 1985, there are 150 low and moderate income housing developments (total includes 11 new complexes which have recently been completed or are in the process of being completed) distributed throughout 27 of the Capitol Region's 29 cities and towns. (See Map 6.) These housing developments are either exclusively elderly or contain a combination of elderly/family units.

Analysis of the composition, eligibility, cost and distribution of elderly units within the Capitol Region's low and moderate income housing developments shows the following: (see Table 22.)

\section{COMPOSITION}

* The Capitol Region contains 14,052 elderly and family units, of which 8,541 wnits are exclusively elderly (includes 398 designated handicapped units). It should be noted that in this elderly unit total, it is assumed that elderly tennants only occupy "efficiency and one bedroom units" in combined elderly/family low and moderate income housing complexes. 
THE LAFITCL FEEION LITIES AND TCWNS

WITH GOVEFNMENT ASSISTED LCW AND MOEEEATE

INLOME HOUSING DEVELCFMENTS FLE THE ELDEFLY

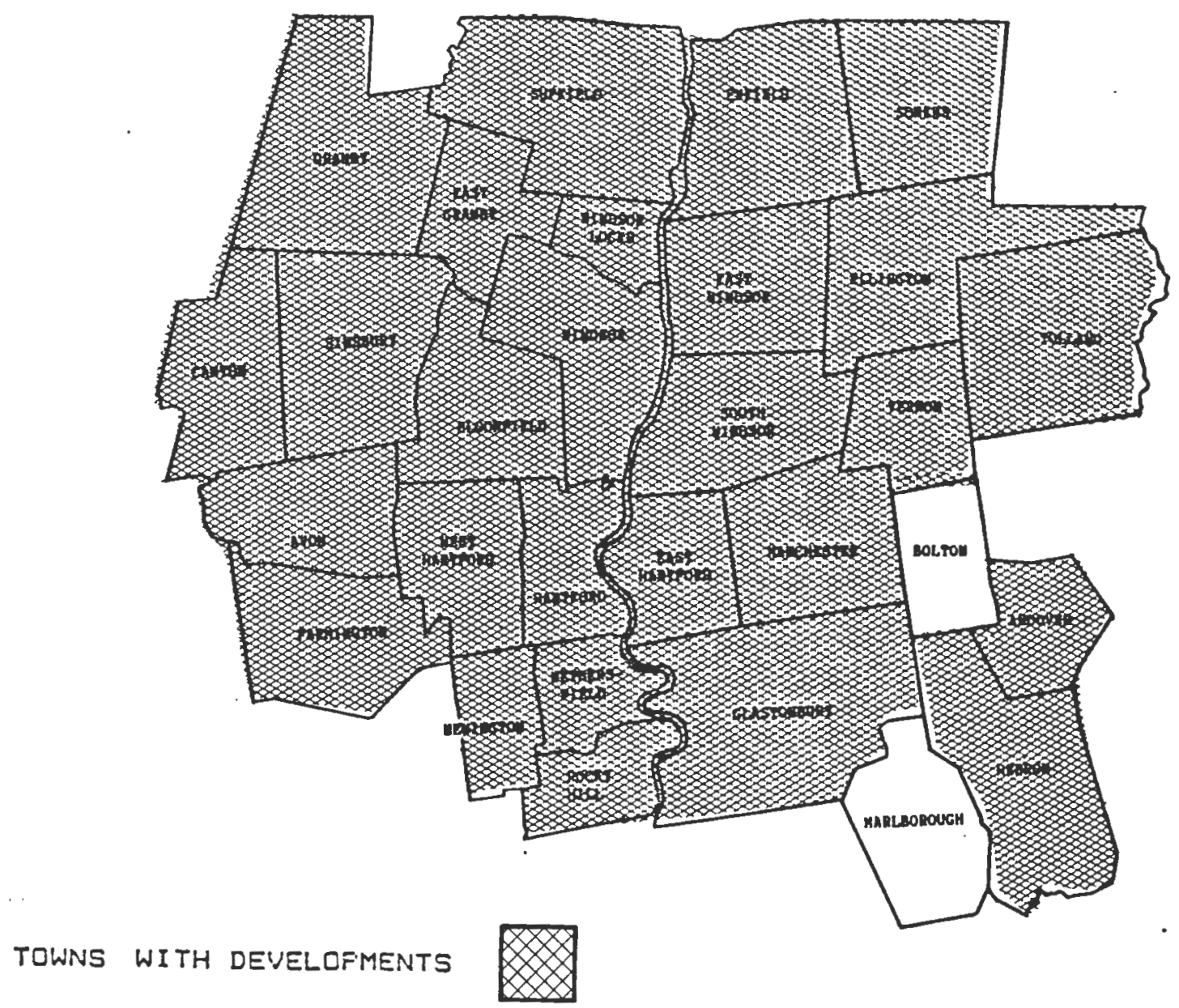

* The majority. of the Capitol Region's elderly units 6,091 are one bedroom units, foll. owed by 2,131 efficiencies, 264 two bedroom units, 41 three bedroom units, and 14 four bedroom units.

\section{ELIGIBIIITY}

* The maximum income level allowed for these units varjes between complexes and towns, but in most cases, it ranges between $\$ 11,750$ and $\$ 21,450$, depending on the 
Maret

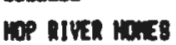

TOTML

Nhin

nom ELo.

TOTK

MOBFIEI

\section{C.Mrnoman nille}

moosice viluase

IMTERA AITH BDTE

IMIEXSAITH VILUE

Qocisitel ceatreres

FEMERITIO Mored

TOTM

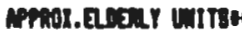

canton

minc aen

21 oow

TOTM

EAst and

intuconet hines

hratty viLuas

PoTA

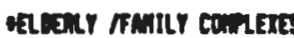

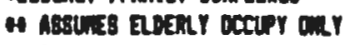

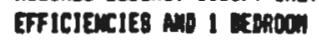

- unirs in caberlifanily

couplexes.
2350

$10750-21450$

$21450-33500$

$18750-21450$

$18750-21450$

$18750-21450$

$13400-22100$

$11750-13400$

\begin{tabular}{|c|c|c|c|}
\hline 302 & YES & YEB & YEs \\
\hline 302 & res & TES & Ye8 \\
\hline 302 & YES & YEE & rEs \\
\hline 302 & res & res & 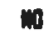 \\
\hline 302 & YEB & YES & YES \\
\hline 302 & YES & YEs & res \\
\hline
\end{tabular}

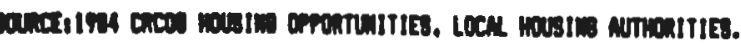

MAMICAPPE (UNITS INC. IN ELERLY TOTALI

UnIT

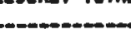

3 
EAST MAMTFORO

acen garodis

NOCHMEEN APTS.

TEOBW HILL

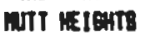

Gins VILLAE

MERITAGE GARDEISS

HIELARDS

MILLER GROCE

MLEY COLAT

HARTFURO ERST IPTS.

E. HARTTOEO ESTATES

ST. BhaY's apts.

viluow mans

BT. ELIZABETH APTB. INET)

IOTM

\begin{tabular}{|c|c|c|c|c|c|c|c|c|c|c|c|c|}
\hline maniminim & $\begin{array}{c}\text { REDI } \\
\text { RANEES }\end{array}$ & KEN & Midter & ELEC. & EFF. & $18 R$ & 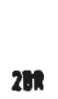 & 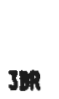 & 4BR & 568 & $\begin{array}{r}\text { TOTAL } \\
\text { EDERRLY } \\
\text { UNITS }\end{array}$ & $\begin{array}{l}\text { MAMDICAPPEN } \\
\text { IUNITS IIC. IN } \\
\text { ELEERLY TOTALI }\end{array}$ \\
\hline & $+\infty$ & & $\cdots$ & 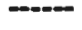 & $-\infty$ & $\cdots$ & $\cdots$ & $\cdots$ & $\cdots$ & $\cdots$ & - & 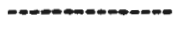 \\
\hline
\end{tabular}

mpror. agetar ontren

13700-24500

$13700-15600$
15600

\begin{tabular}{|c|c|c|c|}
\hline 302 & rE: & VEB & VES \\
\hline 302 & VEB & YEB & res \\
\hline 302 & rES & TES & YES \\
\hline 302 & rE: & YES & YES \\
\hline 251 & VEB & res & rES \\
\hline 301 & res & YES & YES \\
\hline 302 & VES & rES & res \\
\hline 302 & Yes & res & VES \\
\hline 302 & VEB & VEB & YEB \\
\hline 252 & YES & rEB & YES \\
\hline 302 & VEB & rEs & . YEB \\
\hline 302 & res & rEs & YES \\
\hline 302 & YES & VES & VES \\
\hline 302 & YES & VES & VES \\
\hline 302 & rES & rES & res \\
\hline
\end{tabular}

$15200-17400$

$13700-15600$

13700
$13700-15800$

13700

15250-17100

$11750-13400$

$21450-26800$

$18750-21450$

$18750-21450$

$11750-13400$

EAst uIneso

pmx mIL

gPrIms viLLAe

9. CIIILE ATS. (IEI)

TOTA

23500

$13000-14800$

$\begin{array}{ll}\mathbf{2 5 1} & \text { TES } \\ 251 & \text { VES } \\ 251 & \text { YrS }\end{array}$

$3000-18000$
23500
23500

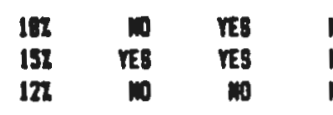

Torm

enterie vius:

IIC TOC TOwintose

menot acaly mites

Allour Fanty combat

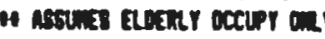

entcieicies an I Earoo

outrs in eloencrifanilly

chirlexes.

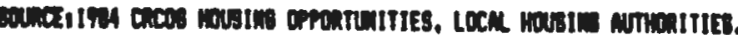




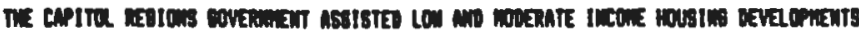

\begin{tabular}{|c|c|c|c|c|c|c|c|c|c|c|c|c|c|}
\hline & $\begin{array}{c}\text { mutimn } \\
\text { Incone (8) }\end{array}$ & $\begin{array}{l}\text { nem } \\
\text { nanges }\end{array}$ & . MEMT & MTI & ELEC. & EFF. & 10 & 2 & 36 & 48R & SER & $\begin{array}{l}\text { TOTM } \\
\text { ELUERLY } \\
\text { UNITS }\end{array}$ & $\begin{array}{l}\text { HARPICAPPED } \\
\text { IUAIS ILC. IN } \\
\text { EL JERLY TUTML) }\end{array}$ \\
\hline E. TheII & & & & & & & & & & & & & \\
\hline 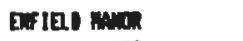 & $13000-14000$ & $\mathbf{2 s}$ & ras & VE & rEs & $\omega$ & 20 & -- & - & -- & - & $\infty$ & \\
\hline UIWUSOR COLRT & $13000-14600$ & 252 & $\mathbf{m}$ & $\omega$ & $\boldsymbol{m}$ & $\infty$ & 20 & -- & - & - & $\ldots$ & 10 & \\
\hline WOOSIUE PAAK & $13000-14000$ & $25 \mathbf{t}$ & $\mathbf{m}$ & m & m & - & 10 & - & - & -- & -- & 40 & \\
\hline GL ERAsso mand & $13000-14800$ & 252 & $\mathbf{m}$ & 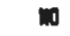 & $\mathbf{m}$ & - & 42 & -- & - & -- & - & 42 & \\
\hline MaRK RMIM EAICFEO & $13000-14800$ & 25t & re & VES & res & - & 10 & - & - & -- & - & 40 & \\
\hline FRESHWATER POHAS & $18750-33500$ & 302 & rE6 & YES & $\mathbf{m}$ & - & 15 & 17 & 30 & is & $\cdots$ & 75 & 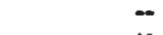 \\
\hline Torm & & & & & & 120 & 17 & 17 & 30 & is & - & 39 & 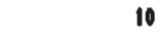 \\
\hline 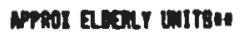 & & & & & & 120 & in & -- & - & - & -- & 297 & $\boldsymbol{I}$ \\
\hline
\end{tabular}

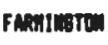 \\ mare viune \\ Fanenimsion Keierts \\ THIIIS IPTS: \\ FOAEST COMT! \\ ESTEMLE IOH \\ TOTA}

mpror abear mitse

anstowion

\section{and viure}

VIU MES ERED

mor lane

STILL HIL

VELES VIUNGE:

Toik

$13000-14000$
$22300-31650$
$22300-35950$
$18790-21450$
$11750-13400$

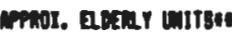

and

BTOET MIL

TDIM

2550

$13000-14000$

$13000-14000$

13400-11000

$11750-22100$

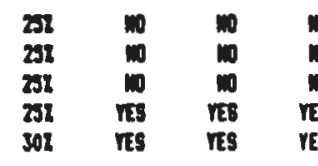

$\begin{array}{ll}12 & - \\ 1 & 40 \\ 12 & 16 \\ 11 & 18 \\ 30 & - \\ 16 & 14 \\ 76 & \end{array}$

$\begin{array}{cccc}- & - & - & 40 \\ - & - & - & 14 \\ - & - & 32 \\ - & - & 36 \\ - & - & 10 \\ 1 & - & 112\end{array}$

$-$

Heger frmily comern

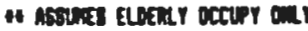

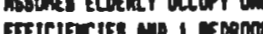

cricigares

cirs in we

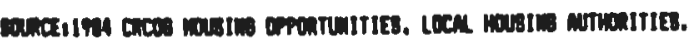




\begin{tabular}{|c|c|c|c|c|c|c|c|c|c|c|c|c|c|}
\hline \multirow[b]{2}{*}{ MRTro: } & $\underset{\text { Jucaue (I) }}{\operatorname{minum}}$ & $\begin{array}{c}\text { MET. } \\
\text { RAMEES }\end{array}$ & & EFF. & Im & $200 \mathrm{n}$ & $\operatorname{sen}$ & 4h & \multicolumn{2}{|c|}{$\begin{array}{l}\text { TOTM } \\
\text { ECOERLY }\end{array}$} & $\begin{array}{l}\text { MANDICAPPED } \\
\text { lUNITS IIC. IR } \\
\text { GDERLY TOTALI }\end{array}$ \\
\hline & & & & & & & & & & & & & \\
\hline maner villase & $11750-13400$ & 302 & na & VEB & $\mathbf{m}$ & . & $\boldsymbol{s}$ & - & $-\infty$ & -. & - & 50 & - \\
\hline reLEVL SRUARE! & $11750-22100$ & 302 & Yes & res & VEB & -- & $\mathbf{x}$ & m4 & 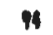 & 99 & 4 & 309 & - \\
\hline IELSOM cownI! & $11730-22100$ & 302 & res & res & VES & - & 36 & 76 & 30 & 6 & -- & 156 & -. \\
\hline KENT MPTS. & $11730-13400$ & 308 & VES & VES & res & $t$ & 30 & .- & - & $\ldots$ & -- & 39 & - \\
\hline reRcivK surth foukns & $11730-13400$ & 302 & VES & VES & YES & - & 200 & - & - & -- & -. & 200 & - \\
\hline CIARTER ouK TERRACE & $11730-22100$ & 302 & YES & VES & YES & - & 124 & 411 & 292 & $\cdot 106$ & 13 & 946 & 12 \\
\hline STOM VIUAee, & $11750-22100$ & 302 & YES & YES & YES & -- & 60 & 306 & 182 & 30 & 12 & 398 & 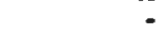 \\
\hline RLE KEIETIS & $18750-353900$ & 302 & YEB & res & $m$ & - & 44 & 236 & $\omega$ & 46 & 2 & 360 & 10 \\
\hline NUTCH POIMT: & $11730-22100$ & 302 & VES & res & YEB & - & 52 & $\%$ & 38 & 14 & - & $\mathbf{m 2}$ & - \\
\hline coucs pate & $16640-20640$ & 232 & VEB & TES & $m$ & - & 116 & 236 & 30 & $\therefore$ & -- & 110 & - \\
\hline EIIY now APTB. & $11730-13400$ & 302 & YEB & res & reB & IJI & 67 & 1 & - & . & $\ldots$ & 199 & - \\
\hline QAN HILL & $11750-22100$ & 302 & rEs & res & res & - & 10 & 38 & 60 & 21 & 7 & 156 & 17 \\
\hline 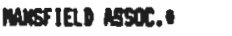 & $18730-35500$ & 302 & reQ & res & rES & - & 25 & 33 & 2 & -- & - & 10 & - \\
\hline 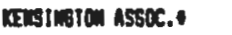 & $10750-21450$ & 302 & res & MES & res & - & 31 & 5 & - & -. & $\cdots$ & 36 & - \\
\hline UPPER Baroests MSSCC." & $10750-21450$ & 302 & VEB & res & res & -- & 16 & 4 & 30 & 4 & 1 & $\varphi$ & - \\
\hline In.50m ns50C.1 & $18750-50150$ & 302 & YES & res & VES & - & , & 36 & 12 & - & - & 55 & - \\
\hline PAVIULJOW 1550C.: & $18750-353500$ & 302 & res & res & MEB & -- & jo & j3 & 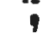 & -- & - & $n$ & - \\
\hline m. RIVE MUESP & $10730-30130$ & 301 & YEB & res & VEB & - & 4 & 39 & 1 & - & - & 11 & - \\
\hline canitr ticks & $11750-13400$ & 302 & VES & TEB & VEB & .. & 136 & : & - & - & - & 141 & - \\
\hline 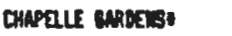 & $13400-22100$ & 302 & VES & res & $m$ & - & 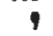 & 27 & 3 & III & - & ite & - \\
\hline TEM Musthul Mouse & $11750-21400$ & 302 & res & res & YES & 32 & 13 & $\cdots$ & - & - & - & 115 & - \\
\hline 81. Danistone MPTS. & $18750-21450$ & 302 & $\mathrm{mi}$ & res & res & 20 & $n$ & 1 & - & -- & - & 100 & - \\
\hline nala rexona & $11730-13400$ & 302 & YES & VEB & YeE & -. & - & - & 4 & 10 & - & 14 & - \\
\hline MRI EAROETSI & $22300-35050$ & 302 & YEB & res & $m$ & - & $\bullet$ & 3 & 10 & - & - & 34 & $\therefore$ \\
\hline $\operatorname{san} 0+2$ & $11730-22100$ & 302 & ras & VEs & VEB & 16 & 119 & 75 & 3 & I & - & 272 & -- \\
\hline SEPARO PAX . & $18750-21450$ & 302 & YEA & res & YES & 17 & 290 & 66 & - & 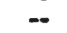 & - & 373 & $\mathbf{s}$ \\
\hline CASA nEVA MTR. & $11750-22100$ & 302 & YEB & res & $m$ & -- & 11 & 26 & $n$ & II & 2 & $n$ & 2 \\
\hline 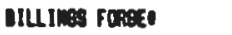 & $11730-19430$ & 302 & YEB & res & res & -- & 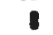 & , & 3 & - & - & 20 & 2 \\
\hline Tomouse wTe." & $22300-31630$ & 302 & res & VEB & res & 6 & 21 & i & - & -. & - & 36 & - \\
\hline 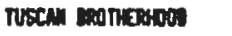 & $10750-26800$ & 302 & nes & res & YES & -. & 108 & 12 & - & - & - & 120 & - \\
\hline Ireouner saune & $10750-21450$ & 302 & YEB & VES & VES & -- & 12 & -- & -- &.- & - & 12 & 4 \\
\hline EROTKEAHOOS ROTES & $11730-13400$ & 302 & VEs & TEB & VES & 44 & 6 & - & - & -- & - & 50 & - \\
\hline Jncxsou cemten: & 1E750-35500 & 302 & YES & res & res & -- & 12 & $n$ & 15 & 6 & 1 & 36 & .. \\
\hline ASRU reste & $18750-13400$ & 302 & NES & res & $\boldsymbol{m}$ & $\mathbf{3}$ & 12 & 15 & - & -- & -. & 30 & $\mathbf{J}$ \\
\hline Mark rejarts & Lo LInIIS & $1257-397$ & YES & res & YES & $\mathbf{2 6}$ & 32 & 10 & - & -- & $\ldots$ & 60 & -- \\
\hline VILE cant & w LInIts & $1233-265$ & YEB & YES & res & 12 & 1 & -- & - & -- & - & 20 & .- \\
\hline tmatag have & $11750-21450$ & 302 & res & VEB & res & 146 & 50 & .- & - & - & - & 204 & - \\
\hline En s1.mosoc.p & $11750-19430$ & 302 & rES & VE\& & VEB & - & 24 & 12 & 13 & - & -. & 11 & - \\
\hline LOEER Gaded A5SOC.1 & $18750-30150$ & 301 & ret & res & YES & 6 & 6 & 39 & - & - & - & 31 & - \\
\hline
\end{tabular}

cterar fratir comates

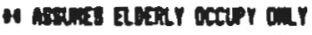

EFICIETCIES AD I KBAO

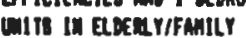

concteres.

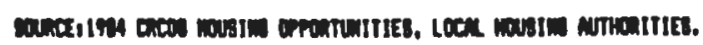




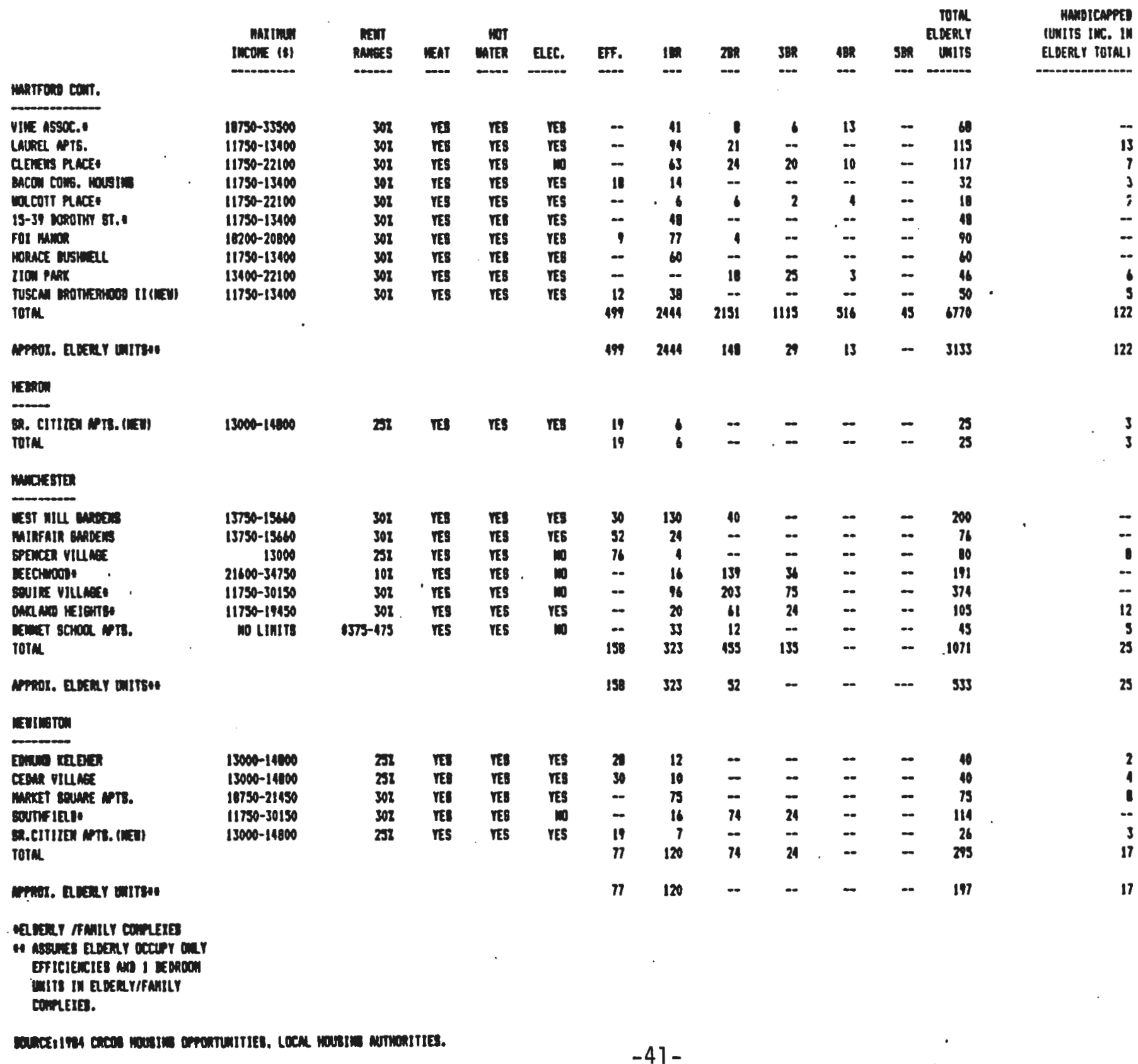




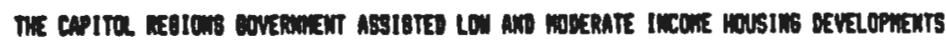

\begin{tabular}{|c|c|c|c|c|c|c|c|c|c|c|c|c|c|}
\hline & $\begin{array}{r}\text { marimin } \\
\text { Imcone (i) }\end{array}$ & $\begin{array}{l}\text { REIT } \\
\text { RAMEES }\end{array}$ & MEAT & $\begin{array}{r}\text { MOT } \\
\text { MATER }\end{array}$ & EEC. & EFF. & 18R & 208 & 3 & 408 & 589 & $\begin{array}{l}\text { TOTML } \\
\text { RDERLY } \\
\text { UNITS }\end{array}$ & $\begin{array}{l}\text { HAMDICAPPED } \\
\text { (UNITS INC. II } \\
\text { ELDERLY TOTALI }\end{array}$ \\
\hline \multicolumn{14}{|l|}{ rockY HIL } \\
\hline $\begin{array}{l}\text { Docer HIL SETIOR } \\
\text { Total }\end{array}$ & $13000-14800$ & 252 & rES & res & $\mathbf{m}$ & $\begin{array}{l}30 \\
30\end{array}$ & $\begin{array}{l}10 \\
10\end{array}$ & - & $\ddot{-}$ & $-\overline{-}$ & - & $\begin{array}{l}40 \\
40\end{array}$ & 4 \\
\hline \multicolumn{14}{|l|}{ sinswem } \\
\hline 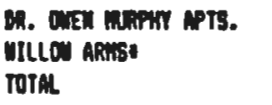 & $\begin{array}{l}13000-14800 \\
11750-16750\end{array}$ & $\begin{array}{l}252 \\
302\end{array}$ & $\begin{array}{l}\text { res } \\
\text { res }\end{array}$ & $\begin{array}{l}\text { res } \\
\text { rEs }\end{array}$ & $\underset{m}{m}$ & $\frac{19}{49}$ & $\begin{array}{l}21 \\
29 \\
49\end{array}$ & $\begin{array}{l}m \\
53\end{array}$ & $\ddot{-}$ & $\begin{array}{l}-- \\
--\end{array}$ & $\ddot{-}$ & $\begin{array}{r}70 \\
81 \\
151\end{array}$ & $\overline{-}$ \\
\hline 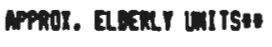 & & & & & & 49 & 49 & - & - & - & - & 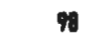 & - \\
\hline \multicolumn{14}{|l|}{ SOLIERS } \\
\hline $\begin{array}{l}\text { LOODCAEST } \\
\text { TOTML }\end{array}$ & $13000-14800$ & 252 & res & YES & YES & 39 & $\begin{array}{l}15 \\
15\end{array}$ & -- & $\overline{-}$ & $\overline{-}$ & - & $\begin{array}{l}34 \\
54\end{array}$ & $\overline{-}$ \\
\hline \multicolumn{14}{|l|}{ soum mostin } \\
\hline $\begin{array}{l}\text { MAPPIUB KET } \\
\text { TOTML }\end{array}$ & $13000-14800$ & 251 & $m$ & rES & res & $\begin{array}{l}\mathbf{2 n} \\
\mathbf{2 2}\end{array}$ & : & $\overline{-}$ & - & -- & $\overline{-}$ & $\begin{array}{l}30 \\
30\end{array}$ & $\overline{-}$ \\
\hline APLE COUnt & $13000-14800$ & 252 & $\mathbf{m}$ & $\mathbf{m}$ & $m$ & 14 & 6 & -- & - & - & - & 20 & - \\
\hline LARE coth! & $13000-14800$ & 252 & $\omega$ & no & $\mathbf{m}$ & 20 & 10 & -- & - & - & - & 30 & - \\
\hline PMA PLACE , & 23500 & 252 & YES & YES & $m$ & -- & 40 & - & - & -. & - & 10 & 4 \\
\hline SR. CITILEW IPTB. (IIIN) & $13000-14900$ & $25 \%$ & 10 & No & 10 & 20 & - & -- & - & -- & - & 20 & 2 \\
\hline TOTML & & & & & & 34 & 56 & - & $\cdots$ & $\cdots$ & - & 110 & 6 \\
\hline \multicolumn{14}{|l|}{ melas } \\
\hline $\begin{array}{l}\text { aO post VILAse } \\
\text { TotM }\end{array}$ & $13000-14600$ & 252 & $\mathbf{m}$ & wo & $m$ & $\begin{array}{l}20 \\
20\end{array}$ & $\begin{array}{l}10 \\
10\end{array}$ & $\ddot{-}$ & $\overline{-}$ & $\ddot{-}$ & $=$ & $\begin{array}{l}30 \\
30\end{array}$ & -- \\
\hline 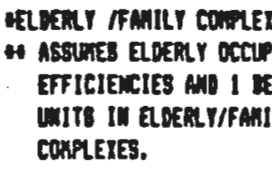 & & & & & & & & & & & & & \\
\hline
\end{tabular}


맥.

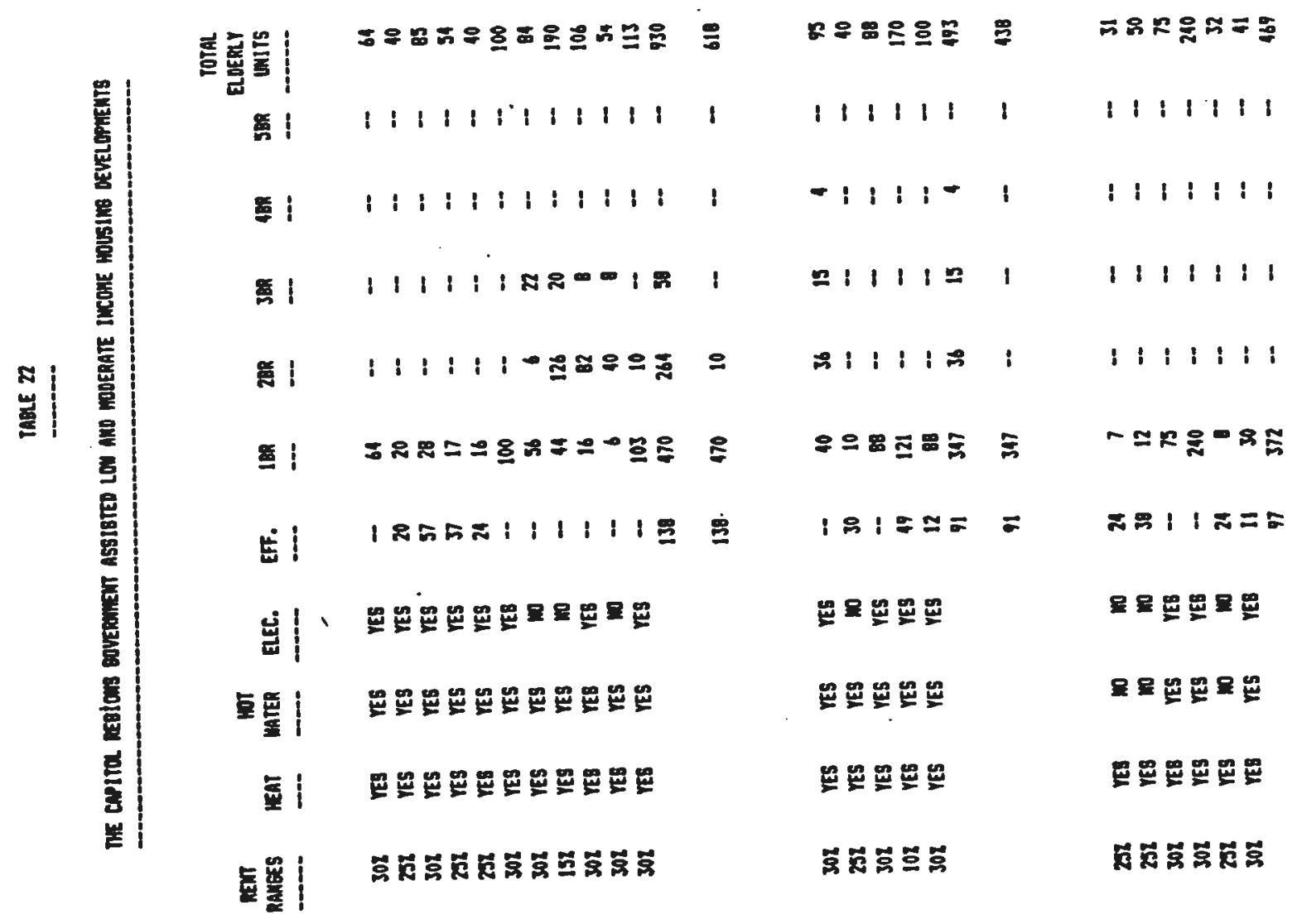

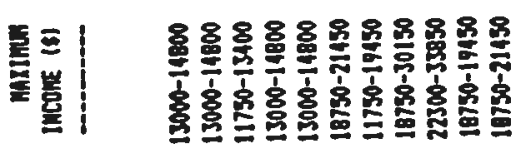

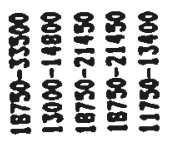

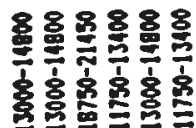

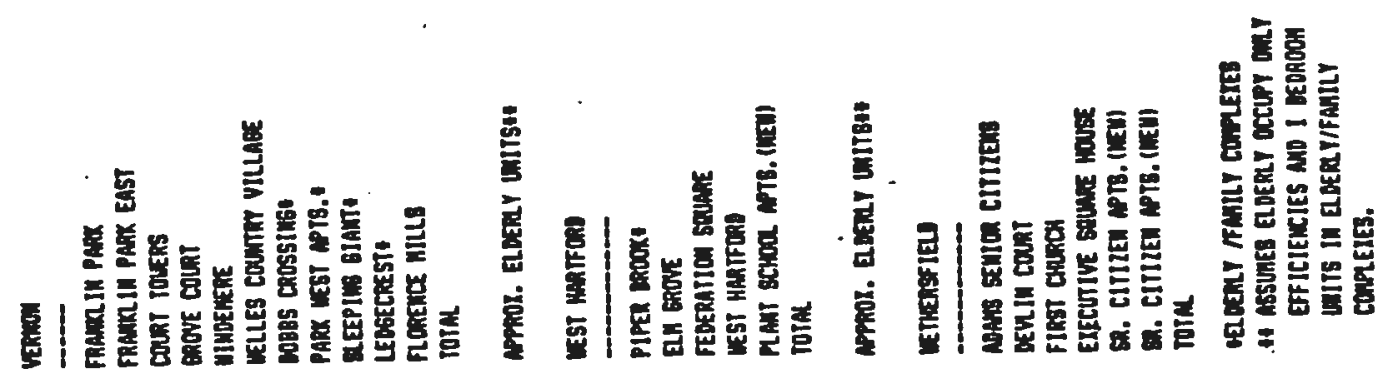




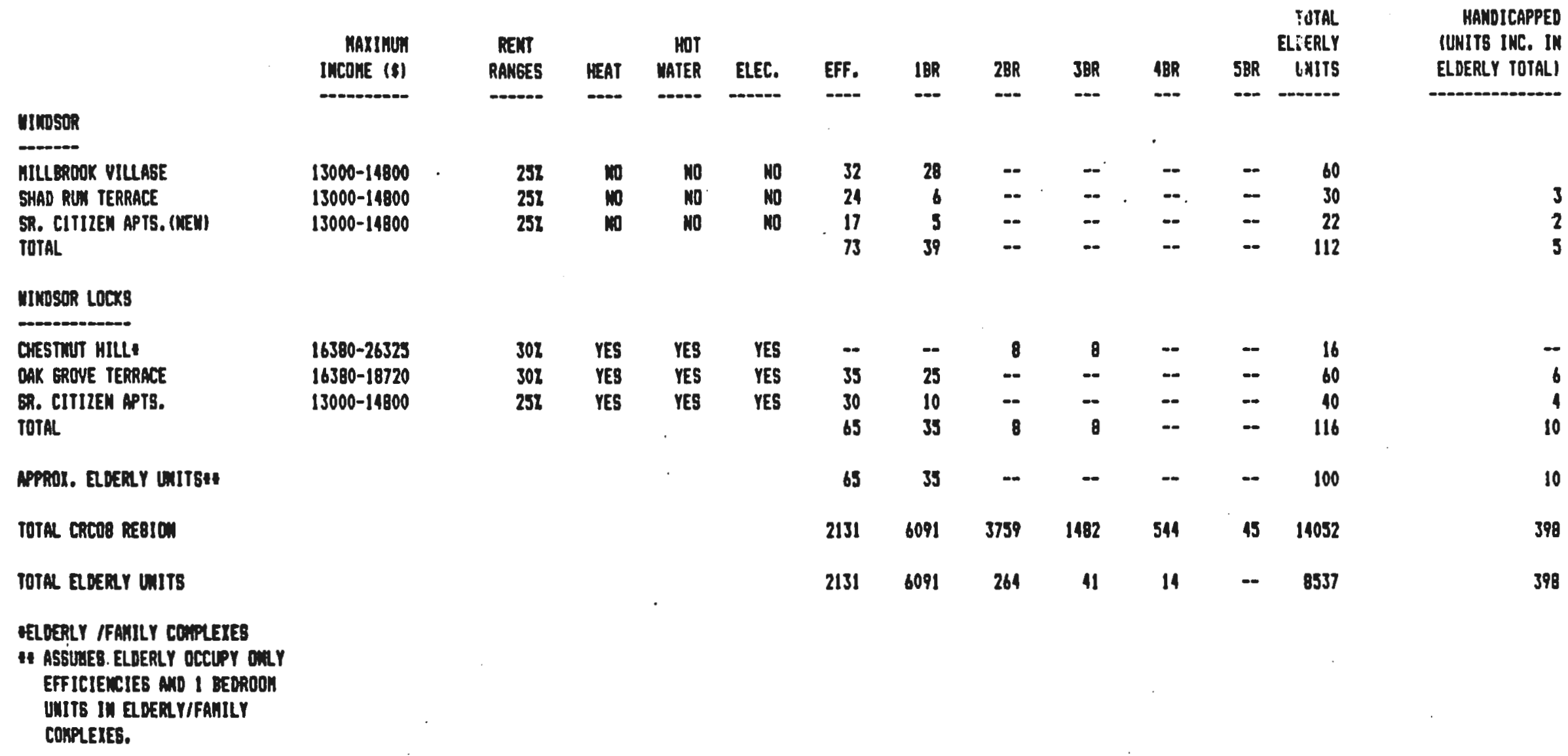

SOLRE: 1984 CRCOB HOUSIMB OPPORTLMITIES, LOCAL HOUSIWG AUTHORITIES. 
number of persons occupying the unjt. For exainple, the elderly development of Hop River Homes in the town of Andover has a maximum income range of $\$ 11,750$ for 1 person and $\$ 13,400$ for 2 people, while shea Garden in the town of East Hartford has as its maximum income range $\$ 13,700-\$ 15,600$.

\title{
COST
}

\author{
* Rent ranges for most of these elderly and \\ elderly/family low and moderate income housing \\ developments are $25 \%-30 \%$ of the elderly resident's \\ income. \\ *In the majority of these housing complexes, the rent \\ covers the utility expenses of heat, hot water, and \\ electricity.
}

\section{DISTRIBUTION}

* The distribution of elderly units within the Capitol Region by type of community (i.e., Center City, Inner Core, Inner Suburbs, and Outer suburbs) shows the Center City, which is the city of Hartford, to contain $36.7 \%$ of all of the Region's elderly units, with the Outer Suburbs, Inner Core, and Inner Suburbs containing $23.8 \%$, $21.8 \%$, and $17.7 \%$ of the region's elderly units respectively. (See Map 7.)

* A breakdown of the Capitol Region's elderly units by city and town shows the city of Hartford to contain the greatest number of elderly units, 3,133 , which is $36.7 \%$ of the Region's elderly units. Other cities and towns with substantial numbers of elderly units are: the town 
of East Hartford ( 890 units or $10.4 \%$ of the region's elderly units), the town of Vernon (6.18 units or $7.2 \%$ of the Region's elderly units), the town of Manchester ( 533 units of $6.2 \%$ of the region's elderly units), the town of wethersfield (469 units or $5.5 \%$ of the Region's elderly units), the town of West Hartford (438 units or $5.1 \%$ of the region's elderly units), and the town of Blooinfield (422 units or $4.9 \%$ of the region's elderly units). (See Table 23 and Map 7.)

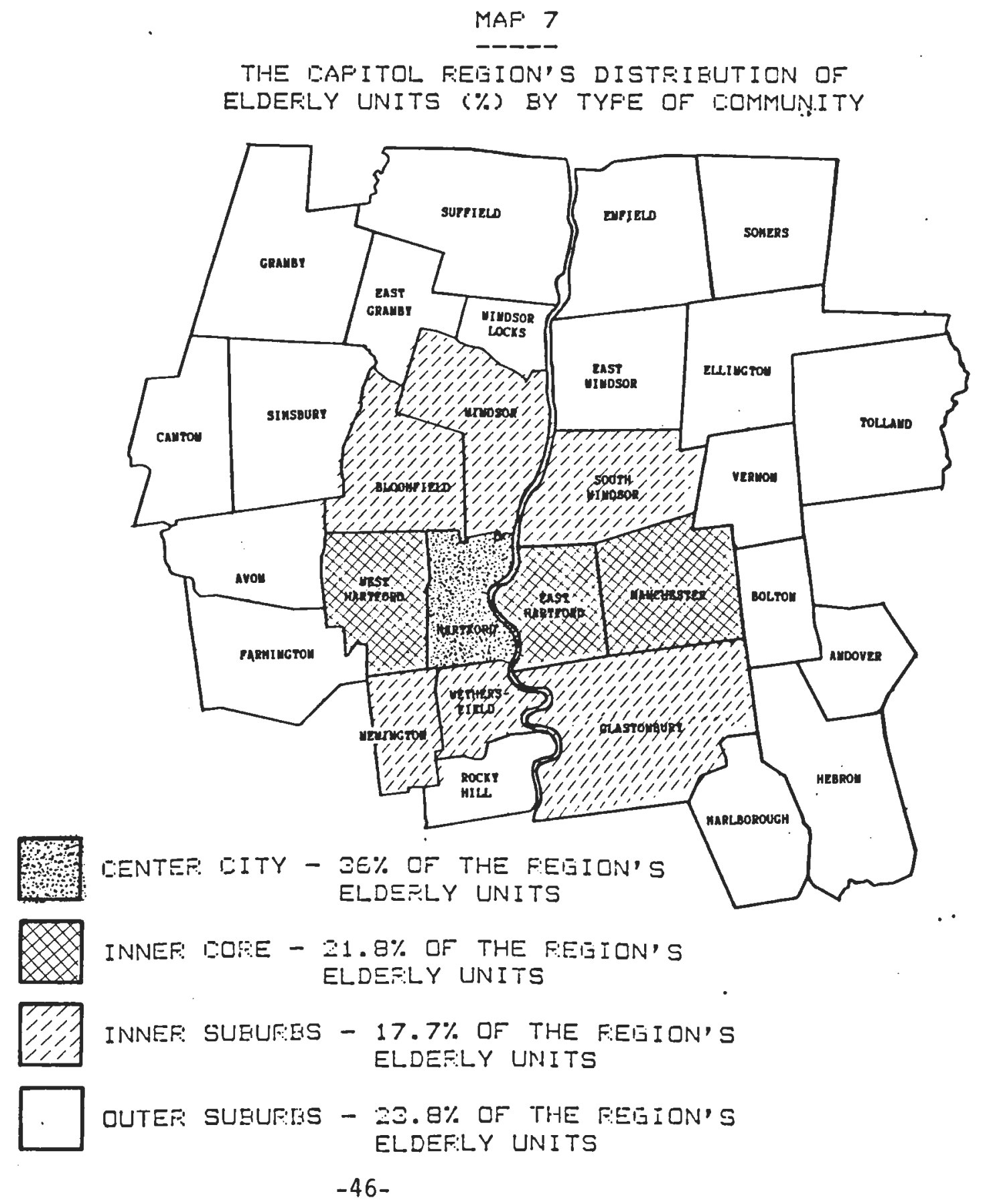


COAPOSITION OF THE CAPITOL REGION'S ELDERLY HOUSING UNITS

UNITS AS

TOHN EFF. 1 BR. 2 8R. 3 BR. 4 BR. 5 BR. UNITS CAPPED CRCO8

\begin{tabular}{|c|c|c|c|c|c|c|c|c|c|}
\hline AKDOVER & 0 & 24 & 0 & 0 & 0 & 0 & 24 & 3 & 0.3 \\
\hline AVON & 0 & 39 & 0 & 0 & 0 & 0 & 39 & 4 & 0.5 \\
\hline BLOOMF IELD & 62 & 338 & 9 & 12 & 1 & 0 & 422 & 30 & 4.9 \\
\hline BOLTON & 0 & 0 & 0 & 0 & 0 & 0 & 0 & 0 & 0.0 \\
\hline CAMTON & 30 & 65 & 19 & 0 & 0 & 0 & 114 & 9 & 1.3 \\
\hline EAST GRANBY & 21 & 45 & 6 & 0 & 0 & 0 & 72 & 4 & 0.8 \\
\hline EAST HARTFORD & 170 & 720 & 0 & 0 & 0 & 0 & 890 & 37 & 10.4 \\
\hline EAST HIMDSOR & 97 & 57 & 0 & 0 & 0 & 0 & 154 & 3 & 1.8 \\
\hline ELLINGTON & 20 & 98 & 0 & 0 & 0 & 0 & 118 & 0 & 1.4 \\
\hline ENFIELD & 120 & 177 & 0 & 0 & 0 & 0 & 297 & 10 & 3.5 \\
\hline FARHINGTON & 38 & 76 & 0 & 0 & 0 & 0 & 114 & 4 & 1.3 \\
\hline GLASTONBURY & 142 & 138 & 0 & 0 & 0 & 0 & 280 & 8 & 3.3 \\
\hline GRANBY & 0 & 10 & 20 & 0 & 0 & 0 & 30 & 0 & 0.4 \\
\hline HARTFORD & 499 & 2444 & 148 & 29 & 13 & 0 & 3133 & 122 & 36.7 \\
\hline HEBRON & 19 & 6 & 0 & 0 & 0 & 0 & 25 & 3 & 0.3 \\
\hline MANCHESTER & 158 & 323 & 52 & 0 & 0 & 0 & 533 & 25 & 6.2 \\
\hline HARLBOROUGH & 0 & 0 & 0 & 0 & 0 & 0 & 0 & 0 & 0.0 \\
\hline MEUINGTON & 77 & 120 & 0 & 0 & 0 & 0 & 197 & 17 & 2.3 \\
\hline ROCKY HILL & 30 & 10 & 0 & 0 & 0 & 0 & 40 & 4 & 0.5 \\
\hline SIMSBURY & 49 & 49 & 0 & 0 & 0 & 0 & 98 & 0 & 1.1 \\
\hline SOMERS & 39 & 15 & 0 & 0 & 0 & 0 & 54 & 0 & 0.6 \\
\hline SOUTH HINDSOR & 22 & 8 & 0 & 0 & 0 & 0 & 30 & 0 & 0.4 \\
\hline SUFFIELD & 54 & 56 & 0 & 0 & 0 & 0 & 110 & 6 & 1.3 \\
\hline TOLLAND & 20 & 10 & 0 & 0 & 0 & 0 & 30 & 0 & 0.4 \\
\hline VERNON & 138 & 470 & 10 & 0 & 0 & 0 & 618 & 27 & 7.2 \\
\hline HEST HARTFORD & 91 & 347 & 0 & 0 & 0 & 0 & 438 & 23 & 5.1 \\
\hline METHERSFIELD & 97 & 372 & 0 & 0 & 0 & 0 & 469 & 44 & 5.5 \\
\hline $\begin{array}{l}\text { UINDSOR } \\
\text { WINDSOR LOCKS }\end{array}$ & $\begin{array}{l}73 \\
65\end{array}$ & $\begin{array}{l}39 \\
35\end{array}$ & $\begin{array}{l}0 \\
0\end{array}$ & $\begin{array}{l}0 \\
0\end{array}$ & $\begin{array}{l}0 \\
0\end{array}$ & $\begin{array}{l}0 \\
0\end{array}$ & $\begin{array}{l}112 \\
100\end{array}$ & $\begin{array}{r}5 \\
\cdot 10\end{array}$ & $\begin{array}{l}1.3 \\
1.2\end{array}$ \\
\hline CRCOG & 2131 & 6091 & 264 & 41 & 14 & 0 & B541 & 398 & 100.0 \\
\hline
\end{tabular}

SOURCE:1984 HOUSING OPPORTUNITIES CRCOG.

*Analysis of the distribution of unit type (i.e.. efficiency, 1 bedroom, 2 bedroom) by city and town throughout the Capitol Region shows $71 \%$ of the region's elderly units to be 1 bedroom, with the majority $(2,444$ 
units or $40 \%$ of all 1 bedroom units within the Region) of these units to be located within the city of

Hartford. Other communities with signiticant numbers of 1 bedroom units are the town of East Hartford (720 units), Vernon (470 units), Wethersfield (372 units), West Hartford ( 347 units), Manchester (323 units) and Bloomfield (338 units). (See Map 8.)
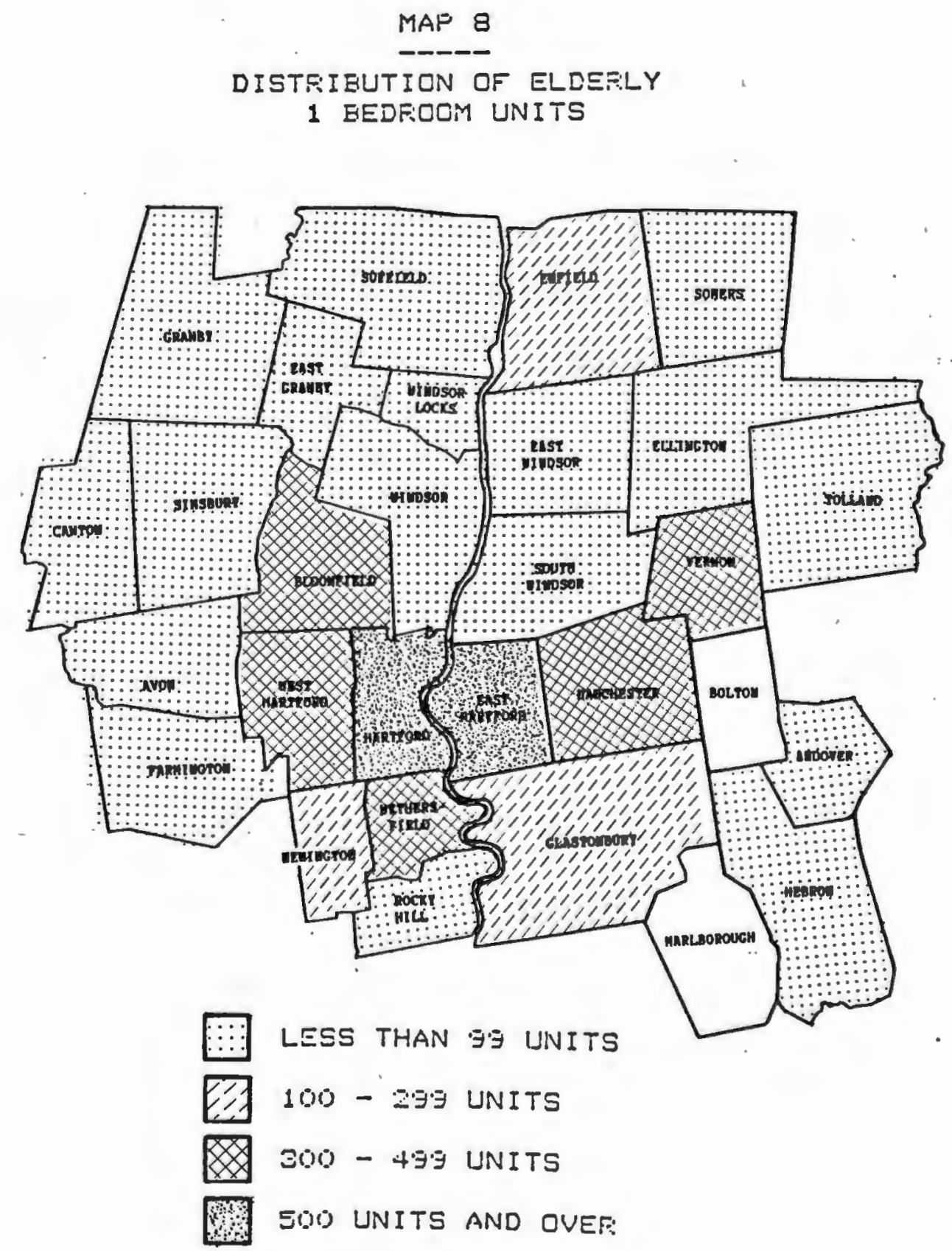
Efficiencies are the second most abunclant type of elderly housing unit, accounting for $25 \%$ of all elderly units within the Capitol Region. Once again, the city of Hartford contains the greatest number of efficiency units (499 units or $23.4 \%$ of a 1.1 efficiency units within the Region). Other cities and towns with significant nurinsis of efficiency units are: East Hartford (170 units), Manchester (158 units), Glastonbury (142 units), Vernon (138 units), and Enfield 120 units). (See Map 9.)
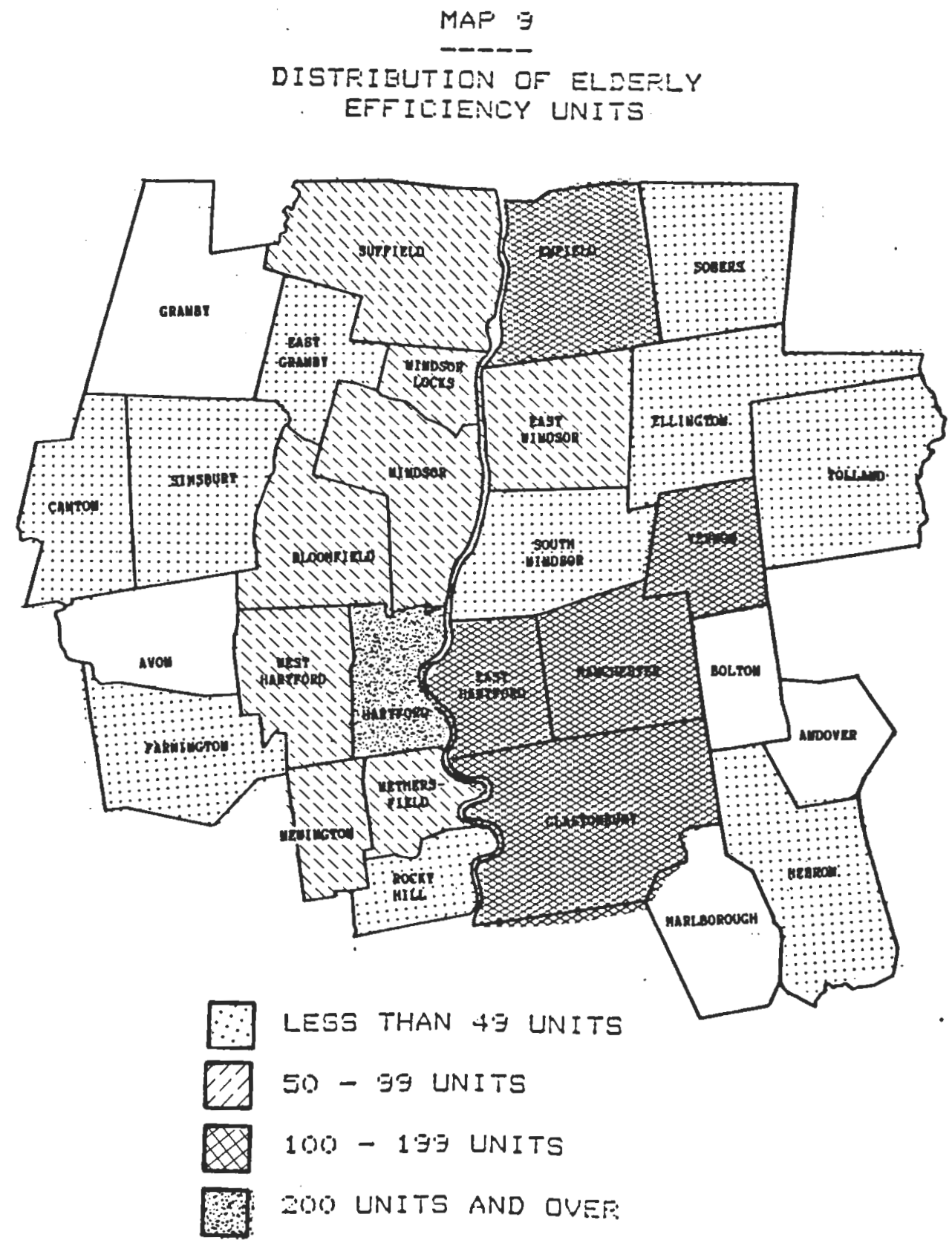
If an elderly person were interested in a 2, 3 or 4 bedroom low or moderate incone housing unit he/she would be linited not only by availability (the capitol Region has a small number of these larger units for the elderly), but also by location (only a few Capjtol Region towns have these large units). For example, if an elderly person wantad a 2 bedroom unit he/she would find: there are only 204 of these larger units, located in 7 of the Capitol Region's 29 cities and touns, with the city of Hartiord containing over $56.1 \%$ of all 2 bedroom units. If a 3 or 4 bedroom unit were desired, availability would be limited to 41 and 14 units respectively, all located within the city of Hartford and the town of Bloomfield.

It should be noted that 2,3 , and 4 bedroom units total are For only those "exclusively elderly" low and moderate income housing complexes, since it is assumed $2,3,4$ and 5 bedroom units in "elderly/family" developments would most likely be occupied by fanilies, as opposed to elderly. In reality, there may be a few of these larger units in elderly/family complexes occupied by the elderly, but the number of elderly occupying these units is miniscule according to the Region's municipal housing authorities. (See Maps $10,11,12$ ).

* Comparing the distribution of the Capitol Region's 398 handicapped units (most are 1 bedroom units), one finds the city of Hartford to contain 122 units or $30.7 \%$ of a.l handicapped units in the Region. Other towns with sizeable numbers of handicapped units are wethersfield, East Hartford, Blooinfield, Vernon, Manchester and west Hartford with 4.4, 37, 30, 27, 25 and 23 units respectively. In contrast, the towns of Granby, Simsbury, Somers, 


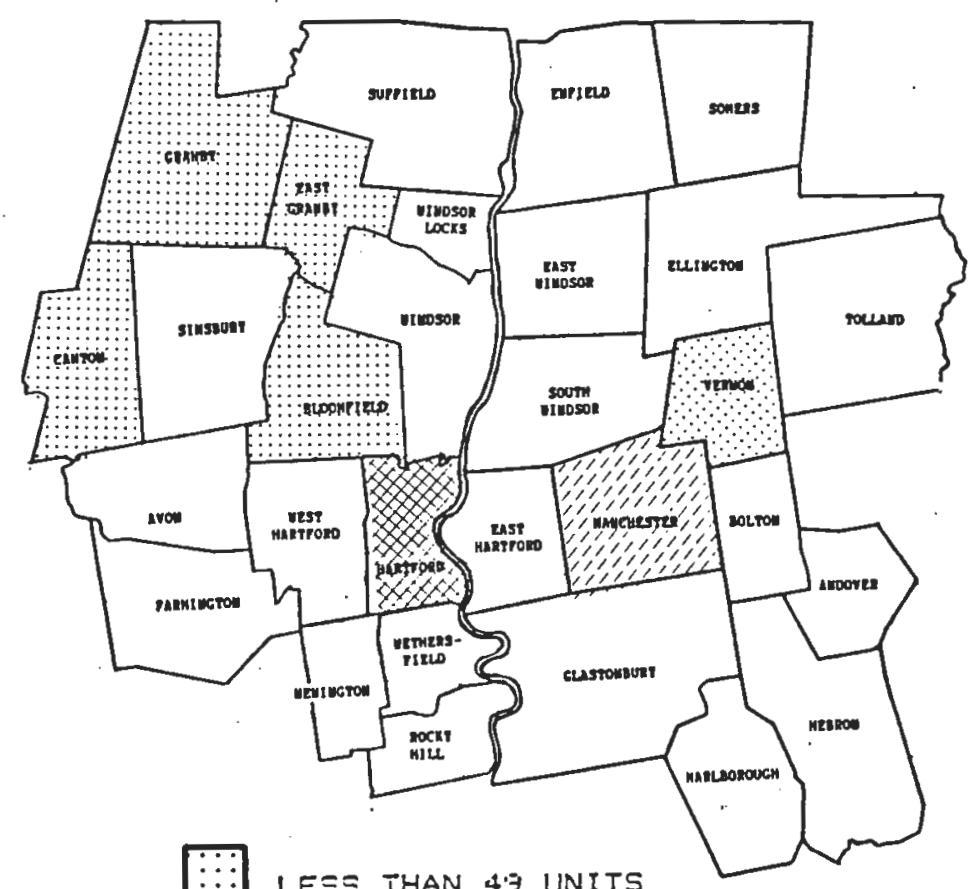

MAP II

MAP 1

DISTFIEUTICN CF EIEESIYY 3 BEDEUEM UNITS

E'] so - 93 UNITS

\& 100 UNITS AND OVEE
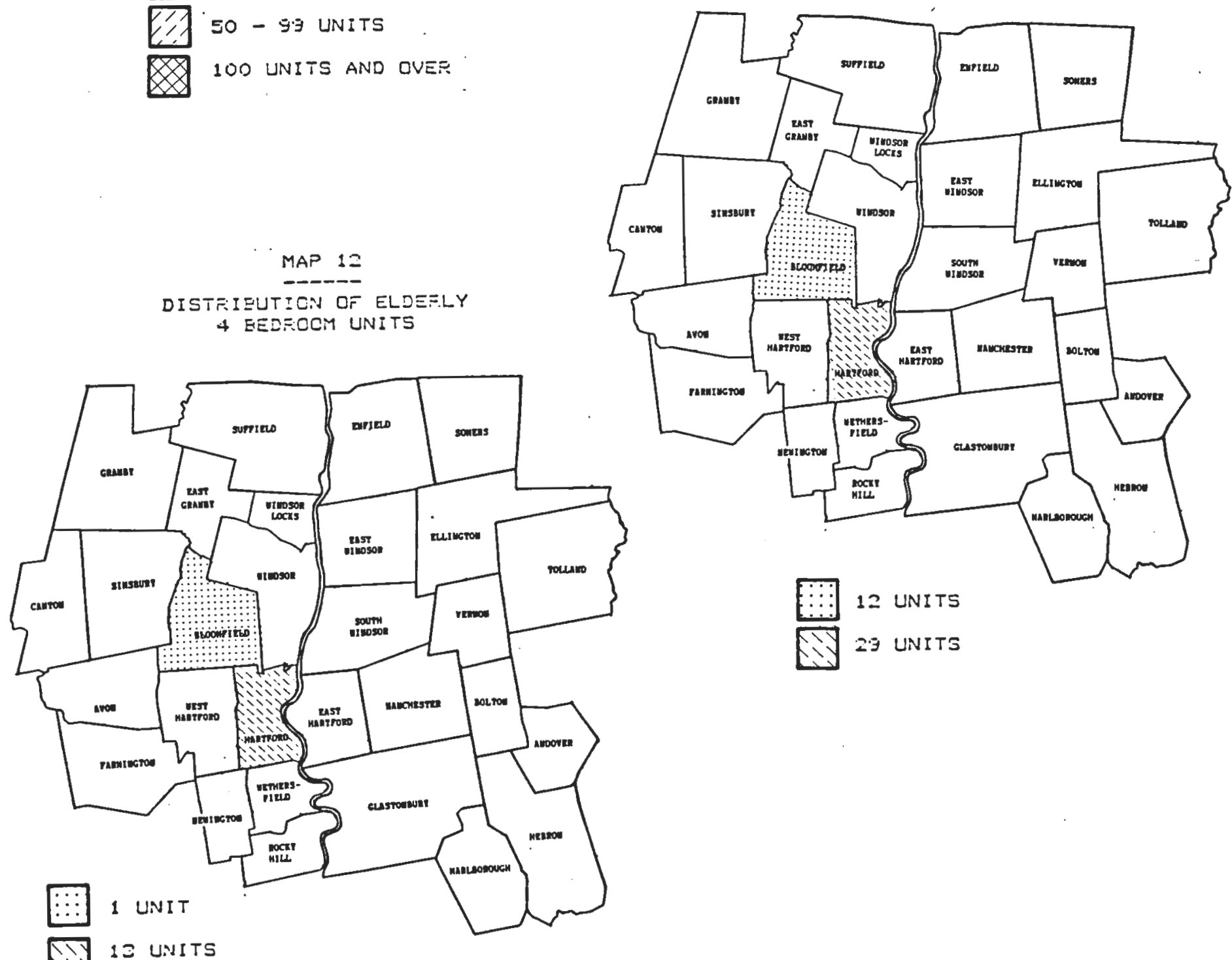

E:: 12 UNITS

EIV 29 UNITS 
South windsor. Tolland, and Ellington offer low and moderate income housing to the elderly, but none of their units are handicapped accessible. (See Table 23 and Map 13.)

MAF 13
THE DISTFIEUTION OF ELDEFIYY
HAUUICAFFED ACI:ESSIELE UNITS

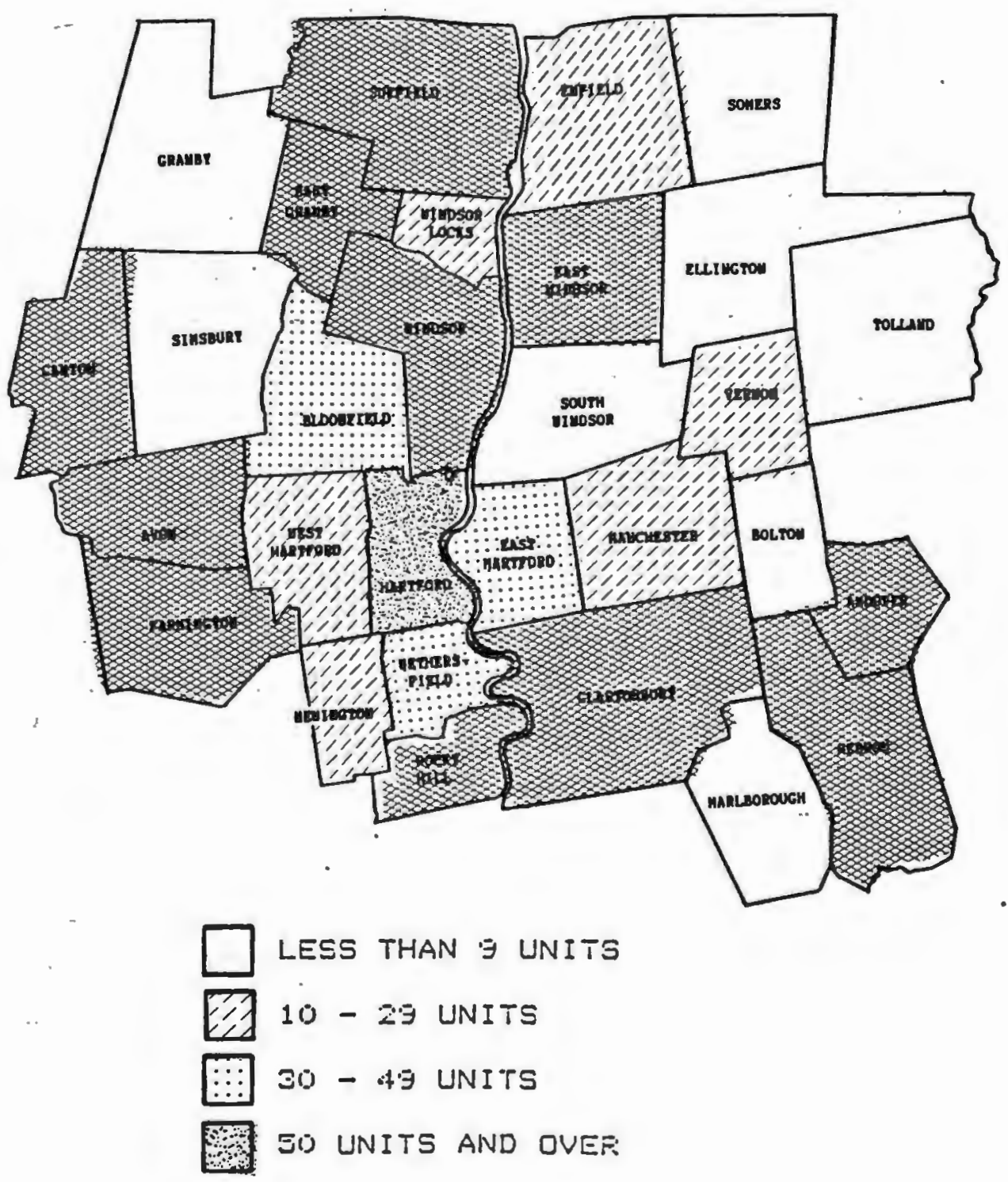


The Federal Government's Section 8 Rental Assistance Program is designed to enable people to afford decent housing within the private housing market without spending more than $30 \%$ of their adjusted gross income on rent and utjlitiss. This program is intended to alleviate some of the financial burdens on the low and inoderate income renter, as well as provide an alternative to the local. government assisted low and moderate income developments.

The Section 8 Rental Assistance Prograin works the following way: The potential participant's adjusted gross income must be less than those listed in Table 24 to be eligible for section 8 rental assistance. Low income families, elderly and handjcapped individuals who qualify are issued "Certificates of Participation." These certificates can be used only in the

TABLE 24

INCOME LIMITS FOR SECTION 8 RENTAL ASSISTANCE

\begin{tabular}{lr} 
NUMBER OF & MAXIMUM INCOME \\
PERSONS & \multicolumn{1}{c}{ (ADJUSTED GROSS INC.) } \\
PER FAMILY & $\$ 11,750$ \\
\hline ONE & $\$ 13,400$ \\
TWO & $\$ 15,050$ \\
THREE & $\$ 16,750$ \\
FUUR & $\$ 18,100$ \\
FIVE & $\$ 19,450$ \\
SIX & $\$ 20,750$ \\
SEVEN & $\$ 22,100$ \\
EIGHT & $\$ 120$
\end{tabular}

SOURCE: CRCOG, AND CONNECTICUT DEPARTMENT OF HOLSING. 
city or town in which the certificate has been issued. Those participants issued certificates are then responsible for finding an apartment within the private housing market charging a rent that falls within the limits set by the local housing authority. (See Table 25.) Once an apartment is found, the owner or manacer of the unit must agree to participate in the piogram. If the apartment then passes inspection by the local housing authority, the owner or manager signs a lease with the participant and the local housing authority.

TABLE 25

1985 FAIR MARKET RENTS FDR SECTION 8 RENTAL ASSISTANCE

\begin{tabular}{|c|c|c|c|}
\hline CRC & & \multicolumn{2}{|c|}{ EXCEPTIONS } \\
\hline $\begin{array}{l}\text { RENT PER } \\
\text { MDNTH }\end{array}$ & $\begin{array}{l}\text { UNIT } \\
\text { TYPE }\end{array}$ & $\begin{array}{l}\text { BLODMF IELD, } \\
\text { GLASTONBURY }\end{array}$ & MANCHESTER \\
\hline$\$ 305$ & EFF. & $\$ 305$ & $\$ 351$ \\
\hline$\$ 365$ & 1 BR. & $\$ 366$ & $\$ 438$ \\
\hline$\$ 431$ & 2 BR. & $\$ 517$ & $\$ 517$ \\
\hline$\$ 533$ & 3 BR. & $\$ 639$ & $\$ 613$ \\
\hline$\$ 591$ & 4 BR. & $\$ 709$ & $\$ 680$ \\
\hline
\end{tabular}

\section{SOURCE: CONNECTICUT DEPARTMENT OF HOUSING AND CRCOG LDCAL HOUSING AUTHORITIES.}

At the present time, 15 of the Capitol Region's 29 cities and towns participate in the Section 8 Rental Assistance Program. Since 1980, the number of elderly in the Capitol Region using the section 8 program totalled 793 (includes elderly handicapped). (See. Table. 20 and Map 14.) As one would expect, the city of Hartford has the greatest number of elderly section 8 participants, 365, which accounts for $46 \%$ of the Region's elderly participating in this program over the past five years. The only other community which has shown a substantial number of elderly participating in the Section 8 prograin is the toun of West Hartford, with 137 elderly participants. 
TABLE 26

CRCOG SECTION \& PARTICIPANTS

\begin{tabular}{lr} 
& ELDERLY \\
TOWN & ON PROGRAM \\
\hline BLOOMF IELD & 25 \\
CANTON & 3 \\
EAST HARTFORD & 8 \\
ENF IELD & 26 \\
FARMINGTON & 29 \\
GLASTONEURY & 10 \\
HARTFORD & 365 \\
MANCHESTER & 69 \\
NEWINGTON & 10 \\
SOUTH WINDSOR & 2 \\
VERNON & 33 \\
WEST HARTFORD & 137 \\
WETHERSF IELD & 19 \\
WINDSOR & 25 \\
WINDSOR LOCKS & 32 \\
TOTAL & \\
&
\end{tabular}
SOURCE: CRCOG, LOCAL HOUSING AUTHORITIES, AND THE CONNECTICUT DEPARTMENT OF HOUSING.
MAF 14
TOWNS FAFTIEIFATING IN THE BEOTIN FENTAL ASSISTANIEE FEOEEAMM

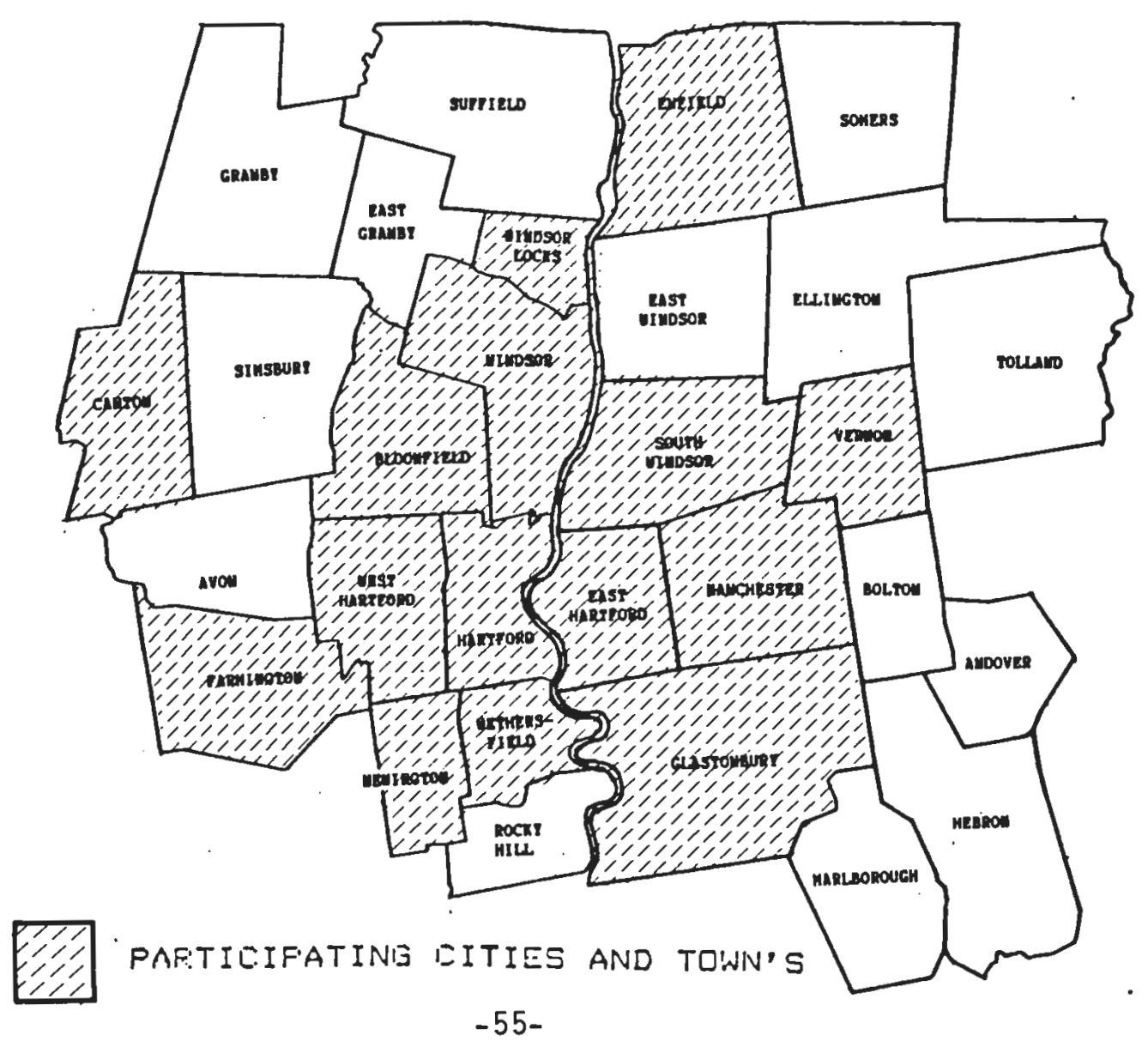


In order to determine the availabijity of affordable rental. units in the private market, the Connecticut Department of Housing (DOH) in 1983 conducted a survey of the four largest urban housing authorities which administer the section 8 program, as well as $D O H$ field offices which administer the program in smaller commuties. The Hartford Holsing Authority and the DOH rental assistance field office serving some of the smaller communities around Hartford were part of this survey (Hartford's geographical survey area does not exactly comrespond to the capitol Region). As shown in Table 27 , the results of this survey indicate that most of the elderly and families in the Hartford area who qualified for the Section 8 Rental Assistance Program and obtained certificates of Participation could not find an available and affordable unit to occupy. The survey concluded that "out of the total number of households applying for rental assistance (elderly and families) in the private market only a few were able to find a decent, safe and sanitary unit.

Unfortunately, there is no accounting for those households who have? been turned away because of prohibitively long waiting lists at all the section 8 offices. 15

\section{WAITING LISTS}

According to the local municipal housing authorities who administer both the Government Assisted Low and Moderate Income Housing Developments and the Section 8 Rental Assistance Program, there are waiting lists of at least 1 year or more for both programs. This current state of affairs points out the need for additional housing units in the public and private sector to meet an 
ever-growing demand by the Capitol "Region's low and moderate income elderly and farilies. The issue of supply and denand of subsidized units for the elderly in the present and future will be addressed more fully in the next chapter.

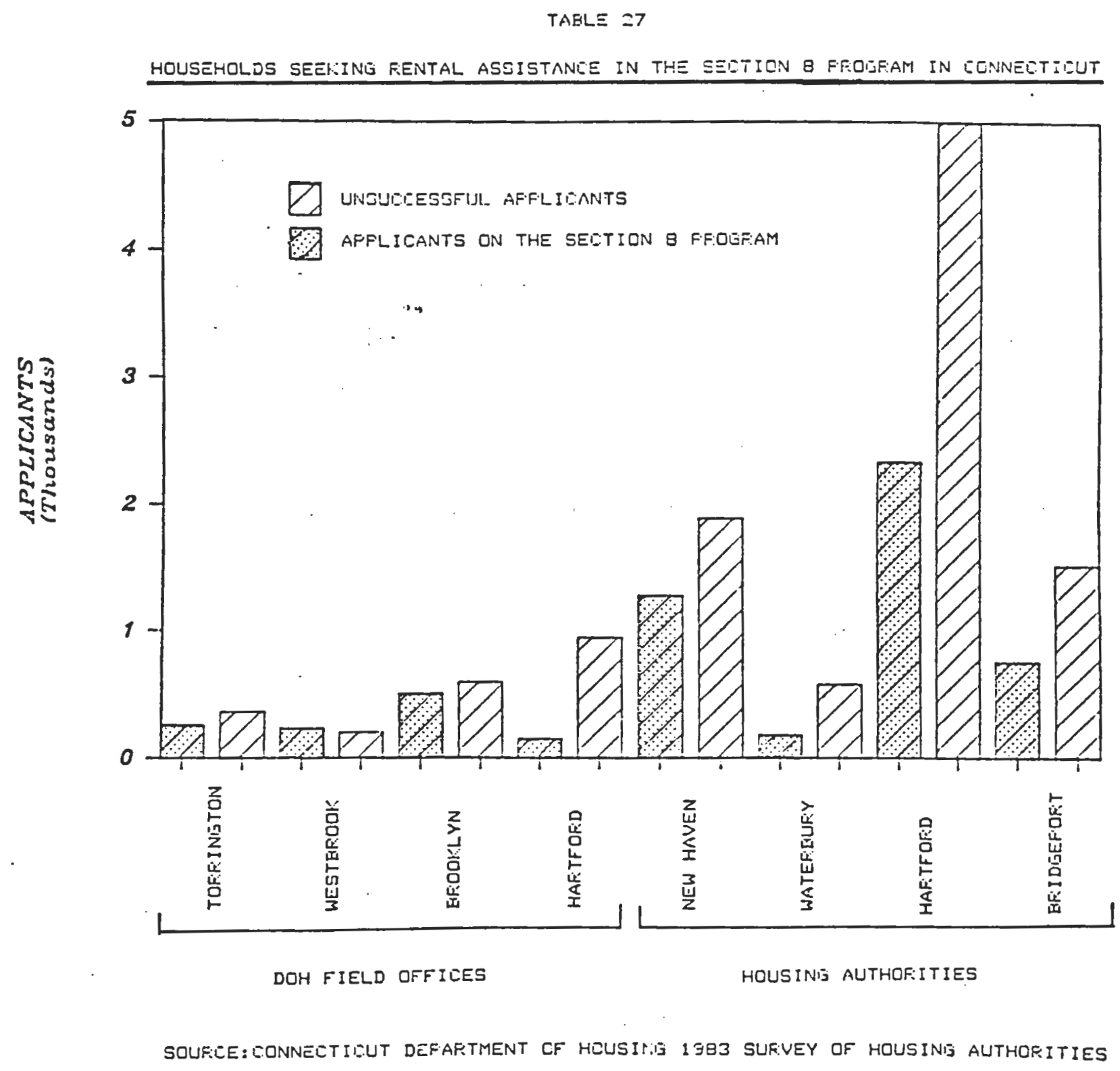


* The Capitol Region offers the low and moderate income elderly two subsidized prograins to ineet their housing needs: the Government Assisted Low and Moderate Income Housing Developments and the Federal Governinent's Section 8 Rental Assistance Program.

* The more populated cities and towns in the Capitol Region offer the greatest subsidized housing opportunities, i.e., numbers of units, types of units.

* The majority of elderly units within the Capitol Region's public housing developments are either 1 bedroom units or efficiencies with few larger units available.

* Rent ranges for subsidized private (Section 8) and public units are $25 \%-30 \%$ of the elderly's income, which in most cases includes heat, hot water and electricity.

* The elderly's incone eligibility requirements for a subsidized unit varies by town and complex, but on average range from $\$ 11,750-\$ 21,450$ for public units, and $\$ 11,750-\$ 22,100$ for the private sector units (Section 8 ), depending on the number of persons occupying, the apartment.

* Elderly renters desiring specific types of units (i.e., two bedrooms, handicapped accessibility) are limited to certain towns due to the uneven distribution of all types of units through the Capitol Region.

* The city of Hartford contains the greatest percentage of the Capitol Region's elderly units and types of units (including handicapped accessable units).

* The Federal Governinent's Section 8 Rental Assistance program is only offered in 15 of the Capitol Region's 29 cities and towns.

* There are 793 elderly persons using the section 8 Rental Assistance Prograrn in the Capitol Region.

* At the present time, $4.6 \%$ of the Capitol Region's Section 8 participants reside in the city of Hartford.

* The fair market rents for the Section 8 Rental Assistance Program range from $\$ 305-\$ 591$ per month (including utilities), depending on the number of bedrooins. 
* There were many more "èderly persons eligible for the Section 8 Rental Assistance program that were issued certificates of Participation but were unable to find apartments within the prescribed rental limits that were decent, safe and sanitary.

* The demand for subsidized housing (public and private) urits by the elderly far outweighs the current supply within the capitol Region. At the present time there are one year waiting lists on both the subsidized Low and Moderate Inromr Housing Developments and the Section 8 Rental Assistance Program. 


\section{CHAPTER THREE}




\section{THE PRESENT AND FUTURE NEEDS F" FOR SUBSIDIZED ELDERLY HOUSING}

\section{IN THE CAPITAL REGION}

This chapter will discuss the current need for additional. units of elderly subsidized housing in the capitol Region, as well as the demand for this type of housing in the future.

\section{PRESENT NEED}

Analysis of al. available data reveals the current demand for subsidized elderly housing units in the capitol Region by far exceeds its supply. The following supports this conclusion:

* As mentioned in the previous chapter, at the present time, there is at least a one-year waiting period for both the subsidized Low and Moderate Income Housing Developments and the Section 8 Rental Assistance Program.

* While one year waiting periods appear to be the norin for both subsidized elderly housing programs, one finds the number of section 8 rental assistance participants remaining constant and the number of low and moderate income housing units for the elderly to be declining. As shown in Table 28, (also see Table 22) since 1984 the number of subsidized elderly units has dropped by $18.4 \%$, from 4.57 units built in 1984 to only 386 units built in 1985. This decline is expected to continue due to the drop in federal funding for such projects. 
NEW LOW AND MODERATE INCOME HOUSING DEVELOPMENTS FOR THE ELDERLY IN THE CAPITOL REGION

\begin{tabular}{|c|c|c|c|c|c|}
\hline \multirow[b]{2}{*}{ YEAR } & \multirow{2}{*}{$\begin{array}{c}\text { NUMBER QF } \\
\text { COMPLEXES } \\
\text { BUILT }\end{array}$} & \multicolumn{2}{|c|}{ UNIT TYPE } & \multirow[b]{2}{*}{$\begin{array}{l}\text { TOTAL } \\
\text { UNITS }\end{array}$} & \\
\hline & & EFFICIENCIES & 1 BEDROOM & & $\begin{array}{l}\text { UNITS (INC. } \\
\text { IN TOTAL) }\end{array}$ \\
\hline 1985 & 11 & 197 & 199 & 386 & 45 \\
\hline 1984 & 6 & 108 & 349 & 457 & \\
\hline
\end{tabular}

SQURCE: 1984, 1983 CRCOQ HOUSING OPPORTUNITIES, LOCAL HOUSING AUTHORITIES.

* There is a large number of elderly persons within the Region who are not participating in either the Section 8 Rental Assistance Program nor reside in a federal gouemment Low and Moderate Income Housing Development, and are living in "substandard" housing. According to the U.S. Departinent of Housing and Urban Development, in 1981 there were 13,642 elderly households living in substandard housing units within Hartford County. (See Table 29) (Hartford County, comprising only a part of the Capitol Region, includes the following Capitol. Region citjes and towns:

TABLE 29

1991 ESTIMATED NUMBER OF LOW AND MODERATE INCOME ELDERLY HOUSEHDLDS LIVING IN SUBSTANDARD HOUSING CONDITIONS

COUNTY

HARTFORD

FAIRFIELD

LITCHF IELD

MIDDLESEX

NEW HAVEN

NEW LONDON

TOLLAND

WINDHAM

TOTAL

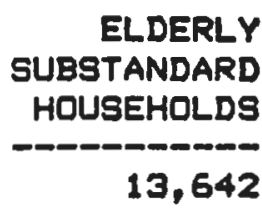

10,641

1,986

1,359

13,457

2,937

739

1,622

46,383
TOTAL SUBSTANDARD HOUSEHOLDS

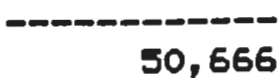

37,768

5,557

4,943

48.116

13,498

4,345

5,052

169,947
ELDERLY SUB. HH AS A \% OF TQTAL SUB. HH

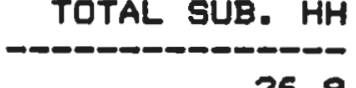

26. 9

28. 2

35.7

27.5

28. 0

21.8

17.0

32.1

27.3

SQURCE:U.S. DEPARTMENT OF HOUSING AND URBAN DEVELOPMENT 
Hartford. East Hartford, West Hartford, Manchester, Windsor, Windsor Locks, Glastonbury, Granby, Avon, Bloomfield, Canton, East Granby, East Windsor. Enfield, Farmington, Wethersfield, Rocky Hill, Simsbury, South Windsor, Suffield, Marlborough, and Newington). This accounted for $20.9 \%$ of all substandard housing unjts in Hartford county. These are elderly households who need a decent, safe and sanitary place to live in addition to those elderly residents currently participating in both subsidized housing programs.

* As stated in the connecticut report on Housing "the issue of financial burden may be the most critical aspect of determining housing need." 6 Analyzing the Capitol Region's 1980 elderly family income, one finds the following: (See Table 30. )

* $25.4 \%$ or 0.355 elderly farnilies in the Capitol Region showed incoines below $\$ 10,000$ and $47.4 \%$ or 11,859 elderly families showed incomes below $\$ 15,000$. (Families consist of 2 or more persons related by blood, inarriage or adoption living together in the same household.)

* The elderly median fanily income for the capitol Region in 1980 wass $\$ 15,634$.

* 10 of the capjtol Region's 29 cities and touns had elderly median fanily incomes below those of the entire Region. These cities and towns are: Vernon $(\$ 12,532)$, 
THE CAPITOL REGION'S ELDERLY FAMILIES BY INCOHE

TOHN

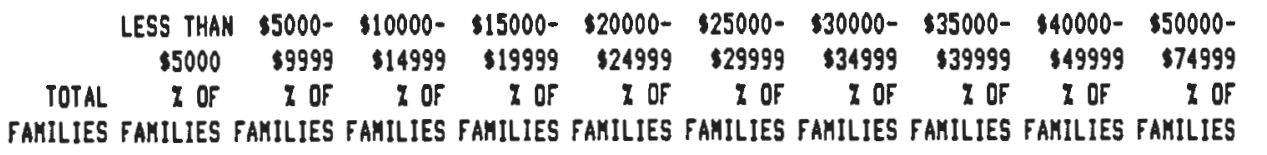

\$75000+ MEDIAN

I OF

FAMILIES

FAMILY

INCOME (\$)

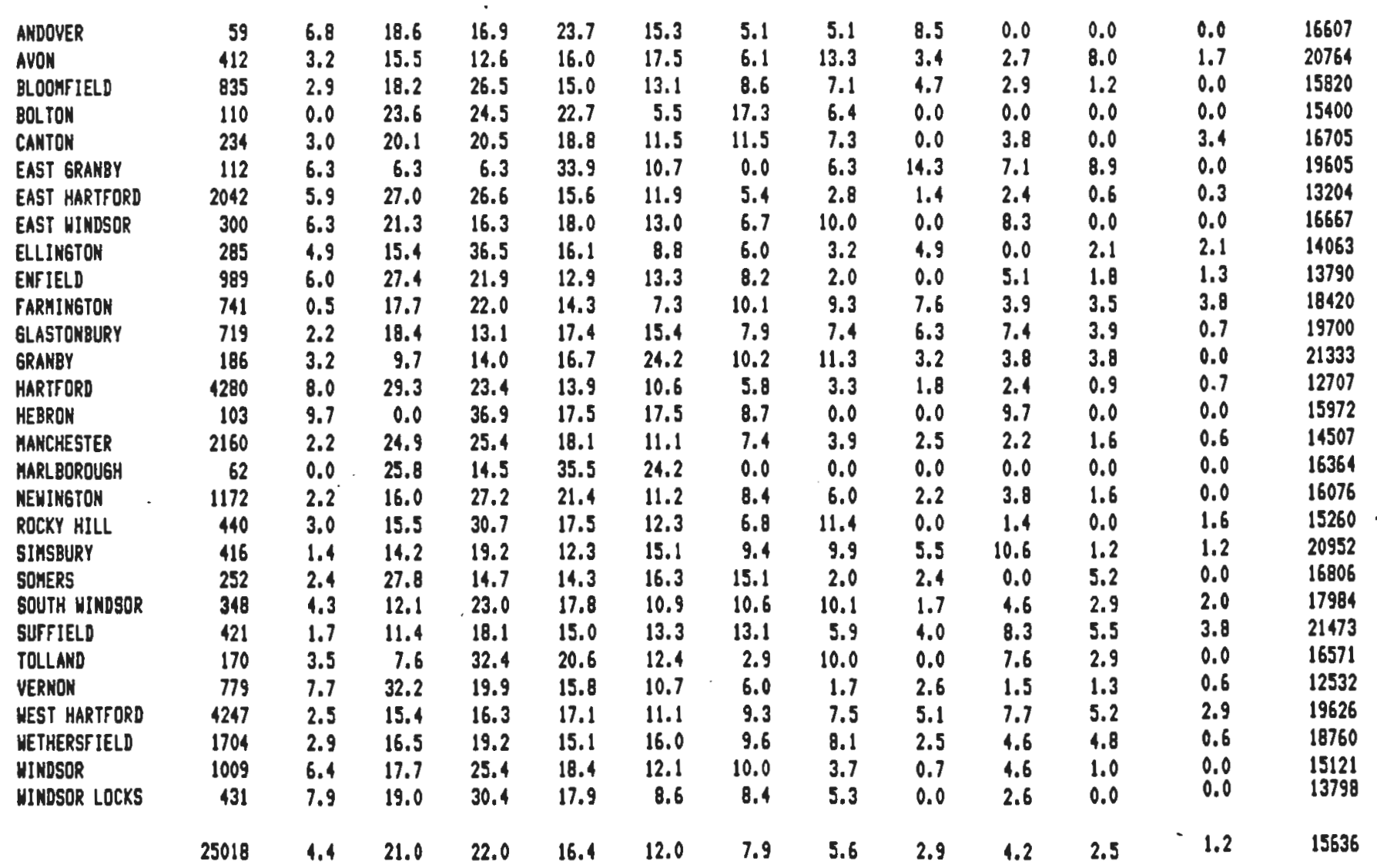

SOURCE 1980 CENSUS STF4

\footnotetext{
Hartford $(\$ 12,707)$, East Hartford $(\$ 13,204)$, Enfield

$(\$ 13,790)$, Windsor Locks $(\$ 13,798)$, Ellington $(\$ 14,063)$,

Manchester $(\$ 14,507)$, Windsor $(\$ 15,121)$, Rocky Hill

$(\$ 15,260)$, and Bolton $(\$ 15,400)$. (See Map 15.)
} 


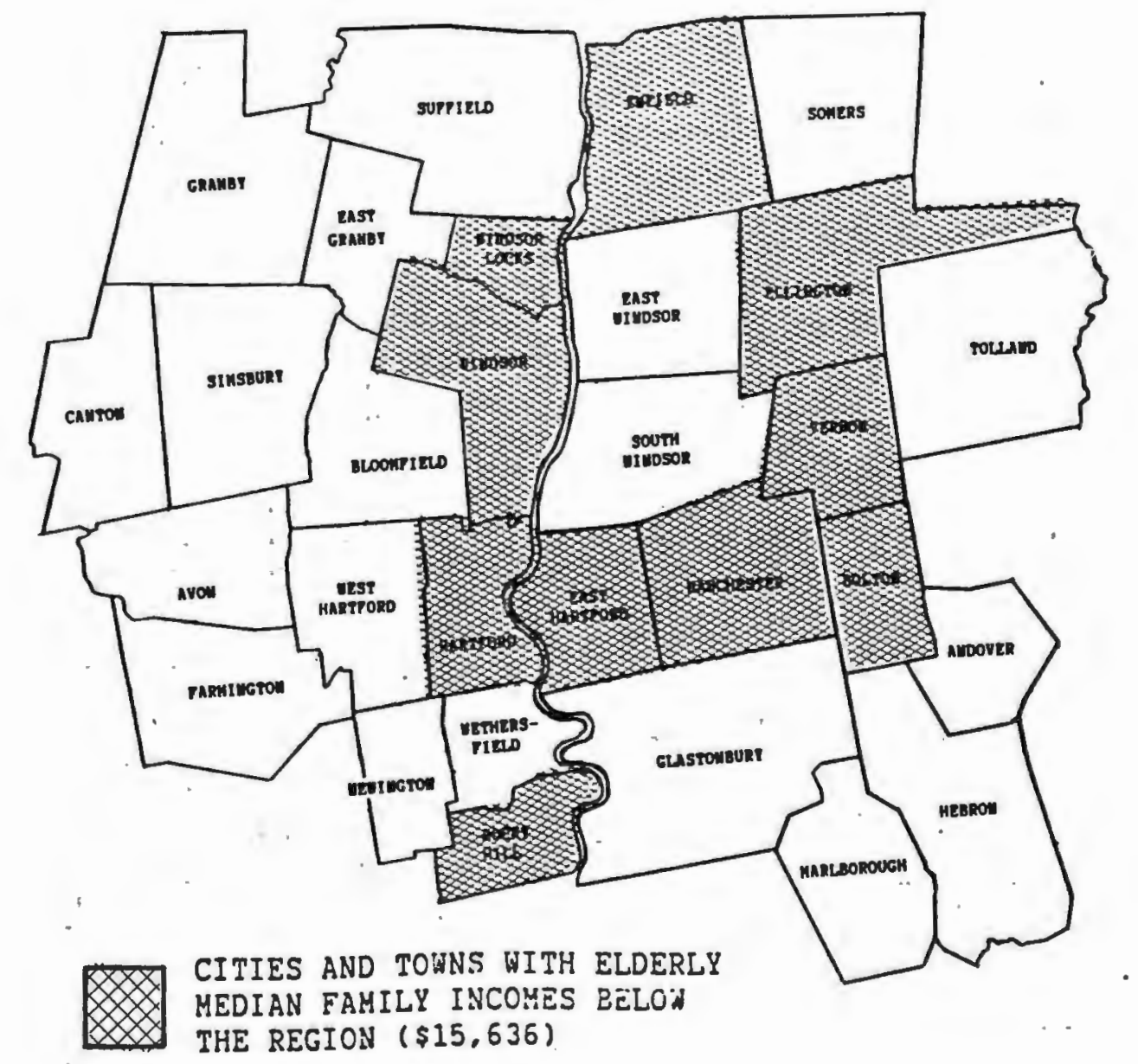

* There were 7 Capitol Region cities and towns with 50\% or more of their elderly families with incomes below $\$ 15,000$. These communities are: Hartford $(60.7 \%)$, Vernon (59.8\%), East Hartford (59.5\%), Windsor Locks (57.3\%), Ellington (50.8\%), Enfield (55.3\%), and Manchester ( $52.5 \%)$. (See Map 16.)

The significance of those elderly families in the Capitol Region with incomes below $\$ 15,000$ is that this income level is approximately the maximum allowable for 2 people to participate in both of the Region's elderly subsidized housing programs. In 1980 


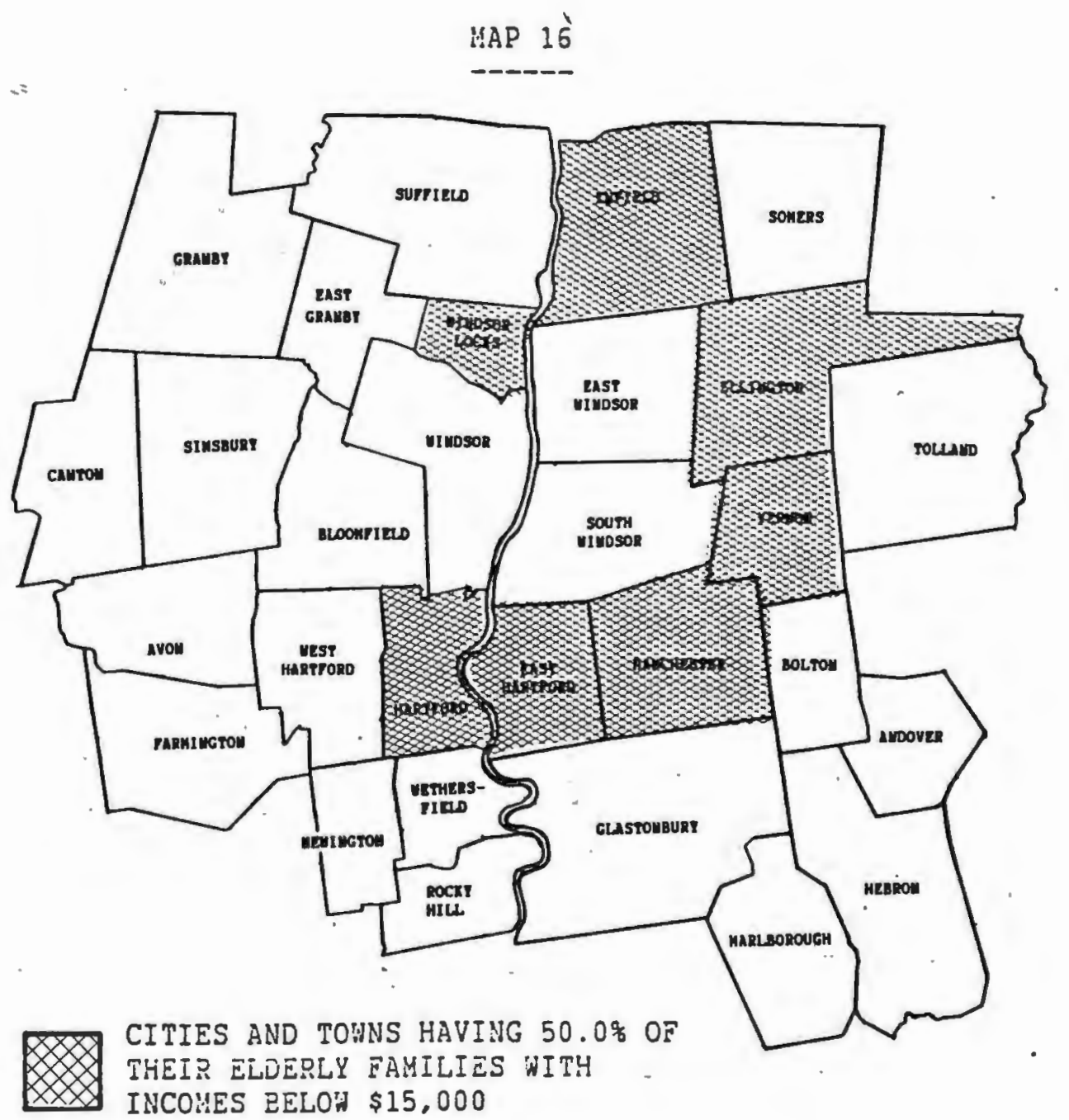

there were 11,859 elderly families (this does not include any single elderly households) who could, by income levels, participate in both subsidized elderly housing programs, but only 9,330 subsidized units were auailable (793 section 8 and 8,537 low and moderate income housing units). It should be noted that inany of these subsidized units are occupied by single elderly households which are not: included in the fanily classification, thereby widening the gap between available subsidized units and elderly families with allowable income levels who could participate in both subsidized housing programs. Therefore, the large number of elderly families with income levels below $\$ 15,000$ illustrates the present need for additional subsidized elderly housing units in the Capitol Region is critical. 


\section{FUTURE NEEDS}

As shown in' previous chapters, the Capitol Region's elderly population will continue to expand. From 1980 to the year 2000 the keyjon's elderly population will grow from 77,018 to 94.733 or $23.0 \%$ (See Table 21). A review of the available data highlights the fact that the present supply of elderly subsidized housing units (Section 8 Rental Assistance and Low and Moderate Incone Housing Developments) does not meet the current demand for these units. As the Capitol Region's elderly population continues to grow, the elderly's need for additional subsidized units becomes more accute. The future demand for elderly units (efficiencies, 1 bedroom units, handicapped units) will be high throughout the entire Region, but highest in those communities which will show large elderly population growth during the years 1985-..2000, and that are currently in short supply of elderly subsidized units (see Table 31). For example, the town of Enfield in 1985 has $4.6 \%$ of the

Capitol Region's elderly but only $3.5 \%$ of the Region's subsidized elderly housing units (excludes Section 8 units in the private housing market). It is projected that over the next 15 years, the town of Enfield's elderly population will grow $71.3 \%$. Unless Enfield builds more subsidized elderly housing units, the demand for these units by the elderly can't help but increase dramatical.y. other capitol Region cities and towns with high (defined as greater than the elderly growth for the Region, which is $12.0 \%$ ) elderly growth rates that currently have a shortage of elderly subsidized units are: Avon, Bolton, Famington, Granby, Hebron, Marlborough, 
TOWN

1985 ELDERLY

SUBSIDIZED

UNITS AS

A \% QF

CAPITOL

ローーー

REGION

ANDOVER

0.3

AVON

0.5

BLDOMF IELD

4.9

BOLTON

0.0

CANTON

1.3

EAST GRANBY

0.8

EAST HARTFQRD

10.4

EAST WINDSOR

1.8

ELLINGTON

ENF IELD

FARMINGTON

GLASTONBURY

GRANBY

HARTFORD

HEBRON

MANCHESTER

1.4

3.5

1.3

3.3

0.4

36.7

0.3

6.2

MARLBOROUGH

0.0

NEWINGTON

2.3

ROCKY HILL

0.5

1.1

SIMSBURY

SOMERS

SOUTH WINDSOR

SUFFIELD

TOLLAND

VERNON

WEST HARTFORD

WETHERSF IELD

WINDSOR

WINDSOR LOCKS

0.6

0.4

1.3

0.4

7.2

5.1

5.5

1.3

1.2

CAPITOL REGION

100.0

1985

TOWNS \%

OF CAPITQL

REGION'S

ELDERLY

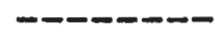

0.2

1.8

3. 6

0.4

0.9

0.4

7.4

1.3

1.0

4.6

2.7

3.2

0.7

18.6

0.4

8.7

0.4

4.7

2.7

2. 4

1.0

0.8

1.4

0.7

3.3

14.7

6.6

3.9

1.6

100.0

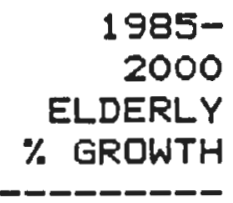

59.9

38.8

13.2

21.4

20.3

41.8

25.6

12.3

38.0

71.3

14.6

35.0

35.2

$-15.2$

78.7

$-7.2$

46.0

10.7

20.6

60.2

59.3

193.3

31.7

104.1

23.9

$-10.8$

$-8.5$

12.0

59.1

12.0

SOURCE: 1984 HOUSING OPPORTUNITIES CRCOG.

Rocky Hill, Simsbury, Somers, South Windsor, Suffield, Tolland, Windsor, and Windsor Locks. (See Map 17 and 18.) It is

conceiveable that Enfield could assurne that those elderly in need could find subsidized housing in other cities and towns within the Region, thereby doing nothing to increase its current supply of low 

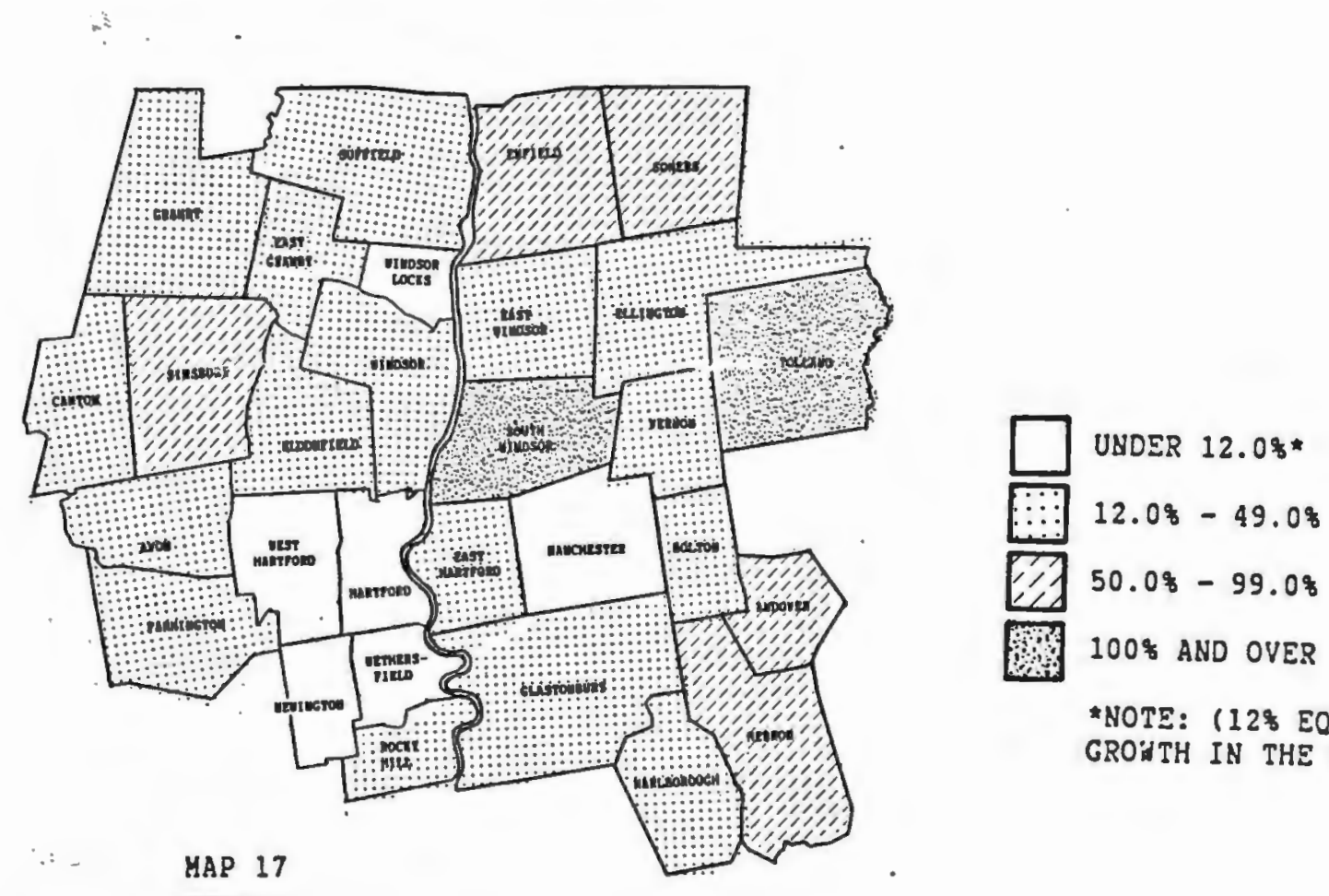

*NOTE: (128 EQUALS THE ELOERLY GROATH IN THE CAPITOL REGION)

ELDERLY POPULATION GROGTH IN

THE CAPITOL REGION (1985-2000)

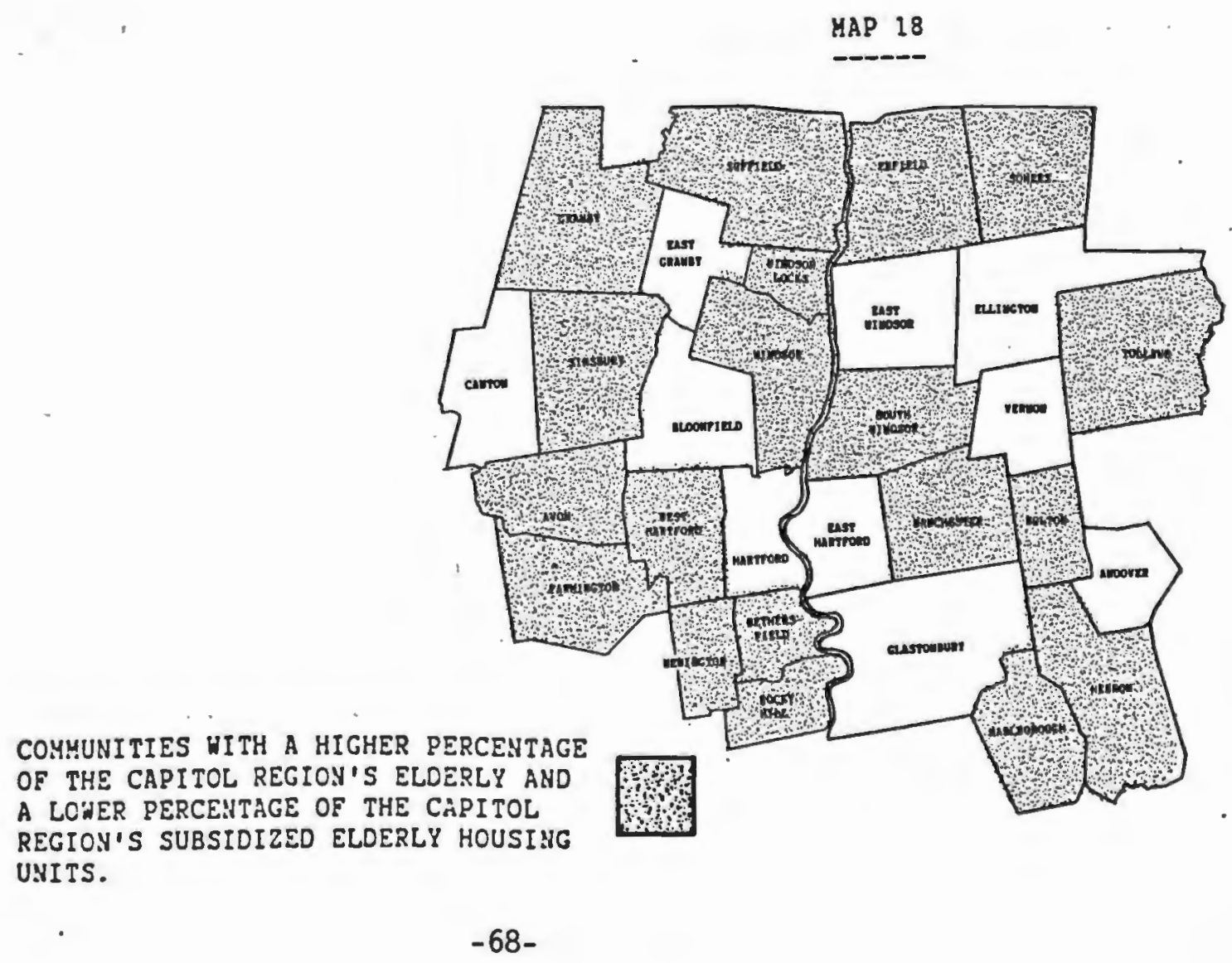


and moderate income housing for the elderly. This brings us to the issue of each community in the future doing its "fair share" in meeting the subsidized housing needs for its own elderly residents. At the present time, most cities and touns are not cloing their "fair share." For example, the city of Hartford shoulders the greatest burden of supplying subsidized housing units to the capitol Region's elderly. As shown in Table 31, in 1985 the city of Hartford contained only $18.6 \%$ of the Region's elderly population but supplied $36.7 \%$ of the Region's subsidjzed elderly housing units (excludes Section 8).

\section{CONCLUSTON}

In conclusion:

* At the present time, the dernand for subsjdized elderly housing units in the capitol Region by far exceeds its supply, with at least one year waiting periods for both elderly subsidized housing programs.

* The number of section 8 rental assistance participants has remained constant, while the number of low and moderate income subsidized housing units being bujlt each year for the elderly is declining.

* There is a large number of elderly individuals in the Capitol Region who are not participating in either subsidized housing program, and consequently reside in substandard housing.

* The Capitol Region contains a large number of elderly families with low income levels that could qualify for the subsidized elderly housing programs but are not participating.

* If the demand for additional subsidized elderly housing units in the capitol Region is not met through the construction of new subsidized units for the elderly, then the current one year period for both subsidized housing programs will increase in the future as the Region's elderly population expands. 
* In the future, the demand for subsidized elderly housing units will be most accute in those Capitol Region communities which show high projected elderly population growth and that are currently in short supply of subsidized elderly housing unjts.

* The burden of prowiding subsidized housing for the elderly should be equaliy apportioned among all the cities and touns within the capitol Region, with each communjty doing its "fair share." 
CONCLUSION 


\section{CONCLIUSION}

In summary, the data presented in this thesis leads one to conclude the Capitol Region is not presently prepared to meet the sizeable dernand for subsidized housing units by the elderly in the future. Therefcrs, unless additional resources are allocated to programs which encourage and promote planned increases in the number of subsidized elderly housing units within the Capitol Region, a housing crisis in the not to distant future is imminent.

There are a number of possible steps which can help to alleviate this impending elderly housing crisis. First, cities and towns within the Capitol Region must treat this potential crisis as a real threat and stimulate the building of new units of subsidized housing for the elderly, possibly through new financing programs or offering incentives to potential developers. This local initiative will become more crucial. as current and projected federal funding cuts in housing subsidies, social security benefits, food stamps, community care, transportation, and other programs for the elderly become a harsh reality. Such cuts in federal spending have in the past, forced very real hardships on the elderly and diminished their ability to afford decent housing. All available data indicates that this trend will. continue well into the future.

Secondly, the Region's communities must exert pressure on their political representatives in both the state and federal capitols, and encourage them to fight for additional funding for elderly housing subsidies and other programs which affect the 
elderly. The fact that the elderly are steadily becoming a larger and more politically vocal group should make the exertion of such pressure an almost natural first step towards achieving this goal. Thirdly, the Capitol Region's cities and towns must reconsider some of the non-traditional methods for increasing the supply of elderly housing as set forth in the 1981 report from the state of Connecticut Department on Aging Task Force. Some method advocated were as follows:

"House Sharing - which involves homeowners who take "boarders" into their home. The owner, the boarder, or both inay be elderly.

Group Homes - where a group of elderly persons live together in a building which they own as a non-profit organization, or which they rent.

$+$

Accessory Apartments - which involves the installation of separate dwelling units in single family homes.

Home Equity Conversion - which covers various financial devices for allowing homeowners to convert the equity in their hoine into income." 7

On the whole, most of these recommendations have not evolved into. any real programs on the local level. Local cominunities must study these options and, where practicable, apply them. 
Fourthly, the Region must do sonething to alleviate high rents: Excessively high rents make it virtually impossible for the Region's elderly, especially those within the section 8 Rental Assistance: Program, to find apartment rents in the priuate housing market that fall within the progran's guidelines. One possible solution may be for those cities and towns to institute a rent: control prograin.

Finally, and most importantly, each city and town within the Capitol Region has an obligation to do its "fair share" in prouiding subsidized housing for the elderly. Without each community acting responsibly, the burden for supplying subsidized elderly housing will fall on a few communities, taxing their already overburden financial resources. Even minimal cooperation in this regard could start them doun the path toward the development and implemention of a fair and equitable elderly housing program from which the entire state will benefit. 
APPENDICES 
The Comprehensive Planning Division, Office of Policy and Management (OPM), in consultation with the connecticut regional planning organizations, has prepared the "1980 connecticut Population Report and Projections to the Year 2000." This report is a revision to the february 1980 publication entitled, "population Projections for Connecticut Municipalities and Regions to the Year 2000." The revision of the 1980 report has been undertaken in order to establish population projections which are consistent with the 1980 Census of Population and Housing.

The figures and projections in this report are based on the 1980 Census counts of population and growth trends in the $1970^{\prime} \mathrm{s}$. These projections should be viewed as modified population trend projection series, rather than as pure trend projections. These projections are not point forecasts, but rather approximations around which future populations may vary. These revisions continue to assume the trends associated with the February 1980 projections based upon assumptions concerning births, deaths, economic activity and migration which are further described below. Also taken into consideration were municipal, regional and state policy actions presently in effect or anticipated for implementation in the near future. The accuracy of the projections will tend to decrease as the projection period lengthens.

The 1982 population projections, with some exception, generally fall below previous projections at the regional and 
municipal levels. The 1980 census figures of connecticut show a population of $3,107,357$, a four (4) percent reduction from the projected figures of the 1980 february report of $3,229,510$. The projected figures through the year 2000 show a similar reduction in population of four (4) percent.

Previous projzitions for the year 2000 all tend to be higher projections when compared to that of the 1980 february report, i.e., The Department of Planning and Energy Policy (DPEP), June 1976 , 3,774,000; U.S. Department of Commerce (OBERS), 1970, 4,000,000; and, projections of the late 1960's indicated over 5,000,000 persons in the year 2000. In July 1981, a revised OBERS series showed a downuard trend in projected year 2000 population for connecticut to 3,527,000, with an indication these projections may further be revised.

The OPM/Comprehensive Planning Division continues to recognize, as reasonable, the assumptions and associated growth trends utilized to develop the February 1980 projection series; however, the 1980 census indicated a need to re-establish the base for population projections from that of the 1970 Census to that of the 1980 census. The population projections with this report, are consistent with the 1980 census of Population and Housing. 
After review of the 1980 Census and past growth trends of the $1970^{\prime}$ 's a deterinination was made by the office of Policy and Managernent to implement an adjustment procedure utilizing the February 1980 projection series based on the 1980 census. This procedure adjusts the projected populatjon of each muncipality to the 1980 Census counts; while maintaining the original, assumed rates of growth or decline in population for each municipality. The adjustinent procedure is applied uniformly to each 5-year interval after 1980 until the year 2000. A cohort-component model was used to develop the preliminary projections used as a basis for the February 1980 population projection series. A "cohort" is defined as age distribution of persons by sex in a particular year. The "components" used were births, deaths and migration. Assumptions were made for these three components by municipality. The number of people in these cohorts are moved from the base year 1970 to the next five-year period 1975 by applying specjtic municipal survival and fertility rates and five-year net migration assumptions which interact within the computer model to change the total number of persons wihin each cohort. This same procedure is followed for each five-year period to the year 2000. The age distribution of the net migrants durjing the projection period was assumed to approximate the 1970-75 period. Town totals were later modified as a result of meeting with regions and municipalities as described in the previous section. 
The objective of this effort is to continue one set of projections that could be used at the municipal, regional and state level for most planning purposes. As a result, a "modified trend" set of population projections is further developed for municipalities in the state for the years 1985, 1990, 1995 and 2000. "Modified traici" population projections are not classic trend projections since, as a result of discussions at the regional and municipal levels, some policy implications have been included in these projections: These include an analysis of persons per household, types of available land, current and future land use, housing development patterns, new transportation facilities and other construction, water and sewer extension, with particular emphasis upon significant current or anticipated revisions in inuncipal zoning.

The future populations shown in the following tables of this report are "modified trend" projections and should not be considered as "planned," "desirable," or "capacity" population levels for the state, municipality or any given region. They are essentially based on a continuation of "slow growth" economy and give significant weight to the dranatic decrease in both births and net in-migration that occurred in connecticut since 1970. As a result, sta.tewide and most municipal and regional figures are significantly lower than previous projections. The projections in this report include all institutional and group quarter populations. 


\section{GENERAL ASSUMPTIONS}

Connecticut's growth rate between 1970 and 1980 was $2.48 \%$.

The 1982 revision of Connecticut's population projections recognizes the slow, steady growth rate in the state in recent years and utilizes the modified trands associated with the February 1980 series of population projections.

Any population projection series depends, largely, upon basic assumptions used regarding future growth and development. While there are significant differences expected in the rate of growth anong the defined planning regions, health seruice areas and muncipalities, there were some general statewide assumptions underlying these projections. They are as follows:

1) Relatively low birth rates will continue during the projection period with births generally near the 1973 level, with a total lifetime fertility rate below 2.0 children per woman.

2) Life expectancy will continue to increase, but at a slower rate during the previous fifteen years with life expectation at birth increasing approximately $21 / 2$ years by the year 2000 .

3) Net in-migration will be significantly lower than during the 1960's but above the level of the 1970's.

4) There will be slow econorric growth during the projection period; out-migration of population from the central cities will level off with some showing slight to moderate increases before the year 2000.

5) Energy costs and commuting distance will be more of a factor in migration and development patterns than during past years with more development occurring along mass transportation corridors. 
The projections in Table 16 were based on the connecticut Department of Health Services 1979 projections for the Capjtol Region. These projections were based on 1979 mortality rates, and late $1970^{\prime}$ s census tronis. Their projections prior to the release of the 1980 Census were fairly accurate. The 1979 projections showed the Capitol Region having a 1980 total population of 097,111 persons, with 74,584 persons 65 years of age or older. When compared to the actual 1980 Census figures, one finds the Capitol Region's total population to be slightly lower than the 1979 projections (1980-008,479 persons, a $1.2 \%$ discrepancy), and the Capitol Region's actual 1980 elderly population to be slightly greater ( $1980-77,018$ persons $65+$, a $3.2 \%$ discrepancy) than the 1979 projections. Since the 1979 Health Services projections were fairly accurate in relation to the actual 1980 figures, their projections were used as a basis for Table 16 and then adjusted. In order to obtain the Capitol. Region's elderly population for the years 1985 , 1990, 1995 and 2000, the 1979 projections were adjusted by $3.2 \%$. This percentage represents the difference between the 1979 projections and the actual 198065 years and older population. 
The projections in Table 21, were based on the connecticut Department of Health Services 1979 projections for the Capitol Region. These projections were based on 1979 mortality rates, and late 1970's census trands. Using the methodology described in Appendix B these projections were adjusted to reflect the actual 1980 census data. At the present time the data presented in Table 21 is the best available. 
1 Kenneth Hadden, College of Agriculture and Natural Resources, University of Connecticut, Storrs, CT. Bulletin 421, April 1973 The Population of Connecticut, 1970: Age and Sex Composition. p. 6 .

2 ibid., p.6.

3 Joyce E. Aparo, Richard J. Gruber, Nancy J, Budds, Bureau of Health Planning and Resource Allocation, State of connecticut Department of Health Services. Profile of Connecticut's Current and Future Elderly: Briefing Paper one. Sept. 1981 . p. 3.

4 ibid., p.2.

5 State of Connecticut Department of Housing. Annual Housing Report (Hartford, CT.: March, 1983), p. 49.

6 ibid., p. 44.

7 State of Connecticut Department on Aging, 1981 Annual Report (Hartford, CT.: August, 1981), p. 28. 
Aparo, Joyce E: Richard J. Gruber, Nancy J. Budds. "Profile of Connecticut Current and Future Elderly: Briefing Paper One." Bureau of Health Planning and Resource Allocation, State of Connecticut Department of Health Services. Hartford, CT: Sept. 1981, pp. 1-3.

Capjtol Region Council of Governments. Census Data Summary of the Capitol Region 1960-1970-1980. Hartford, CT.: June 1982.

1983 Housing Opportunities. Hartford, CT.:

Decernber 1983, pp. 18-20.

1984 Housing Opportunities. Hartford, CT.:

Decernber 1984, pp. 18-30.

Hadden, Kenneth. "Bulletin 421, The Population of Connecticut, 1970: Age and Sex Composition." College of Agriculture and Natural Resources, University of connecticut. Storrs, CT.: April, 1973, pp. 6 .

State of Connecticut Department on Aging. 1981 Annual Report. Hartford, CT.: August 1981 , pp. 28.

State of Connecticut Department of Health Services. Bulletin HET 1528C. Hartford, CT.: March 1979.

State of Connecticut Department of Housing. Annual Housing Report. Hartford, CT.: March 1983, pp. 49.

Survey of Housing Authorities. Hartford, CT.: 1983.

State of Connecticut office of Policy and Management, Comprehensive Planning Divison. Population Projections for Connecticut Municipalities and Regions to the Year 2000. Hartford, CT.: June 1982.

State of Connecticut office of Policy and Management, connecticut Census Data Center. Memorandum No. 5 Age, Sex, Race and Spanish Origin of the Population by Regions, Divisions, and state: 1980 Hartford, CT.: May 1981.

U.S. Department of Commerce, Bureau of the census. Housing Count Files, Suminary Tape File No. 4. Washington, D.C. 1980.

. Connecticut's General Population Characteristics. Washingtoon D.C.: $1900-1980$. 
Congressional Research Service. The Impact of Federal Housing Programs on the Elderly. (CRS ReP. NO. 79-176E). Congressional Research Service, Economics Divison, Library of Congress. Washington, D.C.

Ferree, G. Donald, Jr. Needs Assessment of Connecticut's Elderly population Survey conducted for the connecticut Department on Aging. University of Connecticut, Institute for Social Inquiry. August, 1981 .

Housing Coalition for the Capitol Region. Town by Town Housing. Survey. Hartford, CT.: Suminer 1981.

Robey, Bryant. "Age in America." American Demographics. Ithaca, N.Y.: August 1981 , Pp. 14-19.

Roudebush, Janice; Leslie J. Wells. "Low and Moderate Income Housing: Part 1 Increasing the Supply and Accessibility." American Planning Association, Planning Aduisory Service; Report No. 350. Chicago, II. 1980.

State of Connecticut Department on Aging. The Elderly Population in Connecticut: A Fact Sheet. Hartford, CT.: January 1982 .

- Innovative Options in Elderly Housing: A Manual for Local Action. Hartford, CT.: February 1982 .

U.S. Congress. House. Alternative Housing options for the Elderly. Hearing before the sub-committee on Housing and Consumer Interest. 9oth Congress. 2nd Session. October 1980.

U.S. Department of Housing and Urban Development. Prograins of HUD. Washington, D.C. 